CAROLINA GIL GARCIA

\title{
REATOR TERMOFILICO ACIDOGÊNICO/SULFETOGÊNICO SEGUIDO DE REATOR METANOGÊNICO PARA TRATAMENTO DE ÁGUA RESIDUÁRIA RICA EM SULFATO
}

Tese apresentada à Escola de Engenharia de São Carlos, da Universidade de São Paulo, como parte dos requisitos para obtenção de título de Doutor em Ciências: Engenharia Hidráulica e Saneamento.

Orientadora: Prof ${ }^{a}$. Dra. Márcia Helena Rissato Zamariolli Damianovic

VERSÃO CORRIGIDA

SÃO CARLOS 
AUTORIZO A REPRODUÇÃO TOTAL OU PARCIAL DESTE TRABALHO, POR QUALQUER MEIO CONVENCIONAL OU ELETRONIICO, PARA FINS DE ESTUDO E PESQUISA, DESDE QUE CITADA A FONTE.

Ficha catalográfica elaborada pela Biblioteca Prof. Dr. Sérgio Rodrigues Fontes da EESC/USP com os dados inseridos pelo(a) autor(a).

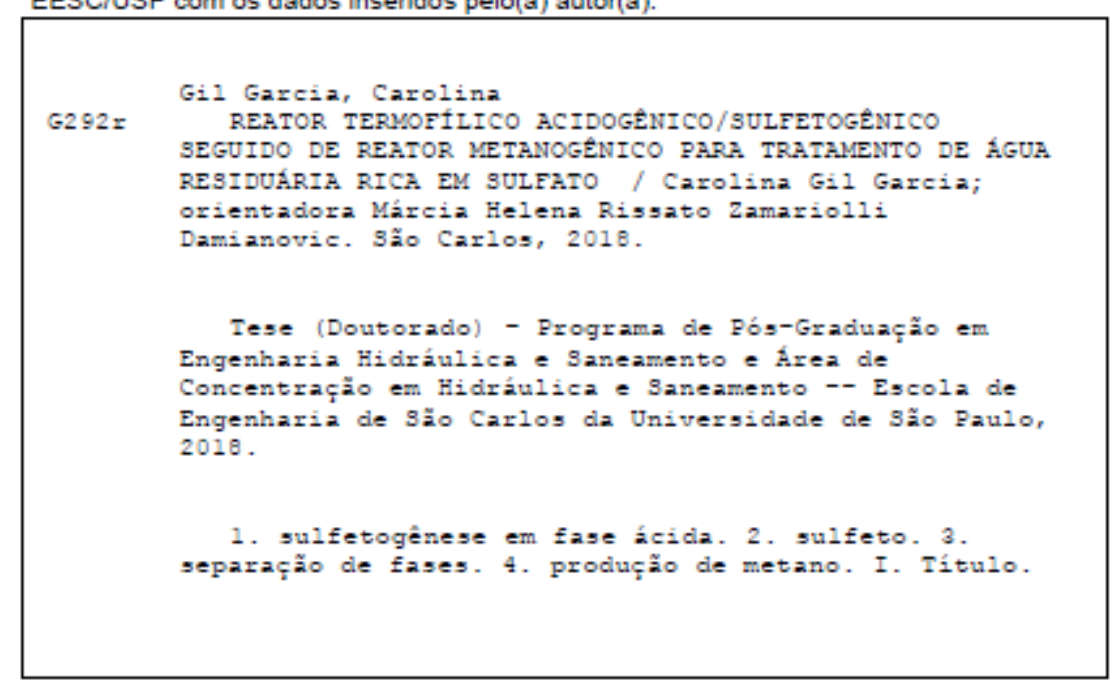

Eduardo Graziosi Silva - CRB - 8/8907 


\section{FOLHA DE JULGAMENTO}

Candidata: Bacharel CAROLINA GIL GARCIA.

Título da tese: 'Reator termofilico acidogénico/sulfetogênico seguido de reator metanogênico para fralamento de água residuária rica em sulfato".

Data da defesa: 11/05/2018.

Comissāo Julgadora:

Resultado:

Profa. Dra. Máncia Helena Rissato Zamariolli Damianovic

(Orientadora)

(Escola de Engenharia de São Carlos/EESC)

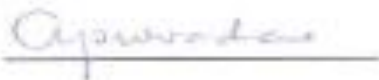

Prof. Titular Marcelo Zaiat

(Escola de Engenharia de Sāo Carlos/EESC)

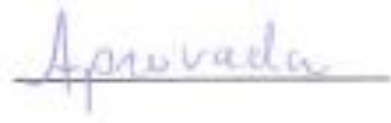

Profa. Dra. Flávia Talarico Saia

(Universidade Federal de São Paulo/UNIFESP-Santos)

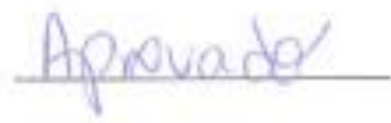

Prof. Dr. Theo Syrto Octavio de Souza

(Escola Politécnica/EP-USP)

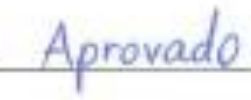

Profa. Dra. Ana Cláudia Barana

APRONARO

(Universidade Estadual de Ponta Grossa/UEPG)

Coordenador do Programa de Pós-Graduação em Engenharia Hidráulica e Saneamento:

Prof. Dr. Eduardo Mario Mendiondo

Presidente da Comissão de Pós-Graduação:

Prot. Associado Luis Fernando Costa Alberto 

Aos meus pais, Silvia e Sérgio, meus exemplos de vida. 



\section{AGRADECIMENTOS}

A Deus, por ter concedido a vida e sempre iluminado meu caminho.

Aos meus pais, Silvia e Sérgio, grandes mestres, responsáveis por me ensinarem os grandes valores da vida, ao apoio nas decisões e sempre prontos para me acolherem. Sem vocês, com certeza isso tudo não seria possível.

Ao meu irmão Caio, grande exemplo de garra, parceria e bom humor.

Ao Henrique, pelo carinho, apoio, paciência (ainda mais nessa reta final!) e principalmente, companheirismo.

À Família Fernandes, Ana, Valdir e Luan por me receberem de braços abertos.

A minha orientadora Márcia Damianovic, a quem eu tenho total admiração pela profissional, professora, orientadora, pesquisadora, que me acolheu e deu todo o suporte e atenção durante toda essa caminhada. Respeito também pela mulher guerreira, cuidadosa e sempre muito preocupada com os “orientados/filhos”, nossa Mãezona do LPB.

Aos "chefes", professores Eugênio Foresti, Marcelo Zaiat, Maria Bernadete Varesche e Wiclef Marra, por todo o convívio, sempre dispostos a nos ajudar no que fosse preciso, pela animação nos cafezinhos e confraternizações. Tenho muita sorte de ter trabalhado dentro de um grupo com os grandes nomes do saneamento.

Aos "Panquecudos", que transformam os 7 x 1 do dia-a-dia em piada e muita zueira! A rotina de laboratório ficou muito mais divertida com a amizade de vocês. A dupla dinâmica Leandro e Lucas, que entre uma DQO e um sulfetinho, surgia o momento de longas discussões acadêmicas e no final ainda havia tempo para levar uns sustos. Priscila longas conversar, conselhos, sessões de análise e irmãzinha de sulfeto. Palladino, o cara pacato e salvador da biomol. Rachel, a amiga com cara de brava, mas com um coração enorme. Eduardo, mais conhecido como Google, com todas as respostas na ponta da língua e lista de indicações na mão. Isabella, nossa consultora pet. Natália, a mamis dos Panquecudos, da princesa Helena (nossa baby) e a Panks.

A "Casa da mãe Camila", Camila e Marcim que abriram as portas da casa e adotaram mais três pentelhas: Lais Américo, Carla e eu! Sempre muito bom passar longas horas papeando ao redor daquele fogão à lenha. Mamis Camily, sempre preocupada com "as crianças", às vezes 
dá uns puxões de orelha (normal né). Carla, nossa "ursinha carinhosa", compreensiva e disposta a ajudar. Laís Américo (aowww Osasco), de coração gelado pra manteiga derretida, amoleceu esse coraçãozinho. Não poderia deixar de fora os pimpolhos: Maria Clara, Samuel e Bernardo.

Às "Cabritas", Cristiane, minha vizinha de câmara, parceira de vazamentos e de "aiii meu Deus, não sei mais o que faço com esses reatores!”. Mirabelle, outra irmãzinha do sulfeto, duplinha de gordices (não são poucas). E no final de tudo, sempre acabava com a "caça às blusinhas".

À Carolzinha (Tchuca), que mesmo a distância eu consigo atormentar. E não é que deu certo essa amizade! E já se foram mais de 10 anos de parceria, risadas, choradeiras, rangos que se resumiam em creme de milho e cachorro quente (aooooo vida universitária), inúmeras "nejas" e acima de tudo, um amor incondicional por essa irmã que a vida me deu.

À Gabriela (Laila), pelas longas conversas, os momentos de nostalgia iratiense, rolezinhos e os diversos "causos".

À Jéssica Nardo, amiga que a vida uniu nos tempos da Escola Leonardo e que tenho total admiração. Obrigada pelos longos papos, muita risada, troca de receitinhas e infinitos conselhos!

A família que São Carlos me proporcionou, desde a época do mestrado: Ana Paula, Andressa (Dé), Araceli (muié viajadeira), Elias, Fernanda, Jairo, Jamil, Juliana Nóbrega, Karen, Laís Giraldi, Lívia Ottaviano, Matheus (caçador de onça), Paulo (Pauleta, o cara do mineirês), Tácyo, Tiago (Cebola, contador de causo).

Aos amigos de São Roque: Alessandra, Fernanda, Jones, Thiago (Romário), Thiago (Canguera), que fazem dos raros encontros, grandes encontros.

À Roseta e agregados, Carlos, Alessandro, Daniele, Augusto, Érica, Denise, Thiago por animarem às reuniões de sexta.

Aos companheiros do LPB, Adriana, Adriano, Alana, Alexandra, Ania, Bruna, Bruno Giz, Dagoberto, Fabricio (e a Vó também, por fornecer aquele brigadeiro maravilhoso pra galera), Fiaz, Guilherme Oliveira (GHDO, nosso eterno tira-dúvida), Guilherme Soares, Guilherme Vuitik, Inaê, Leonardo (Sr. Léo), Lívia Botta, Luma, Mara Rúbia, Maritza, Miriam (não pótiiii), Moara, Murilo, Pâmela Castilho, Pamela Couto, Paulo, Pilar, Raissa, Raphaella, 
Rodrigo Carneiro (Béee), Rogério, Simone, Tainá, Tania, Thaís, Theo (a lousa branca nunca mais foi a mesma), Thiago (IQSC), Tiagão (o cara animado) Valéria, Vanessa, Vivian.

Às Mãezonas do LPB, Ana Flávia, Inês, Renata, que no meio da correria, davam um jeitinho de acolher a galera, com palavras de conforto, um ombro amigo, agrados e comidinhas gostosas.

À equipe técnica do LPB: Carolina Sabatini, Eloiza Pozzi, Fernando Moura, Isabel Sakamoto, Maria Angela Adorno (Janja) e Silvana Celestini por todo o suporte e ajuda ao longo de todos esses anos de LPB.

Ao Conselho Nacional de Desenvolvimento Científico e Tecnológico (CNPq), processo 161940/2015-3, a Coordenação de Aperfeiçoamento de Pessoal de Nível Superior (CAPES), processo 1405116 e a Fundação de Amparo à Pesquisa do Estado de São Paulo (FAPESP), processo 2009/15984-0 e 2015/06246-7, pelo fornecimento de bolsa e auxílio financeiro complementar para a realização da pesquisa. 

"A tarefa não é tanto ver aquilo que ninguém viu, mas pensar o que ninguém ainda pensou sobre aquilo que todo mundo vê." Arthur Schopenhauer 



\section{RESUMO}

\section{GARCIA, C.G (2018). Reator termofílico acidogênico/sulfetogênico seguido de reator}

metanogênico para tratamento de água residuária rica em sulfato (Tese de Doutorado) -

Departamento de Hidráulica e Saneamento, Universidade de São Paulo, São Carlos.

O tratamento de água residuária rica em sulfato por via de processo anaeróbio é um grande desafio, devido ao potencial de redução do sulfato pela via biológica a sulfeto, o que pode inviabilizar o aproveitamento do biogás e afetar o tratamento por seus efeitos tóxicos e inibitórios. Neste contexto, o presente trabalho investigou a potencial aplicação da separação de fase para minimizar tais problemas de operação. A operação de reator de primeira fase visa estabelecer um ambiente sulfetogênico sob condições acidogênicas. Os efeitos da préacidificação da água residuária sobre a produção de metano foram avaliados por meio do monitoramento de dois reatores metanogênicos, um sistema de fase única alimentado com água residuária rica em sulfato e um sistema de duas fases alimentado com água residuária acidificada. Em todos os casos foram utilizados reatores anaeróbios de leito estruturado, aplicada condições termofílica de temperatura $\left(55^{\circ} \mathrm{C}\right)$. Para o sistema de primeira fase, dois reatores com diferentes materiais foram comparados: reator com cilindros de polietileno de baixa densidade ( $\mathrm{R}_{\mathrm{AS} \text {-PEBD }}$ ) com cinco etapas de operação (13 subetapas) e outro reator com cubos de espuma de poliuretano ( $\left.\mathrm{R}_{\mathrm{AS}-\mathrm{PU}}\right)$ com quatro etapas de operação. As principais estratégias operacionais para otimização da redução do sulfato a variação do tempo de detenção hidráulica (TDH: 6-15 h - $\mathrm{R}_{\mathrm{AS}-\mathrm{PEBD}}$; 12 - 16 h - $\mathrm{R}_{\mathrm{AS}-\mathrm{PU}}$ ), carga orgânica volumétrica $\left(\mathrm{COV}_{\mathrm{afl}}: 10-20,0 \mathrm{~kg}-\mathrm{DQO} \mathrm{m}^{-3} \mathrm{~d}^{-1}-\mathrm{R}_{\mathrm{AS}-\mathrm{PEBD}} ; 15-20 \mathrm{~kg}-\mathrm{DQO} \mathrm{m}^{-3} \mathrm{~d}^{-1}-\mathrm{R}_{\mathrm{AS}-\mathrm{PU}}\right)$, carga de sulfato volumétrica (CSV: $3,2-16,0 \mathrm{~kg}_{-} \mathrm{SO}_{4} \mathrm{~m}^{-3} \mathrm{~d}^{-1}-\mathrm{R}_{\mathrm{AS}-\mathrm{PEBD}} ; 4-8 \mathrm{~kg}-\mathrm{SO}_{4} \mathrm{~m}^{-3} \mathrm{~d}^{-1}-\mathrm{R}_{\mathrm{AS}-\mathrm{PU}}$ ) e velocidade ascensional $\left(\mathrm{V}_{\mathrm{a}}\right.$ : $\left.0,06-3,35 \mathrm{~m} \mathrm{~h}^{-1}-\mathrm{R}_{\mathrm{AS}-\mathrm{PEBD}} ; 3,42-7,9 \mathrm{~m} \mathrm{~h}^{-1}-\mathrm{R}_{\mathrm{AS}-\mathrm{PU}}\right)$. Após longo período de adaptação da biomassa no $\mathrm{R}_{\mathrm{AS}-\mathrm{PEBD}}$, verificou-se o aumento da eficiência e stripping do sulfeto. A recirculação controlada do efluente foi um fator chave para melhoria do sistema. $\mathrm{O}$ mesmo não foi obtido em $\mathrm{R}_{\mathrm{AS}-\mathrm{PU}}$, apresentando perda de desempenho devido a problemas de colmatação e subsequente aparecimento de vias preferenciais. O efluente do reator de primeira fase com carga de sulfato residual menor que 7\% (COVefl de 15,12 kgDQO $\mathrm{m}^{-3} \mathrm{~d}^{-1}$ e sulfeto de $256 \mathrm{mg} \mathrm{L}^{-1}$, subetapa X) foi aplicado em reator metanogênico de segunda fase $\left(\mathrm{R}_{\mathrm{MI}}\right)$. Considerando a comparação entre os sistemas metanogênicos, fixou-se uma carga orgânica (CO) inicial de 2,5 g-DQO d-1, sendo aumentada até $5 \mathrm{~g} \mathrm{~d}^{-1}$. A partida do reator de fase única apresentou limitações, requerendo aplicação de baixos valores de $\mathrm{CO}$, o que demandou 140 dias até a estabilização para a carga de $5 \mathrm{~g}$-DQO d ${ }^{-1}$. Por sua vez, o sistema com duas fases necessitou de 102 dias e apresentou maior geração de metano $\left(\mathrm{R}_{\mathrm{MI}}\right.$ $1,95 \mathrm{~L}_{-} \mathrm{CH}_{4} \mathrm{~d}^{-1}$ e $\left.\mathrm{R}_{\mathrm{MII}} 1,76 \mathrm{~L}_{-} \mathrm{CH}_{4} \mathrm{~d}^{-1}\right)$. A separação de fases permitiu a geração de efluente acidificado com menores concentrações de sulfato residual, resultando em maior produção de metano e reduzida concentração de sulfeto no biogás no sistema de duas fases, quando comparado ao sistema de fase única.

Palavras-chave: Sulfetogênese em fase ácida, sulfeto, separação de fases, produção de metano. 



\begin{abstract}
GARCIA, C.G (2018). Thermophilic acidogenic/sulfidogenic reactor followed by methanogenic reactor to treat sulfate-rich wastewater (Tese de Doutorado) -

Departamento de Hidráulica e Saneamento, Universidade de São Paulo, São Carlos.
\end{abstract}

The treatment of sulfate-rich wastewater via anaerobic processes is challenging, due to the potential biological sulfate reduction to sulfide, which limits biogas use and affect treatment performance due to toxic and inhibitory effects. In this context, this study investigated the potential application of phase separation to minimize such operating problems. The operation of the first-stage reactor aimed to establish a sulfidogenic environment under acidogenic conditions. The effects of pre-acidifying the wastewater over methane production was further assessed through monitoring two methanogenic reactors, i.e., one single-phased system fed with raw sulfate-rich wastewater and one two-phased system fed with acidified wastewater. In all cases anaerobic structured-bed reactors were used as well as thermophilic temperature conditions were applied $\left(55^{\circ} \mathrm{C}\right)$. For the first-phase system, two reactors with different materials were compared: reactor with low density polyethylene cylinders $\left(\mathrm{R}_{\mathrm{AS}-\mathrm{PEBD}}\right)$ with five operating steps (13 sub-stages) and another reactor with polyurethane foam cubes (RAS-PU) with four operating steps. The main operational strategies for the optimization of sulfate reduction were the variation of hydraulic retention time (HRT: 6-15 $\mathrm{h}-\mathrm{R}_{\mathrm{AS}-\mathrm{PEBD}} ; 12-16 \mathrm{~h}-$

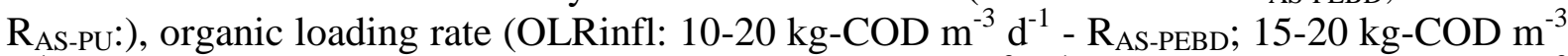
$\mathrm{d}^{-1}-\mathrm{R}_{\mathrm{AS}-\mathrm{PU}}$ ), sulfate loading rate (SLR: 3.2-16.0 kg-SO $\mathrm{m}^{-3} \mathrm{~d}^{-1}-\mathrm{R}_{\mathrm{AS}-\mathrm{PEBD}} ; 4-8 \mathrm{~kg}_{-} \mathrm{SO}_{4} \mathrm{~m}^{-3}$ $\left.\mathrm{d}^{-1} \quad \mathrm{R}_{\mathrm{AS}-\mathrm{PU}}\right)$, and upflow velocity $\left(\mathrm{V}_{\mathrm{u}}: 0.06-3.35 \mathrm{~m} \mathrm{~h}^{-1}-\mathrm{R}_{\mathrm{AS}-\mathrm{PEBD}} ; 3.42-7.9 \mathrm{~m} \mathrm{~h}^{-1}-\mathrm{R}_{\mathrm{AS}-\mathrm{PU}}\right)$. After a long period of biomass adaptation in $\mathrm{R}_{\mathrm{AS}-\mathrm{PEBD}}$, increasing efficiency patterns and sulfide stripping were observed. Controlling effluent recirculation was the key-factor to improve system performance. The same pattern was not obtained in $\mathrm{R}_{\mathrm{AS}-\mathrm{PU}}$, which presented performance losses due to clogging-related problems and the subsequent establishment of preferential pathways. The effluent from the first-phase reactor with residual sulfate load rate of less than $7 \%\left(\mathrm{OLR}_{\mathrm{efl}}\right.$ of $15.12 \mathrm{~kg} \mathrm{~m}^{-3} \mathrm{~d}^{-1}$ and sulfide of $256 \mathrm{mg} \mathrm{L}^{-1}$, sub-step X) was applied to a second-phase methanogenic reactor. Considering the comparison between the methanogenic systems, an initial organic load (OL) of $2.5 \mathrm{~g}-\mathrm{COD} \mathrm{d}{ }^{-1}$ was set, which was further increased up to $5 \mathrm{~g} \mathrm{~d}^{-1}$. The start-up of the single-phase reactor presented limitations, requiring the application of lower OL values, in order to require 140 days up to the stabilization of the load of $5 \mathrm{~g}$-COD d ${ }^{-1}$. In turn, the two-phase system required 102 days and presented higher methane generation rates metano $\left(\mathrm{R}_{\mathrm{MI}} 1,95 \mathrm{~L}-\mathrm{CH}_{4} \mathrm{~d}^{-1}\right.$ and $\mathrm{R}_{\mathrm{MII}} 1,76 \mathrm{~L}-\mathrm{CH}_{4}$ $\mathrm{d}^{-1}$ ). Phase separation enabled the generation of an acidified effluent with lower residual sulfate concentrations, leading to higher methane production and low sulfide concentration in the biogas in the two-phase system, when compared to the single phase system.

Keywords: Sulfidogenese in acid phase, sulfide, phase separation, methane production 



\section{LISTA DE FIGURAS}

FIGURA 1 - Esquema da digestão anaeróbia, incluindo as principais rotas (hidrólise, acidogênese, acetogênese, metanogênese e sulfetogênese). $(\longrightarrow$ metanogênese e ( - - ) sulfetogênese.

FIGURA 2 - Especiação do sulfeto em diferentes valores de $\mathrm{pH}$ à $30^{\circ} \mathrm{C}$ : faixa de $\mathrm{pH}$ da digestão anaeróbia, pH ótimo para metanogênese.

FIGURA 3 - Representação esquemática do aparato experimental utilizado na fase acidogênica/sulfetogênica: 1- reservatório de efluente sintético, 2 - bomba peristáltica para alimentação, 3 - câmara de entrada do afluente, 4 - região reacional (leito estruturado - (a) material suporte em PEBD; (b) material suporte em PU, 5- amostradores (A-E), 6 - linha de recirculação, 7 - bomba dosadora para recirculação, 8 - câmara de saída do efluente, 9 septo para amostragem da fase líquida, 10 - saída do efluente, 11 - saída do biogás, 12 selo hídrico, 13 - medidor de gás.

FIGURA 4 - Vista superior do material suporte no reator: (a) Cilindros de polietileno de baixa densidade (PEBD)- $R_{A S I}$; (b) Cubos de espuma de poliuretano (PU)- $R_{A S I I}$..............

FIGURA 5 - Fluxograma geral das condições operacionais aplicadas ao reator acidogênico/sulfetogênico utilizando PEBD como material suporte, tendo como principais variáveis acarga de sulfato volumétrica $(C S V)$, velocidade ascensional $\left(V_{a}\right)$ e carga orgânica volumétrica $(\mathrm{COV})$

FIGURA 6 - Representação esquemática do aparato experimental utilizado na fase metanogênica: 1- reservatório de efluente sintético, 2 - bomba peristáltica para alimentação, 3 - câmara de entrada do afluente, 4 - região reacional (leito estruturado), 5- amostradores (A-E), 6 - câmara de saída do efluente, 7 - septo para amostragem da fase líquida, 8 - saída do efluente, 9 - saída do biogás, 10 - selo hídrico.

FIGURA 7 - Fluxograma de tratamento do presente trabalho, contemplando os reatores acidogênicos/sulfetogênico de primeira fase $\left(R_{A S-P E B D}\right.$ e $\left.R_{A S-P U}\right)$ e os reatores metanogênico de segunda fase $\left(R_{M I}\right)$ e de fase única $\left(R_{M I I}\right)$.

FIGURA 8 - Resultados operacionais referentes à etapa 1 do reator acidogênico/sulfetogênico com PEBD como material suporte PEBD (a) Carga orgânica volumétrica removida; (b) Carga de sulfato volumétrica removida; (c) Sulfeto; (d) Ácidos voláteis totais......

FIGURA 9 - Resultados operacionais referentes à etapa 2 do reator acidogênico/sulfetogênico com PEBD como material suporte PEBD (a) Carga orgânica volumétrica removida; (b) Carga de sulfato volumétrica removida; (c) Sulfeto; (d) Ácidos voláteis totais. 
FIGURA 10 - Concentração de sulfeto dissolvido $\left(\mathrm{H}_{2} \mathrm{~S}\right.$ e $\left.H \mathrm{~S}^{-}\right)$e pH ao longo da altura do $\mathrm{R}_{A S-}$ PEBD nas subetapas operacionais selecionadas: (a) $V$ (taxa de recirculação $=38,0),(b) V I$ (taxa de recirculação $=57,0)$ e c) VII (taxa de recirculação $=0,0)$.

FIGURA 11 - Resultados operacionais referentes à etapa 3 do reator acidogênico/sulfetogênico com PEBD como material suporte PEBD (a) Carga orgânica volumétrica removida; (b) Carga de sulfato volumétrica removida; (c) Sulfeto; (d) Ácidos voláteis totais. 54

FIGURA 12 - Resultados operacionais referentes à etapa 4 do reator acidogênico/sulfetogênico com PEBD como material suporte PEBD (a) Carga orgânica volumétrica removida; (b) Carga de sulfato volumétrica removida; (c) Sulfeto; (d) Ácidos voláteis totais 58

FIGURA 13 - Resultados operacionais referentes às 5 etapas do reator acidogênico/sulfetogênico com PEBD como material suporte PEBD (a) Carga orgânica volumétrica removida; (b) Carga de sulfato volumétrica removida; (c) Sulfeto; (d) Ácidos voláteis totais. 60

FIGURA 14 - Composição do biogás gerado no reator ASTBR com PEBD 62

FIGURA 15 - Sulfeto estimado $\left(\mathrm{H}_{2} \mathrm{~S}+\mathrm{HS} \mathrm{S}^{-}\right)$e acumulado na fase líquida de acordo com cada fase operacional do reator acidogênico/sulfetogênico de PEBD. Nota: Calculo da produção de sulfeto teórico assumindo que $1 \mathrm{~g}$ de $\mathrm{SO}_{4}{ }^{2-}$ reduzido produz $0,33 \mathrm{~g}$ de sulfeto total. 65

FIGURA 16 - Sulfeto estimado $\left(\mathrm{H}_{2} \mathrm{~S}+\mathrm{HS}\right.$-) e acumulado na fase líquida de acordo com cada fase operacional do reator acidogênico/sulfetogênico de PU. Nota: Calculo da produção de sulfeto teórico assumindo que $1 \mathrm{~g}$ de $\mathrm{SO}_{4}{ }^{2-}$ reduzido produz $0,33 \mathrm{~g}$ de sulfeto total. 68

FIGURA 17 - Resultados operacionais referentes ao reator acidogênico/sulfetogênico de PU (a) Carga orgânica volumétrica removida; (b) Carga de sulfato volumétrica removida; (c) Sulfeto; (d) Ácidos voláteis totais

FIGURA 18 - Composição do biogás produzido no reator acidogênico/sulfetogênico com poliuretano como material suporte $\left(R_{A S-P U}\right)$. 71

FIGURA 19 - Composição do leito estruturado composto por cubos de espuma de poliuretano do reator acidogênico/sulfetogênico $\left(R_{A S-P U}\right)$ ao final da operação das quatro etapas..... 72

FIGURA 20 - Comparação entre a produção diária de metano (boxplot) entre os reatores de segunda fase $\left(R_{M I}\right)$ e fase única $\left(R_{M I I}\right)$ relacionada com a carga orgânica (- - -)..... 75

FIGURA 21 - Composição do biogás nos reatores metanogênicos de segunda fase (RMI) de fase única (RMII) durante a operação com carga orgânica de $5 \mathrm{~g} \mathrm{~d}^{-1}$..... 77 


\section{LISTA DE TABELAS}

Tabela 1 - Reações de redução do sulfato e produção de metano a partir de diferentes doadores de elétrons.....

Tabela 2 - Parâmetros operacionais aplicados ao reator acidogênico/sulfetogênico com PEBD como material suporte $\left(R_{A S-P E B D}\right)$.

Tabela 3 - Parâmetros operacionais aplicados ao reator acidogênico/sulfetogênico de poliuretano

Tabela 4 - Condições operacionais para o reator metanogênico de segunda fase $\left(R_{M I}\right)$.........33

Tabela 5 - Condições operacionais para o reator de fase única $\left(R_{\text {MII }}\right)$.................................. 34

Tabela 6 - Solução estoque para preparo de água residuária sintética ................................... 36

Tabela 7 - Água residuária sintética para o reator acidogênico/sulfetogênico com PEBD

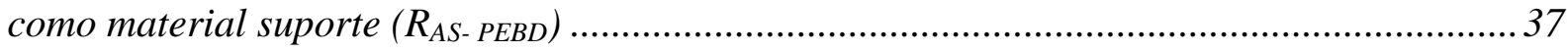

Tabela 8 - Água residuária sintética para o reator acidogênico/sulfetogênico com material

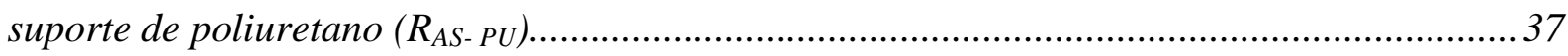

Tabela 9 - Água residuária sintética para o reator metanogênico de segunda fase $\left(R_{M I}\right)$.......39

Tabela 10 - Água residuária sintética para o reator metanogênico de fase única $\left(R_{M I I}\right) \ldots \ldots . . . .39$

Tabela 11 - Desempenho global do reator acidogênico/sulfetogênico com PEBD como material suporte $\left(R_{A S-P E B D}\right)$.

Tabela 12 - Desempenho global do reator acidogênico/sulfetogênico com espuma de PU como material suporte $\left(R_{A S-P U}\right)$

Tabela 13 - Desempenho global dos reatores metanogênico de segunda fase $\left(R_{M I}\right)$ e fase única $\left(R_{M I I}\right)$ submetidos à carga orgânica de $5 \mathrm{~g} \mathrm{~d}^{-1}$ 



\section{LISTA DE SIGLAS}

AM: arqueias metanogênicas

AP: alcalinidade parcial

AVT: ácidos voláteis totais

ASTBR: anaerobic strutured-bed reactor (reator anaeróbio de leito estruturado)

BRS: bactérias redutoras de sulfato

BF: bactérias fermentativas

CAV: carga de ácidos volumétrica

CETESB: Companhia Ambiental do Estado de São Paulo

CO: carga orgânica

$\mathbf{C O V}_{\text {afl}}$ : carga orgânica volumétrica afluente

$\mathbf{C O V}_{\text {rem: }}$ carga orgânica volumétrica removida

$\mathbf{C S V}_{\text {afl }}$ : carga de sulfato volumétrica afluente

$\mathbf{C S V}_{\text {rem: }}$ carga de sulfato volumétrica removida

DAM: drenagem ácida de mina

DQO: demanda química de oxigênio

DQO $_{\text {etanol: }}$ demanda química de oxigênio referente ao etanol

DQO $_{\text {HAc: }}$ : demanda química de oxigênio referente ao ácido acético

DQOtotal: demanda química de oxigênio total

HAc: ácido acético

LPB: Laboratório de Processos Biológicos (EESC/USP)

PEBD: Polietileno de baixa densidade 
PPG-SHS: Programa de Pós-Graduação em Engenharia Hidráulica e Saneamento (EESC/USP)

PU: poliuretano

Q: vazão afluente

Qr: vazão de recirculação

Qr/Q: taxa de recirculação

SSV: sólidos suspensos voláteis

STD: sulfeto total dissolvido

SVT: sólidos voláteis totais

$\mathbf{R}_{\text {AS-PEBD: }}$ Reator acidogênico/sulfetogênico com PEBD como material suporte

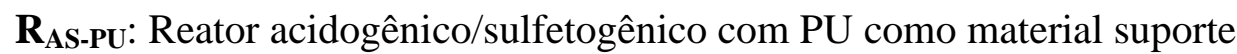

$\mathbf{R}_{\text {MI: }}$ Reator metanogênico de segunda fase

$\mathbf{R}_{\text {MII: }}$ Reator de fase única

TDH: tempo de detenção hidráulica

UASB: Upflow Anaerobic Sludge Blanket (reator anaeróbio de manta de lodo)

$\mathbf{V}_{\mathbf{a}}:$ velocidade ascensional 


\section{SUMÁRIO}

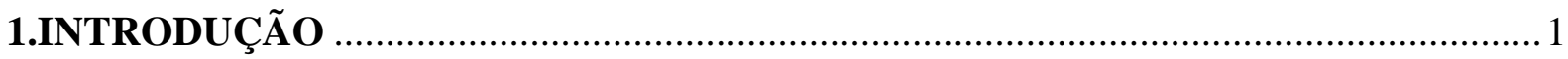

2. HIPóTESES DE TRABALHO E OBJETIVOS PROPOSTOS …...............................5

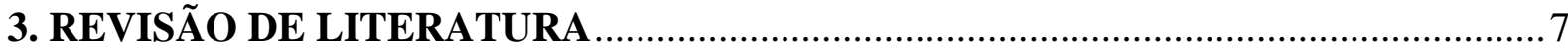

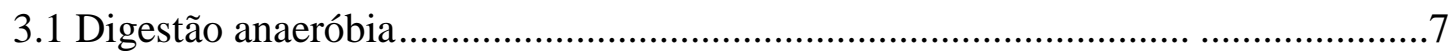

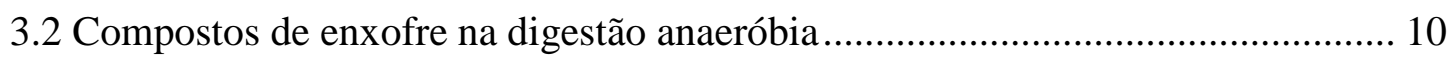

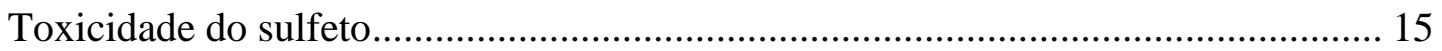

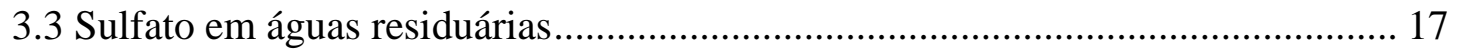

3.4 Outras tecnologias para remoção de sulfato ........................................................ 18

4. MÉTODOS, MATERIAIS E ETAPAS DA PESQUISA …........................................ 23

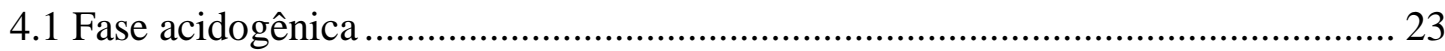

4.1.1 REATORES BIOLÓGICOS ACIDOGÊNICOS/SULFETOGÊNICOS ( $\mathrm{R}_{\mathrm{aS}-\mathrm{PEBD}} \mathrm{e}$

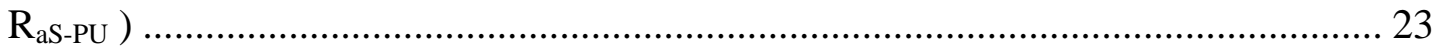

4.1.2 INÓCULO dos reatores acidogênicos/sulfetogênicos ..................................... 25

4.1.3 FASES OPERACIONAIS DO REATOR ACIDOGÊNICO/SULFETOGÊNICO com

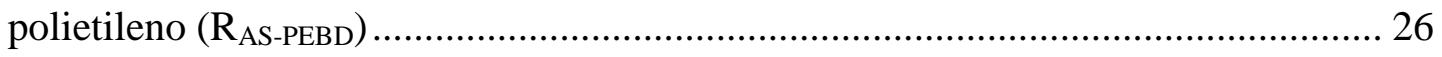

4.1.4 FASES OPERACIONAIS DO REATOR ACIDOGÊNICO/SULFETOGÊNICO com suporte de espuma de poliuretano $\left(\mathrm{R}_{\mathrm{AS}-\mathrm{PU}}\right)$.............................................................. 30

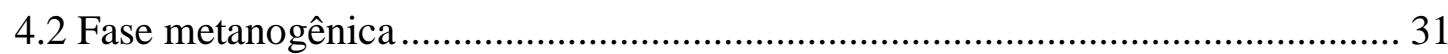

4.2.1 REATORes BIOLÓGICOs METANOGÊNICO de segunda fase e fase única 31

4.2.2 INÓCULO dos reatores metanogênico de segunda fase e fase única $\left(R_{M I}\right.$ e $\left.R_{M I I}\right)$

4.2.3 FASES OPERACIONAIS DO REATOR METANOGÊNICO DE SEGUNDA FASE

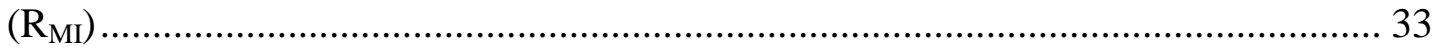

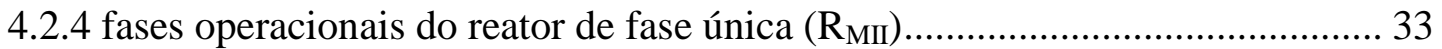

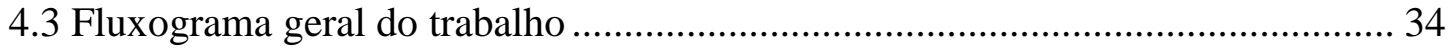

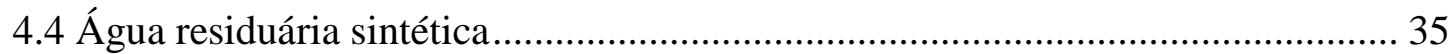

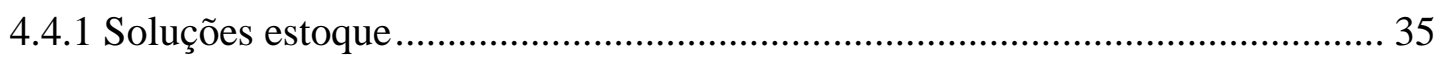

4.4.2 Água residuária sintética para os reatores acidogênicos/sulfetogênicos .......... 36

4.4.3 água residuária sintética para reatores metanogênicos de segunda fase $\left(\mathrm{R}_{\mathrm{MI}}\right)$ e FASE

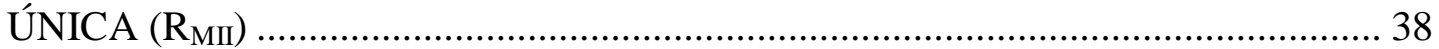

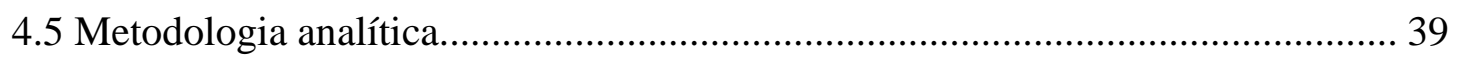

5. RESULTADOS E DISCUSSÃO

5.1 Reator acidogênicos/sulfetogênico com polietileno (PEBD) como material suporte $\left(\mathrm{R}_{\mathrm{AS}}\right.$ PEBD) 
5.1.1 ETAPA 1: ADAPTAÇÃO da biomassa para um sistema sulfetogênico 41

5.1.2 ETAPA 2: recirculação da fase líquida ........................................................... 45

5.1.3 ETAPA 3: Restabelecimento do sistema .......................................................52

5.1.4 ETAPA 4: Minimização da concentração de sulfato residual no efluente.........56

5.1.5 ETAPA 5: Redução da carga orgânica volumétrica aplicada ...........................58

5.1.6 COMPOSIÇÃO Do Biogás do reator acidogênico/sulfetogênico com PEBD como material suporte 61

5.1.7 Resumo do desempenho do reator acidogênico/sulfetoGênico com PEBD como material suporte 63

5.2 Reatores acidogênicos/sulfetogênico com espuma de poliuretano (PU) como material suporte $\left(\mathrm{R}_{\mathrm{AS}-\mathrm{PU}}\right)$

5.3 Considerações finais sobre os reatores acidogênicos/sulfetogênico primeira fase $\left(\mathrm{R}_{\mathrm{AS}}\right.$ -

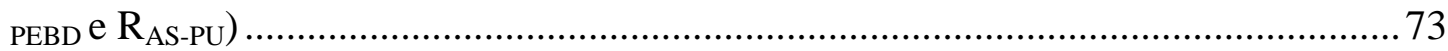

5.4 Reatores metanogênico de segunda fase e fase única ....................................... 74

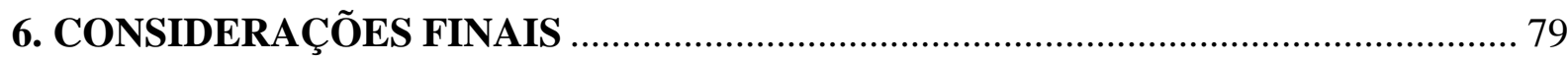

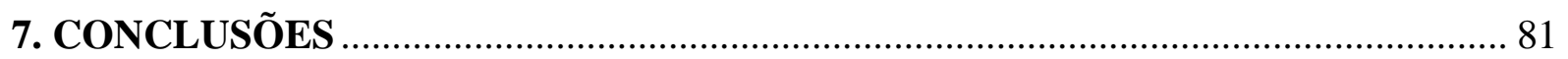

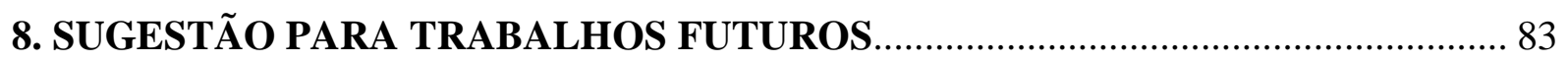

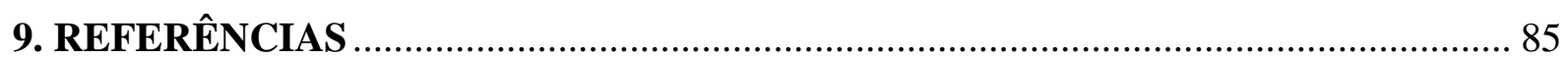




\section{INTRODUÇÃO}

A remoção de compostos orgânicos de águas residuárias é um tema amplamente consolidado. Entretanto, a remoção de compostos como nutrientes (nitrogênio, fósforo, enxofre), recalcitrantes, fármacos ainda não estão bem estabelecidos. Pesquisas explorando as rotas metabólicas e subprodutos gerados a partir da remoção desses compostos têm enriquecido o conhecimento, preenchendo as lacunas existentes.

A adequação ambiental de efluentes contendo compostos sulfurosos é um grande desafio, uma vez que essa classe de águas residuárias apresenta composição variada, o que dificulta a escolha de uma alternativa de sistema de tratamento eficiente. Os sistemas biológicos são amplamente empregados nos tratamentos de água residuárias com conteúdo orgânico, e estudos têm sido realizados para que aquelas com conteúdo sulfuroso também façam parte desse grupo. Desse modo, explorando as possibilidades dos processos de conversão envolvidos, espera-se que eles não sejam apenas um fim conveniente para atendimento da legislação, mas também uma forma de aproveitar o efluente para geração de energia a partir de biogás gerado na digestão anaeróbia e/ou para recuperação de subprodutos.

Entre as águas residuárias com características orgânicas encontram-se as com elevada concentração de sulfato, como as produzidas pelo processamento de frutos do mar, indústria de papel e celulose, vinhaça de cana-de- açúcar para produção de etanol (em faixa de temperatura termofílica). As duas últimas, nas quais o ácido sulfúrico é utilizado para branqueamento do papel e controle de microrganismos na fermentação para produção de etanol, são responsáveis pela produção de grandes volumes de efluentes líquidos. Além dos compostos sulfurosos, presente na matéria prima, como a indústria de processamento de frutos do mar ou as que o utilizam como aditivo, as águas residuárias citadas apresentam elevada concentração de matéria orgânica. A presença de sulfato, em águas residuárias submetidas ao processo anaeróbio de tratamento, pode gerar sulfeto, cujos efeitos deletérios como corrosão e odor desagradável são largamente conhecidos. A reação sulfetogênica tem o sulfato como aceptor de elétrons e a matéria orgânica como doador de elétrons, sendo chamada de redução heterotrófica. É possível a redução do sulfato de forma autotrófica, a partir do uso do hidrogênio $\left(\mathrm{H}_{2}\right)$ como doador de elétrons. A redução do sulfato é mediada pelas bactérias redutoras de sulfato (BRS), grupo de microrganismos versátil, sendo capaz de 
metabolizar vários substratos orgânicos (Muyzer \& Stams, 2008), sendo, portanto onipresentes nos inóculos utilizados.

A digestão anaeróbia de águas residuárias ricas em sulfato e matéria orgânica, permite conciliar aspectos ambientais e econômicos, tais como: [i] redução do potencial poluidor do efluente; [ii] possibilidade na geração de biogás, sendo passível sua aplicação como fonte energética; [iii] possibilidade na geração de produtos intermediários viáveis na produção de metano; [iv] redução do sulfato permitindo a recuperação do enxofre a partir da oxidação parcial do sulfeto formado.

O tratamento desse tipo de água residuária enfrenta o inconveniente associado ao sulfeto de hidrogênio $\left(\mathrm{H}_{2} \mathrm{~S}\right)$ gerado a partir da redução biológica do sulfato por bactérias redutoras de sulfato. Os efeitos podem estar relacionados à inibição da biomassa envolvida no tratamento biológico, precipitação de metais essenciais (cofatores) ao metabolismo de rotas metabólicas, corrosão de instalação por suas características ácidas, etc. O sulfeto possui três formas de especiação $\left(\mathrm{H}_{2} \mathrm{~S}, \mathrm{HS}^{-}, \mathrm{S}^{2-}\right)$, sendo forma não-dissociada $\left(\mathrm{H}_{2} \mathrm{~S}\right)$, caracterizada por seu maior poder de inibição decorrente da facilidade de permear pela parede celular, e a forma dissociada ( $\mathrm{HS}^{-}, \mathrm{S}^{2-}$ ), com menor efeito tóxico e predominante em $\mathrm{pH}$ acima do neutro (Lens, Visser, Janssen, Pol, \& Lettinga, 1998).

A produção de biogás é outro fator afetado pelo sulfeto, já que as arqueias metanogênicas (AM), responsáveis por metabolizar a matéria orgânica convertida por outros grupos de microrganismos, estão entre os organismos mais sensíveis com a presença de sulfeto (Barrera, Spanjers, Romero, Rosa, \& Dewulf, 2014). Além disso, mesmo que os organismos metanogênicos consigam atuar e produzir metano, o biogás produzido estará contaminado por sulfeto, o que encarece a utilização do metano como fonte energética, já que necessitará de uma tecnologia de purificação. Em decorrência da ausência de um sistema de tratamento para o biogás, muitas estações de tratamento promovem sua queima ao ar livre, sem aproveitamento do potencial energético.

A adoção de um sistema com separação de fases vem como alternativa para reduzir o potencial tóxico e otimizar a geração de biogás. Em sistemas termofílicos, a menor solubilidade do gás ao meio líquido reduz o aprisionamento do biogás e a perda no efluente líquido final. 
Neste contexto, o presente estudo tem por objetivo promover a remoção do sulfato sob condições acidogênicas, produzindo um efluente livre de sulfato e rico em acetato para aplicação em reator metanogênico de segunda fase. A comparação de desempenho de reatores metanogênico com separação de fase e fase única foi proposta com o objetivo de avaliar o desempenho e estabilidade dos sistemas. Os experimentos foram conduzidos em condição anaeróbia e termofílica $\left(55^{\circ} \mathrm{C}\right)$, em reator anaeróbio de leito estruturado (ASTBR), utilizando etanol como única fonte de carbono. 


\section{HIPÓTESES DE TRABALHO E OBJETIVOS PROPOSTOS}

Hipótese central:

Com base na literatura, traçou-se a hipótese da redução do sulfato ocorrer na fase acidogênica e sob condições termofílicas, sem que houvesse estabelecimento de rotas metanogênicas. Em sequência, esperava-se a geração de biogás com reduzida concentração de sulfeto em reator metanogênico de segunda fase.

Pautadas em referencial teórico, elencou-se as seguintes sub-hipóteses:

Sub-hipótese 1: a adoção de condições operacionais com reduzidas relações DQO/sulfato promovem a rota de redução de sulfato, o que favorece uma rápida partida do reator e adaptação da biomassa à condição acidogênica/sulfetogênica

Objetivo: estabelecer estratégia operacional para adaptação da biomassa em reator acidogênico/sulfetogênico, visando remoção do sulfato da fase líquida.

Sub-hipótese 2: a alteração da velocidade ascensional superficial $\left(\mathrm{V}_{\mathrm{a}}\right)$ permite maior eficiência na redução do sulfato por melhorar a transferência de massa, promovendo juntamente o stripping do sulfeto e a redução de seu potencial tóxico

Objetivo: testar diferentes velocidades ascensionais a fim de verificar os efeitos de stripping do sulfeto provocados na fase líquida e gasosa (stripping, transferência de massa).

Sub-hipótese 3: a utilização de espuma de poliuretano como material suporte permite maior adesão da biomassa sulfetogênica, o que reduz o tempo de adaptação e partida do reator, quando comparado a material suporte com menor área superficial, como os cilindros de polietileno de baixa densidade (PEBD).

Objetivo: testar cilindros de polietileno de baixa densidade (PEBD) e espuma de poliuretano (PU) como material suporte em reator acidogênico/sulfetogênico, a fim de avaliar o tempo de partida e adaptação da biomassa quanto à redução do sulfato.

Sub-hipótese 4: a separação de fases promove a remoção de compostos sulfurosos no primeiro estágio, gerando efluente líquido e gasoso de elevada qualidade em reator metanogênico de 
segunda fase, comparado ao sistema de única fase, além de permitir uma partida mais rápida em maior carga orgânica em reator de segunda fase.

Objetivos: verificar o desempenho de reatores metanogênicos comparando operação de sistemas de duas fases, aplicando efluente de reator acidogênico/sulfetogênico em reator metanogênico de segunda fase e operação de reator de fase única, alimentado com a água residuária de estudo. 


\section{REVISÃO DE LITERATURA}

\subsection{Digestão anaeróbia}

A digestão anaeróbia (FIGURA 1) é o processo biológico responsável pela degradação da matéria orgânica na ausência de oxigênio $\left(\mathrm{O}_{2}\right)$, sendo dividida em quatro principais etapas: hidrólise, acidogênese, acetogênese e metanogênese. Na presença de sulfato, uma etapa adicional pode ser incluída ao processo, a sulfetogênese.

FIGURA 1 - Esquema da digestão anaeróbia, incluindo as principais rotas (hidrólise, acidogênese, acetogênese, metanogênese e sulfetogênese). ( $\rightarrow$ metanogênese e $(-\rightarrow$ sulfetogênese

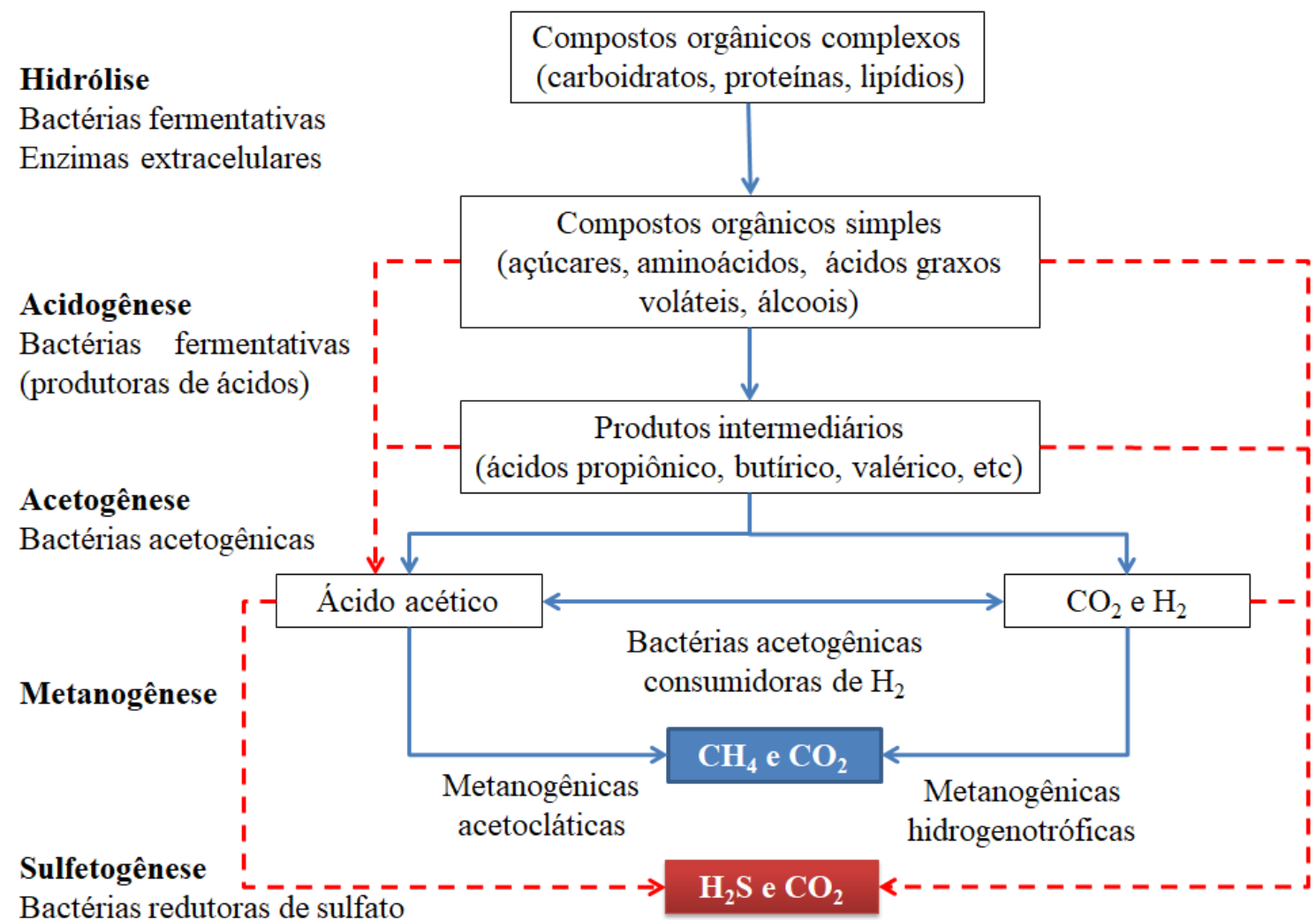

Fonte: Adaptado de Muyzer \& Stams (2008)

As bactérias responsáveis pela hidrólise convertem a matéria orgânica complexa como carboidratos, proteínas e lipídios em compostos mais simples, como açúcares, aminoácidos, álcoois. A partir desses compostos, as bactérias fermentativas (BF) ou também chamada de acidogênicas, convertem a matéria orgânica metabolizada pelas bactérias hidrolíticas em ácidos orgânicos, que por sua vez, podem ser convertidos à acetato pelas bactérias acetogênicas. As arqueias metanogênicas metabolizam acetato (metanogênicas acetoclásticas) ou hidrogênio $\left(\mathrm{H}_{2}\right)$ e dióxido de carbono $\left(\mathrm{CO}_{2}\right)$ (metanogênicas hidrogenotróficas), gerando 
metano $\left(\mathrm{CH}_{4}\right)$ e $\mathrm{CO}_{2}$. Os microrganismos metanogênicos necessitam de uma relação de sintrofismo com outras bactérias, já que não possuem a capacidade para metabolizar certos compostos.

Na presença de sulfato, outro grupo de bactérias atua no processo de digestão: as bactérias redutoras de sulfato. Diferentemente das arqueias metanogênicas (AM), às bactérias redutoras de sulfato (BRS) não necessitam da ação de um microrganismo intermediária para produzir um substrato que sejam capazes de metabolizar, sendo esse um grupo versátil, competindo com outras bactérias por substrato comum. As BRS utilizam matéria orgânica ou $\mathrm{H}_{2}$ e $\mathrm{CO}_{2}$ como doadores de elétrons na redução do sulfato (aceptor de elétrons), tendo o sulfeto de hidrogênio como principal produto.

O sistema anaeróbio tem como principais vantagens sobre o aeróbio a economia de energia por não demandar transferência de oxigênio para o tratamento, o potencial de geração de biogás, a reduzida produção de lodo (cerca de 10\% do gerado em sistemas aeróbios), reduzido requerimento nutricional (aproximadamente 20\% menor que os sistemas aeróbios) decorrente da menor geração de lodo (Doble \& Kumar, 2005; G. F. Parkin \& Speece, 1983). Como desvantagens, destaca-se o maior período de partida e estabilização, necessitando maior tempo para adaptação da biomassa, dependendo do tipo de água residuária, requerer tratamento complementar (por exemplo, remoção de fósforo e nitrogênio), a biomassa pode sofrer com as perturbações e oscilações na composição da água residuária (Metcalf \& Eddy, 2016).

A escolha de uma faixa de temperatura para o tratamento é um fator importante, sendo que entre $25-35^{\circ} \mathrm{C}$ há maior vulnerabilidade de degradação da matéria orgânica (Metcalf \& Eddy, 2016). O ideal é aliar a temperatura da água residuária com a temperatura local, sem que haja a necessidade de aquecimento ou resfriamento do afluente, o que resulta em maior gasto no tratamento. Assim, há maior aproveitamento do biogás gerado, direcionado para outras finalidades.

A fim de aliar os fatores que influenciam no tratamento biológico anaeróbio, diversas configurações de reatores são estudadas e implantadas em escala plena. O reator anaeróbio de fluxo ascendente e manta de lodo (Upflow Anaerobic Sludge Blanket - UASB) é um dos modelos mais conhecidos, devido sua biomassa autoaderida, formação de flocos e separador trifásico para evitar arraste de sólidos e separar o biogás da fração líquida. No entanto, algumas desvantagens encontradas nesse sistema fizeram com que novas configurações 
fossem estudadas, como a biomassa imobilizada em material suporte (leito estruturado, empacotado, fluidizado, etc). A vantagem da configuração utilizando material suporte é a menor vulnerabilidade a lavagem dos sólidos, robustez quanto às variações de condição e toxicidade (carga, pH, compostos tóxicos) (G. F. Parkin \& Speece, 1983) e maior área superficial para adesão do biofilme, que varia conforme o material utilizado como suporte.

A escolha da configuração para o sistema de tratamento deve levar em consideração a área requerida para implantação, difusão entre a biomassa e a água residuária (Rajeshwari, Balakrishnan, Kansal, Lata, \& Kishore, 2000), carga volumétrica aplicada, potencial aproveitamento do biogás gerado, custos de implantação e operacionais. O desempenho do reator estará relacionado à capacidade do reator em reter a biomassa, a fím de promover o crescimento e exercer um papel na biodegradabilidade (Pérez, Romero, \& Sales, 1998).

O biogás produzido durante a digestão pode ser aplicado como fonte de energia na própria planta de tratamento. Explorar seu potencial como fonte de energia é uma alternativa atrativa para a redução de custos com o tratamento. Para o caso de geração de sulfeto, há a necessidade de purificação do biogás a fim do $\mathrm{H}_{2} \mathrm{~S}$ não reduzir o poder calorífero, nem causar problemas com odor e avarias de instalações devido à corrosão (metais e concreto).

Sistemas com separação de fases, normalmente com dois reatores, um acidogênico e outro metanogênico, apresentaram resultados satisfatórios, tanto do ponto de vista da produção de $\mathrm{H}_{2}$ (reator de primeira fase) como maiores rendimentos de metano (reator de segunda fase), como demonstrado por Ferraz Jr. et al. (2016) com rendimento de $250 \mathrm{NmL}-$

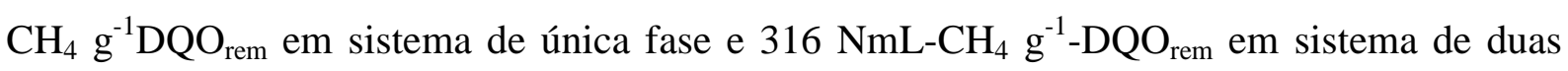
fases, operado com vinhaça sob condição termofílica. A adoção dessa estratégia operacional busca estabelecer as melhores condições para os grupos microbianos atuantes em cada uma das etapas de tratamento, como por exemplo pH, tempo de detenção hidráulica (TDH), carga orgânica volumétrica (COV), adição externa de alcalinizante, etc. Há dificuldade em manter equilíbrio entre populações distintas como as bactérias acidogênicas, acetogênicas e arqueias metanogênicas em uma mesma unidade, o que interfere no rendimento e atuação de cada uma delas, por não atingir uma condição operacional ótima comum a todas elas, principalmente quando submetidas a elevada carga orgânica (Harper \& Pohland, 1986; Yu, Fang, \& Gu, 2002). O reator anaeróbio de primeira fase pode atuar como minimizador de efeitos tóxicos sobre os organismos metanogênicos, como é o caso do sulfeto (Dinopoulou, Rudd, \& Lester, 1988). 
Outra vantagem da separação de fase é a aplicação de cargas adequadas, já que os sistemas acidogênicos costumam suportar cargas mais elevadas que os metanogênicos (Dinopoulou et al., 1988), influenciando no volume das unidades que compõem o sistema de tratamento. Além disso, ao introduzir o efluente do reator de primeira fase no reator metanogênico de segunda fase, uma pequena parte da matéria orgânica terá sido oxidada e a outra parcela convertida em ácidos durante a primeira etapa do tratamento, principalmente butírico, propiônico e acético, sendo este último o único substrato para as arqueias metanogênicas acetoclásticas. Dependendo da composição da água residuária, pode ocorrer a geração de alcalinidade, ocasionadas pela reação de redução de sulfato, a qual auxilia no tamponamento do reator de segunda fase.

$\mathrm{Na}$ literatura, estudos com de sistemas com separação de fases indicaram aumento da eficiência e rendimento da produção do biogás (Ferraz Jr. et al., 2016; Fuess, Kiyuna, et al., 2017; Luo, Xie, Zhou, \& Angelidaki, 2011), comparativamente aos sistemas de fase única. De uma maneira geral, os trabalhos com separação de fases visam à produção de $\mathrm{H}_{2}$ no primeiro estágio e posteriormente metano no reator de segunda fase.

\subsection{Compostos de enxofre na digestão anaeróbia}

O enxofre é um elemento comumente encontrado na natureza e é essencial para o metabolismo e crescimento celular. Possui estado de oxidação desde -2 (mais reduzido), o qual se encontra como sulfeto, normalmente gerado em condições anaeróbias, possuindo odor similar a ovo podre. A forma +6 (mais oxidado) está presente como sulfato, largamente aplicado em indústrias, como por exemplo, o ácido sulfúrico.

Compostos de enxofre atingem o ambiente tanto por processos naturais, como por exemplo, erupções vulcânicas, emissões oceânicas, degradação de matéria orgânica em pântanos e como antropogênicas, como a geração de poluentes provenientes da queima de combustíveis fósseis (SOx). Esses compostos causam acidificação de corpos hídricos e solo pela formação de chuva ácida. A aplicação de compostos sulfurosos em processos industriais representa aporte importante de compostos sulfurosos no ambiente.

A transformação do estado de oxidação de compostos sulfurosos pode se dar pela via físico-química ou biológica. Como exemplo, a conversão de um composto sulfuroso totalmente reduzido $\left(\mathrm{H}_{2} \mathrm{~S}\right)$ para o maior estado de oxidação pode se dar com o fornecimento de oxigênio, gerando ácido sulfúrico ao final do processo, ou em casos de aeração controlada (microaeração), converter sulfeto a enxofre elementar. 
Sob condições anaeróbias, as bactérias redutoras de sulfato (BRS) atuam reduzindo o sulfato a sulfeto, o que gera um odor desagradável (possível de ser percebido em concentração de 0,002 $\mathrm{mg} \mathrm{L}^{-1}$ no ar), corrosão de materiais, elevado potencial tóxico e passível de afetar a glândula olfativa e reduzindo a capacidade de definir odores, o que causa um grande problema na exposição, já que a percepção é alterada e algumas concentrações podem ser letais (Buisman, Geraats, Ijspeert, \& Lettinga, 1990; Metcalf \& Eddy, 2016).

Os compostos de enxofre podem sofrer redução e serem assimilados pela maioria das bactérias, por uma necessidade nutricional, sendo incorporado em compostos biológicos, tais como coenzima A, cisteína, metionina, etc (Colleran, Finnegan, \& Lens, 1995). Já a redução dissimilativa ocorre sob condição anaeróbia, em que o sulfato age como aceptor de elétrons, acoplada a oxidação de compostos orgânicos ou inorgânicos, mediado pela BRS.

O grupo de microrganismos redutores de sulfato é formado por bactérias que são capazes de utilizar uma ampla variedade de substratos orgânicos (metanol, etanol, lactato, acetato, sacarose, etc) e inorgânicos $\left(\mathrm{H}_{2}, \mathrm{CO}_{2}\right)$ como doadores de elétrons. Normalmente, os doadores de elétrons são produtos de cadeia curta, provenientes da etapa de fermentação (proteínas, polissacarídeos, lipídios) (Barton \& Hamilton, 2007). Para a matéria orgânica ser totalmente consumida pela via sulfetogênica, a relação $\mathrm{DQO} / \mathrm{SO}_{4}{ }^{2-}$ deve ser mantida no mínimo em 0,67 (Lens et al., 1998; Liamleam \& Annachhatre, 2007). A relação DQO/SO ${ }_{4}^{2-}$ direciona o fluxo de elétrons do processo, com valores menores prevalecendo a sulfetogênese e maiores a metanogênese (Colleran et al., 1995).

No processo de digestão anaeróbia, as bactérias acidogênicas hidrolíticas atuam convertendo compostos orgânicos complexos a compostos mais simples, etanol e hidrogênio, sendo passíveis de serem consumidos pelas BRS (Zhao, Ren, \& Wang, 2008). A redução do sulfato a sulfeto é mediada pelas BRS, grupo que abrange um grande consórcio microbiano com capacidade de sobreviver em diversos ambientes, além da capacidade de metabolizar mais de 100 tipos de substratos, tornando-as versáteis às diferentes condições (Muyzer \& Stams, 2008; Zhao et al., 2008). Uma das variáveis de controle mais importantes, quando se trata de reator biológico, é o $\mathrm{pH}$. Dependendo das condições de $\mathrm{pH}$ fornecida, uma determinada comunidade de bactérias pode predominar no sistema. Tal fato foi discutido nos estudos de Hwang et al. (2011), Hwang et al. (2009), Chen et al. (2008) e Mizuno, Li e Noike (1998), cujos resultados mostram a predominância de BRS em pH acima de 6,0 e valores inferiores foram inibitórios ao seu crescimento. 
As BRS podem ser divididas em dois grupos: oxidadoras incompletas (gêneros Desulfotomaculum e Desulfovíbrio) e oxidadoras completas (Desulfobacterium, Desulfosarcina, Desulfonema e Desulfobacterium) (Maillacheruvu et al., 1993). A redução do sulfato pela via incompleta tem como produto final o sulfeto e acetato, sendo esse último prontamente disponível para consumos das metanogênicas. Já as rotas metabólicas completas ocorrem a partir da oxidação de compostos orgânicos ou $\mathrm{H}_{2}$ e $\mathrm{CO}_{2}$ em sulfeto e $\mathrm{CO}_{2}$ (Lens et al., 1998). A reação de redução do sulfato utilizando determinados doadores de elétrons (Tabela 1) promove a geração de sulfeto e o íon bicarbonato. A produção de bicarbonato no processo confere alcalinidade ao meio, atuando como agente tampão no sistema. Desta forma, há redução de custos com a aplicação de reagentes a fim tamponar ou corrigir o $\mathrm{pH}$ do efluente.

Tabela 1 - Reações de redução do sulfato e produção de metano a partir de diferentes doadores de elétrons

\begin{tabular}{|c|c|c|}
\hline Processo & Reação & $\Delta \mathrm{G}^{\circ \prime} \mathrm{kJ}$ \\
\hline \multirow{11}{*}{ Sulfetogênese } & a) 2 etanol $+\mathrm{SO}_{4}^{2-} \rightarrow \mathrm{HS}^{-}+2 \mathrm{H}_{2} \mathrm{O}+\mathrm{H}^{+}+2$ Acetato $^{-}$ & $-132,7$ \\
\hline & b) 2 etanol $+3 \mathrm{SO}_{4}{ }^{2-} \rightarrow 3 \mathrm{HS}^{-}+4 \mathrm{HCO}_{3}^{-}+3 \mathrm{H}^{+}+2 \mathrm{H}_{2} \mathrm{O}$ & $-227,3$ \\
\hline & c) Acetato $^{-}+\mathrm{SO}_{4}^{2-} \rightarrow 3 \mathrm{HS}^{-}+4 \mathrm{HCO}_{-}-$ & $-47,3$ \\
\hline & d) Glicose $+\mathrm{SO}_{4}{ }^{2-} \rightarrow \mathrm{HS}^{-}+2 \mathrm{HCO}_{3}^{-}+3 \mathrm{H}^{+}+2$ Acetato $^{-}$ & $-358,2$ \\
\hline & e) $\mathrm{Glicose}+3 \mathrm{SO}_{4}{ }^{2-} \rightarrow 3 \mathrm{HS}^{-}+6 \mathrm{HCO}_{3}^{-}+3 \mathrm{H}^{+}$ & $-452,5$ \\
\hline & f) $4 \mathrm{H}_{2}+\mathrm{SO}_{4}^{2-}+\mathrm{H}^{+} \rightarrow 3 \mathrm{HS}^{-}+4 \mathrm{HCO}^{3-}$ & $-152,2$ \\
\hline & g) 4 Ác. Propiônico ${ }^{-}+3 \mathrm{SO}_{4}{ }^{2-} \rightarrow 3 \mathrm{HS}^{-}+4 \mathrm{HCO}_{3}^{-}+4$ Acetato $+\mathrm{H}^{+}$ & $-150,6$ \\
\hline & h) 4 Ác. Propiônico- $+7 \mathrm{SO}_{4}{ }^{2-} \rightarrow 7 \mathrm{HS}^{-}+12 \mathrm{HCO}_{3}{ }^{-}+\mathrm{H}^{+}$ & -341 \\
\hline & i) 4 Ác. Butírico-+ $10 \mathrm{SO}_{4}{ }^{2-} \rightarrow 10 \mathrm{HS}^{-}+16 \mathrm{HCO}_{3^{-}}+2 \mathrm{H}^{+}$ & -492 \\
\hline & j) 2 Ác. Butírico-+ $\mathrm{SO}_{4}{ }^{2-} \rightarrow \mathrm{HS}^{-}+4$ Acetato $^{-}+2 \mathrm{H}^{+}$ & $-55,5$ \\
\hline & k)2 Ac. Lático $+\mathrm{SO}_{4}{ }^{2-} \rightarrow \mathrm{HS}^{-}+2 \mathrm{HCO}_{3^{-}}+2 \mathrm{H}^{+}+4$ Acetato & $-160,1$ \\
\hline \multirow{2}{*}{ Metanogênese } & 1) Acetato ${ }^{-}+\mathrm{H}_{2} \mathrm{O} \rightarrow \mathrm{CH}_{4}+\mathrm{HCO}_{3}^{-}$ & -31 \\
\hline & m) $4 \mathrm{H}_{2}+\mathrm{H}^{+}+\mathrm{HCO}^{3-} \rightarrow \mathrm{CH}_{4}+3 \mathrm{H}_{2} \mathrm{O}$ & $-135,6$ \\
\hline
\end{tabular}

Fonte: Adaptado de Saady(2013) e Zhou and Xing (2015)

Em ambientes marinhos, as BRS são responsáveis por aproximadamente $50 \%$ da mineralização da matéria orgânica nos sedimentos (Muyzer \& Stams, 2008; Plugge, Zhang, Scholten, \& Stams, 2011). Por isso, sedimento marinho é uma rica fonte de inóculo para sistemas sulfetogênico Em limitada concentração de sulfato, as BRS podem atuar como 
bactérias fermentativas, podendo converter etanol a $\mathrm{H}_{2}$ (Martins \& Pereira, 2013; Plugge et al., 2011; Thauer, Jungermann, \& Decker, 1977). Martins \& Pereira (2013) utilizaram a bactéria Desulfovibrio vulgaris para avaliar o potencial de produção de $\mathrm{H}_{2}$ a partir de BRS. Observou-se o aumento da produção de $\mathrm{H}_{2}$ quando o $\mathrm{pH}$ foi alterado de 6,6 para 7,0, cuja a faixa ótima de atuação das BRS encontra-se próximo de pH neutro (Martins \& Pereira, 2013). Entretanto, Hao et al., (2014) reportaram que as BRS, responsáveis pela redução do sulfato a sulfeto, são organismos que crescem em uma ampla faixa de temperatura $\left(0\right.$ a $\left.100^{\circ} \mathrm{C}\right), \mathrm{pH}(3-$ 9,8) e condições com elevada salinidade. São capazes de utilizar diversos doadores de elétrons, tais como açucares, ácidos, compostos aromáticos, acetato, butirato, propionato e lactato (via heterotrófica) sendo os dois últimos os mais favoráveis que os demais substratos (Hao et al., 2014; Liamleam \& Annachhatre, 2007; Muyzer \& Stams, 2008). Já pela via autotrófica, $\mathrm{H}_{2}$ e $\mathrm{CO}_{2}$ resultam em $\mathrm{CO}_{2}$ e $\mathrm{H}_{2} \mathrm{~S}$.

Algumas espécies de grupos das Desulfovibrio e outras BRS podem agir na fermentação de compostos, tais como etanol, lactato, glicerol, propionato, acetato ocorrendo apenas se a pressão parcial de $\mathrm{H}_{2}$ se mantiver baixa, consumido pelas metanogênicas hidrogenotróficas (Hansen, 1993; Widdel, 1988 citado por Colleran, Finnegan, \& Lens, 1995; Gibson, 1990). Nesse caso, o sintrofismo ocorre entre as fermentativas que geram $\mathrm{H}_{2}$, as metanogênicas hidrogenotróficas consumidoras do $\mathrm{H}_{2}$ e responsáveis em deslocar o equilíbrio da reação por reduzir sua pressão parcial e as metanogênicas acetoclásticas, consumidoras do acetato formado juntamente com o $\mathrm{H}_{2}$ pelas fermentativas.

Etanol $+\mathrm{H}_{2} \mathrm{O} \rightarrow$ Acetato $^{-}+\mathrm{H}^{+}+2 \mathrm{H}_{2}$

(Reação 1)

Lactato $+2 \mathrm{H}_{2} \mathrm{O} \rightarrow$ Acetato $^{-}+\mathrm{HCO}_{3}^{-}+\mathrm{H}^{+}+2 \mathrm{H}_{2}$

(Reação 2)

As BRS são os únicos microrganismos com capacidade de utilizar o sulfato inorgânico como aceptor final de elétrons (Barton, 1995). Esses organismos competem por substrato com outros microrganismos, como as fermentativas, as homoacetogênicas e metanogênicas (Muyzer \& Stams, 2008). No entanto, as metanogênicas metabolizam um número limitado de substratos e não são capazes de oxidar diretamente compostos complexos. Nesse caso, a relação de sintrofismo é essencial para o sucesso entre sulfetogênese e metanogênese, já que os subprodutos da oxidação incompleta são convertidos a acetato, principal substrato para as metanogênicas. 
Assim como outros organismos, as BRS necessitam de alguns metais para auxiliar no transporte de elétrons e também como cofatores nas enzimas, como ferro, cobre, zinco, cobalto, molibdênio, níquel. Elevadas concentrações de metais ocasionam inibição da atividade microbiana, sendo que as concentrações desejadas em ordem decrescente de toxicidade são: $\mathrm{Cu}<4 \mathrm{mg} \mathrm{L}^{-1}, \mathrm{Cd}<11 \mathrm{mg} \mathrm{L}^{-1}, \mathrm{Ni}<13 \mathrm{mg} \mathrm{L}^{-1}, \mathrm{Zn}<16,5 \mathrm{mg} \mathrm{L}^{-1}, \mathrm{Cr}<35 \mathrm{mg}$ $\mathrm{L}^{-1}, \mathrm{~Pb}<80 \mathrm{mg} \mathrm{L}^{-1}$ (Hao et al., 2014), porém as BRS podem ser afetadas pela ausência de metais essenciais (Koschorreck, 2008), devido à formação de precipitado insolúvel a partir da associação de metal e sulfeto (sulfeto metálico).

A precipitação do sulfeto é uma alternativa aplicada ainda no tratamento anaeróbio associado à presença de metais, formando sulfeto metálico, muito aplicado com drenagem ácida de mina (DAM), cuja água residuária contém elevada concentração de ambos os compostos. Esse processo reduz a toxicidade ao sulfeto e a elevada concentração de metais na digestão anaeróbia. Porém, a DAM é pobre em matéria orgânica, demandando de adição externa ou misturando efluente com compostos orgânicos e atenda a razão $\mathrm{DQO} / \mathrm{SO}_{4}{ }^{2-}$ mínima de 0,67 para atuação da sulfetogênese. Após a formação do precipitado de sulfeto metálico, o metal pode passar pelo processo de recuperação, necessitando separá-lo da fração líquida por processo de sedimentação ou filtração (Barton \& Hamilton, 2007; Godoi, Foresti, \& Damianovic, 2017).

A relação sintrófica existente entre microrganismos redutores de sulfato e metanogênicos faz com que não ocorra acúmulo de subproduto, como é o caso do ácido acético produzido em algumas reações de redução do sulfato (Tabela 1). Mesmo havendo alguns substratos comuns aos dois grupos, o sintrofismo pode funcionar como um regulador biológico do sistema, de forma a reduzir o acúmulo e efeitos tóxicos.

A presença dos metabolismos sulfetogênicos e metanogênico em um mesmo sistema são responsáveis pela mineralização da matéria orgânica presente (Colleran et al., 1995). A competição e a maior tendência termodinâmica para rotas metabólicas específicas a determinados substratos (Tabela 1) faz com que as BRS oxidem compostos orgânicos ou inorgânicos, desviando parte dos doadores de elétrons para a redução dissimilativa do sulfeto, ocasionando menor formação de metano. Além disso, o sulfeto afeta rapidamente as arqueias metanogênicas, já que estas são organismos sensíveis a exposição do sulfeto, acarretando em perda de desempenho para a rota de geração do metano. As concentrações de inibição causada por sulfeto encontradas na literatura variam conforme $\mathrm{pH}$, especiação do sulfeto, tipo de 
substrato, tipo de reator ( biomassa suspensa, aderida, autoaderida) etc, o que torna a concentração tóxica difícil de ser determinada, por depender de diversos fatores.

\section{TOXICIDADE DO SULFETO}

A toxicidade do sulfeto se dá pela sua facilidade em permear a célula através da membrana celular dos microrganismos, causando a desnaturação de proteínas pela formação de sulfeto e dissulfeto entre as cadeias de peptídeos, interferindo no metabolismo enzimático e pH intracelular (Chen et al., 2008; Lens et al., 1998; McCartney and Oleszkiewicz, 1993).

Normalmente, as bactérias fermentativas sofrem menor interferência causada pelo sulfeto do que as próprias redutoras de sulfato, acetogênicas e as arqueias metanogênicas (McCartney \& Oleszkiewicz, 1993), sendo esse último o grupo mais afetado.

Os efeitos do sulfeto na digestão anaeróbia não estão associados somente à concentração de sulfeto total dissolvido (STD) e sim em sua especiação. A temperatura e o pH são dois fatores que estão diretamente ligados à especiação do sulfeto, podendo ser dividido em três formas: $\mathrm{H}_{2} \mathrm{~S}$ (não dissociada), $\mathrm{HS}^{-}$e $\mathrm{S}^{2-}$ (dissociadas) (Reação 3) (Hilton \& Oleszkiewicz, 1988).

$\mathrm{H}_{2} \mathrm{~S} \rightleftharpoons \mathrm{H}^{+}+\mathrm{HS}^{-} \rightleftharpoons 2 \mathrm{H}^{+}+\mathrm{S}^{2-}$

(Reação 3)

Em temperatura de $30^{\circ} \mathrm{C}$, o valor de pKa é de 6,9 (Lens et al., 1998), isto é, nessa condição $50 \%$ do sulfeto está na forma $\mathrm{H}_{2} \mathrm{~S}$ e o restante como HS .

A concentração adequada de sulfeto para as arqueias metanogênicas varia de 8 a 22 $\mathrm{mg} \mathrm{L} \mathrm{L}^{-1}$ de sulfeto total, apresentando inibição em concentrações em torno de $50 \mathrm{mg} \mathrm{\textrm {L } ^ { - 1 }}$ (Hilton \& Oleszkiewicz, 1988). A competição entre BRS e AM pode ocorrer e provocar redução no rendimento de metano, além de estresse sobre as produtoras de metano devido a elevadas concentrações de sulfeto (Maillacheruvu et al., 1993; Overmeire, Lens, \& Verstraete, 1994).

No entanto, as arqueias metanogênicas também são capazes de se adaptar a elevados níveis de sulfeto em reatores anaeróbios com biomassa aderida (Chen et al., 2008). A inibição ou a tolerância as concentrações de sulfeto dependem de fatores como pH do meio, concentração e especiação do sulfeto, tipo de substrato, consórcio microbiano, associação com outros compostos inibidores, além da forma de apresentação dos microrganismos, dispersos ou imobilizados. 
FIGURA 2 - Especiação do sulfeto em diferentes valores de $\mathrm{pH}$ à $30^{\circ} \mathrm{C}$ : Caixa de $\mathrm{pH}$ da digestão anaeróbia, $\mathrm{pH}$ ótimo para metanogênese

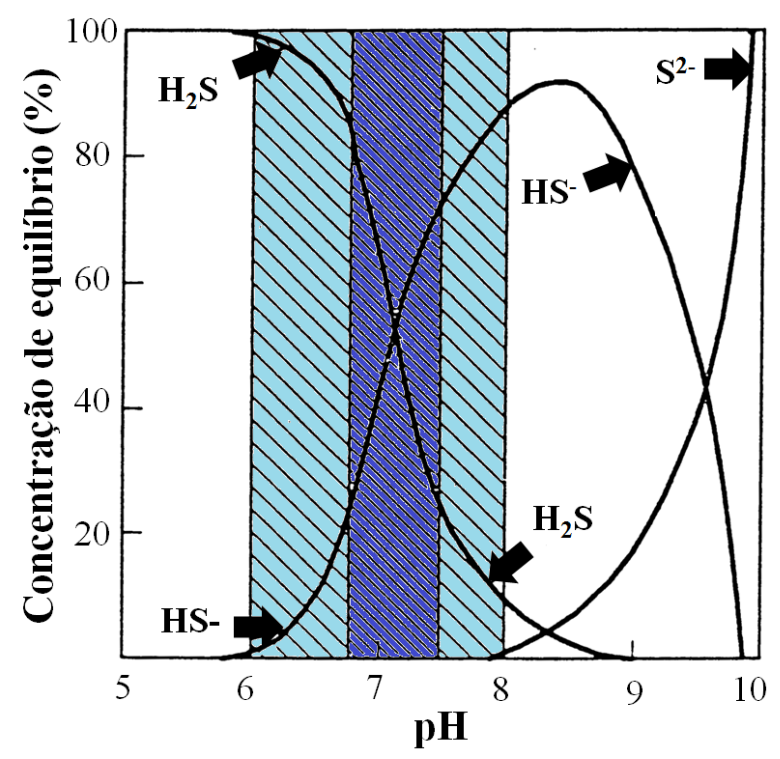

Fonte: Adaptado de Lens et al. (1998)

Na literatura, os níveis de toxicidade reportados por Parkin et al. (1990) variaram entre 100-800 $\mathrm{mg} \mathrm{L}^{-1}$ para sulfeto total dissolvido $\left(\mathrm{HS}^{-}\right.$e $\mathrm{H}_{2} \mathrm{~S}$ ) em organismos produtores de metano e 50-200 mg $\mathrm{H}_{2} \mathrm{~S} \mathrm{~L}^{-1}$ (forma não dissociada), causando inibição não só das AM como em outros microrganismos anaeróbios, sendo menos susceptíveis aos efeitos negativos em reator com biomassa imobilizada (Doble \& Kumar, 2005). Barrera et al. (2014) observaram que a redução da relação DQO/ $\mathrm{SO}_{4}{ }^{2-}$ (aproximadamente 5) resultou $300 \mathrm{mg} \mathrm{L}^{-1}$ da forma $\mathrm{H}_{2} \mathrm{~S}$, reduzindo o desempenho dos metabolismos metanogênico e sulfetogênico. Em estudos realizados por Van Houten et al. (1994), verificou-se a aplicação de $\mathrm{H}_{2}$ e $\mathrm{CO}_{2}$ em reatores visando à redução do sulfato utilizando pedra pome para adesão da biomassa, se adaptando a concentração de $\mathrm{H}_{2} \mathrm{~S}$ de até $450 \mathrm{mg} \mathrm{L}^{-1}$, sendo observada inibição reversível a essa condição com elevada concentração de sulfeto livre. Lens et al. (1998) descreveram que o sulfeto causa menor inibição em reator com lodo granular que os reatores de biomassa suspensa.

Hilton \& Oleszkiewicz (1988) reportaram que o mecanismo de inibição por sulfeto ocorre de forma diferenciada entre os grupos de microrganismo, onde a forma não-ionizada afeta mais a utilização do acetato do que a concentração de sulfeto total.

O sulfeto pode interferir na disponibilidade de metais essenciais ao metabolismo anaeróbio. O sulfeto quando associado a um metal, forma um precipitado de sulfeto metálico, reduzindo a biodisponibilidade. 
Em estudo realizado por Dahar, Elbeshbishy, \& Nakhla (2012), verificou-se que a dosagem de ferro em aproximadamente 3 a 4 vezes a estabelecida em relação estequiométrica $\left(875 \mathrm{mg} / \mathrm{L} \mathrm{Fe}^{2+}\right.$ para $500 \mathrm{mg} / \mathrm{L} \mathrm{S}^{2-)}$ para a precipitação total de ferro e sulfeto na forma de $\mathrm{FeS}$, favoreceu as bactérias produtoras de hidrogênio. Concentração de sulfeto em torno de 25 $m g \mathrm{~L}^{-1}$ mostrou-se positiva para a fermentação, como uma fonte de enxofre para suprir as necessidades nutricionais da célula.

\subsection{Sulfato em águas residuárias}

A ocorrência de sulfato em águas residuárias industriais se deve, em grande medida, ao uso de compostos sulfurosos como o ácido sulfúrico para controle de $\mathrm{pH}$ e contaminação por microrganismos, além de sulfetos, bissulfetos e outros nos processos de branqueamento.

$\mathrm{Na}$ fermentação para produção de álcool a partir da cana-de-açúcar, a eventual presença de microrganismos contaminantes, tais como as bactérias lácticas, que utilizam nutrientes e açúcares levam à inibição do crescimento das leveduras. Como consequência, observa-se a redução no rendimento da produção do etanol (Kram, 2008; Muthaiyan, Limayem, \& Ricke, 2011; Oliva-Neto, Dorta, Carvalho, Lima, \& Silva, 2013). A dosagem de ácido sulfúrico aplicada para controle de microrganismos varia ao longo da safra, sendo que em caracterização realizada por Santos, Rosa, Sakamoto, Varesche e Silva (2014) foram determinados valores de concentração que variaram de 1400 a $2600 \mathrm{mg} / \mathrm{L}$ de sulfato. O resultado dos processos de branqueamento do açúcar e controle da fermentação são as altas concentrações de íons sulfato no efluente de usinas de produção de álcool e açúcar (Tang et al., 2010). Em destilarias indianas cujas principais matérias-primas são o melaço e o malte de cevada (Lata, Kansal, Balakrishnan, Rajeshwari, \& Kishore, 2002), a concentração de sulfato no efluente pode variar de 1100-18000 $\mathrm{mg} \mathrm{L}^{-1}$, DQO entre 100.000-150.000 $\mathrm{mg} \mathrm{L}^{-1}$ e DBO 35.000-50.000 mg L $\mathrm{mg}^{-1}$ (Doble \& Kumar, 2005), superiores às encontradas na produção de álcool em outros países

A vinhaça de cana-de-açúcar, produzida em usina de álcool e açúcar apresenta DQO em torno de $33.000 \mathrm{mg} / \mathrm{L}$, (Santos et al., 2014) sendo que neste caso a relação DQO/Sulfato é de aproximadamente 13, variável dependendo do tipo de vinhaça e período da safra.

Com geração de aproximadamente 12 L de vinhaça por litro de etanol (Leme \& Seabra, 2017), a destinação dada para a vinhaça no Brasil normalmente tem como destinação a fertirrigação das lavouras, aproveitando o elevado teor de nutrientes e matéria orgânica, reduzindo a adição de adubação mineral. Apesar dos benefícios nutricionais que essa prática 
pode trazer, há vários aspectos negativos, tais como o acúmulo de metais, acidificação do solo devido à degradação de compostos orgânicos, geração de mal odor (acidificação da matéria orgânica e redução do sulfato a sulfeto) e riscos de contaminação do lençol freático. A taxa de aplicação da vinhaça no solo leva em conta a concentração de potássio para dosar o volume (Elia Neto, 2016), o que pode extrapolar a concentração de outros compostos potencialmente nocivos. No Estado de São Paulo, os critérios de aplicação da vinhaça no solo são dispostos pela norma técnica 4.231 da Companhia Ambiental do Estado de São Paulo (CETESB, 2015).

Águas residuárias de indústrias de papel e celulose possuem altos teores de matéria orgânica e compostos de enxofre. Em seu processamento, há utilização de sulfureto de sódio $\left(\mathrm{Na}_{2} \mathrm{~S}\right)$ no processo de Kraft, mistura de ácido sulfuroso $\left(\mathrm{H}_{2} \mathrm{SO}_{3}\right)$ e íons de bissulfeto (- $\left.\mathrm{HSO}_{3}\right)$ para dissolver a lignina. O processo demanda grande quantidade de água, o que gera uma quantidade grande de efluente (Pokhrel \& Viraraghavan, 2004).

$\mathrm{Na}$ indústria têxtil, os níveis de sulfato no efluente atingem elevados níveis de concentração (20 a $42 \mathrm{~g} \mathrm{~L}^{-1}$ ), aplicado como aditivo no processo de tingimento (Delée, O’Neill, Hawkes, \& Pinheiro, 1998; Yurtsever, Çinar, \& Sahinkaya, 2016; Zeng, Hao, Mackey, Wei, \& Guo, 2017). As principais fontes orgânicas provem de amidos, enzimas, gorduras, graxas, ceras, ácido acético, solventes, resinas e surfactantes, sendo alguns recalcitrantes. (Delée et al., 1998). O efluente com elevada temperatura (aproximadamente $50^{\circ} \mathrm{C}$ ) favorece o tratamento biológico anaeróbio sob condições termofílica (Delée et al., 1998; Doble \& Kumar, 2005), sendo que a taxa de conversão em reatores termofílicos é mais elevada quando comparada à observada em condições mesofílicas (Liamleam \& Annachhatre, 2007).

Alguns países como China e Hong Kong fazem a prática da água de reúso em descarga de sanitários. Para esses casos, a concentração de sulfato em esgoto salino é em média de 550 mg (Hao et al., 2014).

A presença de sulfato tanto em esgoto sanitário como efluentes industriais ainda requer estudo para compreensão do processo e investigação de alternativas para redução dos efeitos deletérios já conhecidos.

\subsection{Outras tecnologias para remoção de sulfato}

Devido à elevada quantidade de efluentes com sulfato em sua composição, buscam-se alternativas de remoção associadas para sistema de tratamento. Entre os principais processos, 
estão: redução do sulfato por via anaeróbia, desnitrificação autotrófica com oxidação do sulfeto, precipitação de sulfeto com metais, geração de enxofre elementar por processo de micro aeração, stripping do sulfeto para posterior tratamento do biogás.

O sulfeto gerado na digestão anaeróbia pode ser utilizado como doador de elétrons em processo de remoção de nutrientes, como a desnitrificação autotrófica. Associação da remoção de compostos de nitrogênio (nitrato/nitrito) e o sulfeto, em que o composto de enxofre é utilizado como doador de elétrons, além de ser um processo biotecnológico eficiente, reduz custos de tratamento. A oxidação completa a partir de nitrato e nitrito estão representadas respectivamente pelas Reações 4 e 5 (Moraes, Souza, \& Foresti, 2012):

Nitrato:

$5 \mathrm{HS}^{-}+8 \mathrm{NO}_{3}{ }^{-}+3 \mathrm{H}^{+} \rightarrow 5 \mathrm{SO}_{4}{ }^{2-}+4 \mathrm{~N}_{2}+4 \mathrm{H}_{2} \mathrm{O}$

$\Delta G_{m}^{\theta}=-3.848 \mathrm{~kJ} \mathrm{~mol}^{-1}$

Nitrito:

$3 \mathrm{HS}^{-}+8 \mathrm{NO}_{2}^{-}+5 \mathrm{H}^{+} \rightarrow 3 \mathrm{SO}_{4}^{2-}+4 \mathrm{~N}_{2}+4 \mathrm{H}_{2} \mathrm{O}$

(Reação 5)

$\Delta G_{m}^{\theta}=-2.944 \mathrm{~kJ} \mathrm{~mol}^{-1}$

O processo de oxidação do sulfeto também pode ocorrer, formando como produtos, o enxofre elementar como composto com estado de oxidação parcial (Reação 6 e 7) (Jing, Ping, \& Mahmood, 2010).

Nitrato:

$\mathrm{HS}^{-}+2 / 3 \mathrm{NO}_{3}^{-}+7 / 5 \mathrm{H}^{+} \rightarrow \mathrm{S}^{0}+1 / 2 \mathrm{~N}_{2}+6 / 5 \mathrm{H}_{2} \mathrm{O}$

$\Delta G_{m}^{\theta}=-252,8 \mathrm{~kJ} \mathrm{~mol}^{-1}$

Nitrito:

$\mathrm{HS}^{-}+2 / 3 \mathrm{NO}_{2}^{-}+5 / 3 \mathrm{H}^{+} \rightarrow \mathrm{S}^{0}+1 / 3 \mathrm{~N}_{2}+4 / 3 \mathrm{H}_{2} \mathrm{O}$

(Reação 7)

$\Delta G_{m}^{\theta}=-305,7 \mathrm{~kJ} \mathrm{~mol}^{-1}$

A oxidação parcial do sulfeto é termodinamicamente menos favorável que a oxidação completa a sulfato, limitada pela concentração de nitrito e nitrato. No entanto, controle de dosagem seguindo a estequiometria de oxidação pela via parcial, representa uma alternativa, 
já que o enxofre elementar pode ser recuperado e comercializado. Há a possibilidade de aplicar como fonte de sulfeto, o efluente de reator anaeróbio com sulfeto dissolvido na fase líquida ( $\left.\mathrm{HS}^{-}, \mathrm{H}_{2} \mathrm{~S}, \mathrm{~S}^{2-}\right)$, ou então, a inserção de sulfeto na fase gasosa $\left(\mathrm{H}_{2} \mathrm{~S}\right)$. O sulfeto gasoso pode ser proveniente do biogás gerado em processo anaeróbio, tratando água residuária rica em sulfato.

A geração de enxofre elementar pode ocorrer por processo biológico ou químico de oxidação parcial em condições de limitação de oxigênio (0,2-1,0 $\mathrm{mg} \mathrm{L}^{-1}$ ) (Lohwacharin \& Annachhatre, 2010), onde há formação de um produto intermediário insolúvel e separando da fração líquida (Reação 8) e geração de sulfato quando o oxigênio está em excesso (Reação 9) (Janssen et al., 1995). Camiloti et al., (2016) utilizaram membrana de silicone como material para promover a micro aeração do sistema, atingindo valores médios de remoção do sulfeto acima de $94 \%$.

$$
\begin{array}{ll}
2 \mathrm{HS}^{-}+\mathrm{O}_{2} \rightarrow 2 \mathrm{~S}^{0}+2 \mathrm{OH}^{-} & \Delta \mathrm{G}^{0}=-169,35 \mathrm{~kJ} \mathrm{~mol}^{-1} \\
2 \mathrm{HS}^{-}+4 \mathrm{O}_{2} \rightarrow 2 \mathrm{SO}_{4}{ }^{2-}+2 \mathrm{H}^{+} & \Delta \mathrm{G}^{0}=-732,58 \mathrm{~kJ} \mathrm{~mol}^{-1}
\end{array}
$$

A remoção do composto de enxofre presentes em água residuária (solução aquosa) também pode se dar por transferência da fase líquida para a gasosa e posteriormente sólida, aplicando processo físico-químico de adsorção de sulfeto contido no biogás em carvão ativado ou outros adsorventes alternativos (lodo de estação de esgoto, fibra de coco, etc) (Ansari, Bagreev, \& Bandosz, 2005; Garcia, 2014; Rio, Faur-Brasquet, Le Coq, \& Le Cloirec, 2005). Essa estratégia é interessante, mas deve ser devidamente avaliada para que o processo não seja inviabilizado por elevados custos no tratamento de remoção do composto de interesse da fase sólida ou disposição do material adsorvido, associado a perda de produto com valor econômico. Quando são adotados sistemas de tratamento anaeróbio operados em pH próximo do neutro, o sulfeto encontra-se em grande parcela concentrado no biogás. Para aproveitamento do metano produzido purificação é necessária antes de sua aplicação como fonte de energia.

Nos sistemas convencionais de única fase, uma parcela do sulfeto produzido é transferida para o biogás e outra parcela mantida no efluente líquido final. A busca por alternativas a fim de reduzir os efeitos negativos da presença do sulfeto em biogás para utilização de seu potencial energético e implicações sobre a comunidade microbiana metanogênica na presença de sulfeto têm merecido interesse de pesquisadores. A separação de 
fases tem sido avaliada para aumentar a eficiências nos processos biológicos e reduzir efeitos inibitórios devido a subprodutos gerados ao longo do processo.

Nesta forma, o presente trabalho visou avaliar diversas condições operacionais a fim de estabelecer um sistema com separação de fases acidogênico/sulfetogênico e metanogênico, com o objetivo de reduzir os potenciais tóxicos do sulfeto principalmente sobre a comunidade metanogênica e para a geração de biogás contendo metano com baixa concentração de sulfeto. 


\section{MÉTODOS, MATERIAIS E ETAPAS DA PESQUISA}

A presente pesquisa visou investigar o desempenho de reatores operados com separação parcial de fases acidogênica/sulfetogênica e metanogênica e comparar com o sistema único (acidogênico/sulfetogênico/metanogênico).

Como primeira etapa, verificaram-se estratégias para estabilização de um sistema de primeira fase (destinada para remoção de sulfeto) com operação de reatores acidogênicos/sulfetogênicos com cilindros de polietileno de baixa densidade $\left(\mathrm{R}_{\mathrm{AS}-\mathrm{PEBD}}\right)$ e espuma de poliuretano $\left(\mathrm{R}_{\mathrm{AS}-\mathrm{PU}}\right)$ com o materiais suporte.

A segunda etapa teve o objetivo de avaliar a partida e desempenho de dois reatores para digestão anaeróbia completa, sendo um de fase única e o outro de segunda fase (alimentado com efluente de reator de primeira fase), submetidos às mesmas condições de carga orgânica $(\mathrm{CO})$, porém o primeiro tendo a água residuária bruta como afluente e o segundo recebendo água residuária sintética similar ao efluente do reator acidogênico/sulfetogênico. Destaca-se que não foi possível armazenar os efluentes do sistema de primeira fase para alimentação do reator de segunda fase, uma vez que o sulfeto presente era perdido na etapa, por volatilização ou reoxidação.

\subsection{Fase acidogênica}

\subsubsection{REATORES BIOLÓGICOS ACIDOGÊNICOS/SULFETOGÊNICOS $\left(\mathrm{R}_{\mathrm{AS}-\mathrm{PEBD}}\right.$ e $\mathrm{R}_{\mathrm{AS}-}$ $\mathrm{PU})$}

$\mathrm{Na}$ etapa acidogênica, empregou-se um reator anaeróbio de leito estruturado (FIGURA 3), construído em tubo de acrílico, com dimensões de 61,5 mm de diâmetro interno, $820 \mathrm{~mm}$ de altura total, sendo $15 \mathrm{~cm}$ da câmara de alimentação, $50,5 \mathrm{~cm}$ de leito estruturado e 16,5 da câmara de saída, totalizando um volume útil de 2,08 L para reator acidogênico/sulfetogênico I $\left(\mathrm{R}_{\mathrm{AS}-\mathrm{PEBD}}\right)$ e 2,04 L para reator acidogênico/sulfetogênico II ( $\left.\mathrm{R}_{\mathrm{AS}-\mathrm{PU}}\right)$. 
FIGURA 3 - Representação esquemática do aparato experimental utilizado na fase acidogênica/sulfetogênica: 1- reservatório de efluente sintético, 2 - bomba peristáltica para alimentação, 3 - câmara de entrada do afluente, 4 - região reacional (leito estruturado - (a) material suporte em PEBD; (b) material suporte em PU, 5- amostradores (A-E), 6 - linha de recirculação, 7 - bomba dosadora para recirculação, 8 - câmara de saída do efluente, 9 - septo para amostragem da fase líquida, 10 - saída do efluente, 11 - saída do biogás, 12 - selo hídrico, 13 - medidor de gás.

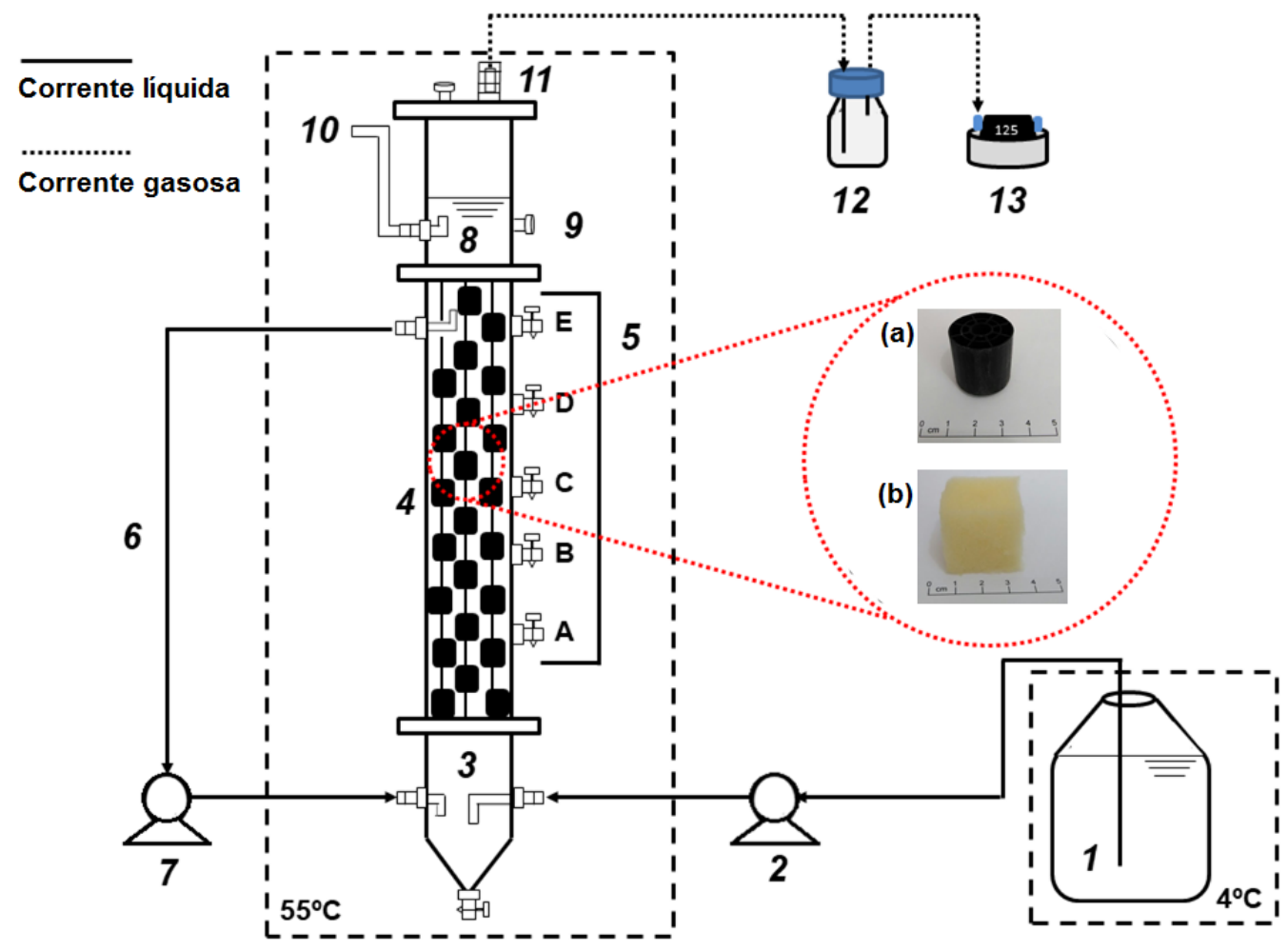

Fonte: Elaboração própria

Como meio suporte, optou-se por utilizar cilindros de polietileno de baixa densidade (PEBD) para reator $\mathrm{R}_{\mathrm{AS}-\mathrm{PEBD}}$ (FIGURA 3-a), já que vários trabalhos aplicaram esse material em operação de reatores acidogênicos (Anzolas-Rojas, 2014; Carminato, 2013). O cilindro possui uma área superficial específica de $7,9 \mathrm{~m}^{2} \mathrm{~g}^{-1}$, densidade aparente de $0,96 \mathrm{~g} \mathrm{~mL}^{-1} \mathrm{e}$ diâmetro equivalente de 2,5 cm (Anzola-Rojas, Zaiat, \& De Wever, 2016).A vantagem de sua aplicação é a facilidade em arranjar os cilindros de forma intercalada, reduzindo zonas mortas no reator. Outro ponto positivo é a manutenção de biomassa, evitando colmatação do leito por excesso.

Já no reator $\mathrm{R}_{\mathrm{AS}-\mathrm{PU}}$, aplicaram-se cubos de espuma de poliuretano (PU) (FIGURA 3-b) como material suporte, com dimensões de aproximadamente $2,5 \times 2,5 \times 2,5 \mathrm{~cm}$, já que alguns trabalhos cuja vertente focava no estabelecimento da sulfetogênese utilizaram esse material 
(Camiloti et al., 2014; Godoi, Damianovic, \& Foresti, 2015; Rodriguez, Oliveira, Raimundi, \& Zaiat, 2012; Silva, Hirasawa, Varesche, Foresti, \& Zaiat, 2006).

Os cilindros de PEBD (FIGURA 4-a) e os cubos de PU (FIGURA 4-b) foram posicionados em seis hastes de PVC, colocados em camadas intercalas de três em três peças.

FIGURA 4 - Vista superior do material suporte no reator: (a) Cilindros de polietileno de baixa densidade (PEBD)- $\mathrm{R}_{\mathrm{ASI}}$; (b) Cubos de espuma de poliuretano (PU)- $\mathrm{R}_{\mathrm{ASII}}$
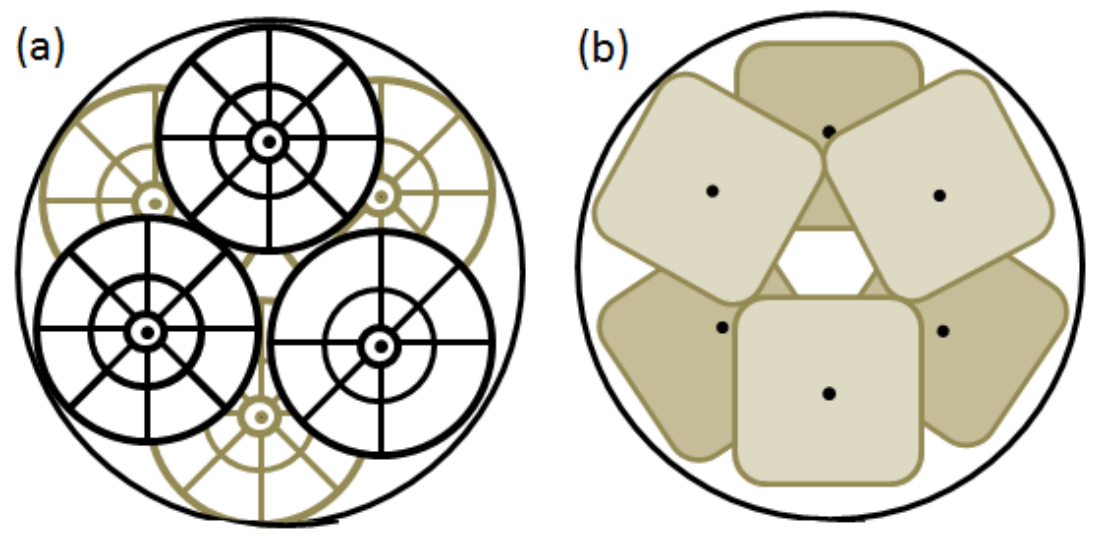

Fonte: Elaboração própria

Com o auxílio de bombas dosadoras Grundfos, o sistema contava com uma linha de recirculação do efluente, sendo que a velocidade ascensional exercida pela recirculação variou ao longo da operação (ver itens 4.1.3 e 4.1.4).

A fim de evitar perda de sulfeto da amostra líquida, optou-se por realizar as coletas em um septo submerso (FIGURA 3) em ambos os reatores. Amostradores ao longo do leito estruturado facilitaram na coleta de amostras para perfil espacial do reator.

\subsubsection{INÓCULO DOS REATORES ACIDOGÊNICOS/SULFETOGÊNICOS}

\subsubsection{Reator acidogênico/sulfetogênico com material suporte de polietileno (RAS-PEBD)}

A etapa de inoculação baseou-se em lodo termofílico $\left(55^{\circ} \mathrm{C}\right.$; sólidos voláteis totais SVT = 139 g L-1) coletado em reator anaeróbio metanogênico do tipo UASB escala plena tratando vinhaça de cana-de-açúcar. O lodo termofílico foi diluído em água residuária sintética (proporção 1:4, em L) e bombeado para o reator em sistema fechado durante 15 dias, para fixação da biomassa no material suporte (PEBD). A relação $\mathrm{DQO} / \mathrm{SO}_{4}{ }^{2-}$ inicial fixada em $2,5\left(\mathrm{DQO}=5.000 \mathrm{mg} \mathrm{L}^{-1} \mathrm{e} \mathrm{SO}_{4}{ }^{2-}=2.000 \mathrm{mg} \mathrm{L}^{-1}\right)$. O conteúdo orgânico foi complementado 
nos dias 7 e 10, dosando etanol para que atingisse DQO de $5.000 \mathrm{mg} \mathrm{L}^{-1}$ e não houvesse limitação por ausência de substrato. $\mathrm{O}$ reator passou a ser operado no modo contínuo a partir do $16^{\circ}$ dia.

A re-inoculação foi realizada após 285 dias de operação, em um esforço para aumentar a atividade sulfetogênica do reator. Nesta etapa, $100 \mathrm{~mL}$ de lodo termofílico (tratando vinhaça) foram misturados com $200 \mathrm{~mL}$ de lodo mesofílico obtido a partir de um reator UASB em escala plena tratando água residuária de abatedouro de aves (STV $=316 \mathrm{mg} \mathrm{L}^{-1}-$ lodo concentrado). Durante a reinoculação, o meio foi suplementado com água residuária sintética fresca $\left(5 \mathrm{~L}, \mathrm{DQO}=10.000 \mathrm{mg} \mathrm{L}^{-1} \mathrm{e} \mathrm{SO}_{4}{ }^{2-}=4.000 \mathrm{mg} \mathrm{L}^{-1}\right)$. Semelhante à etapa de inoculação inicial, o sistema permaneceu fechado por 15 dias, sendo posteriormente alimentado no modo contínuo com água residuária sintética fresca.

A opção por utilizar um lodo mesofílico se deu pelo sucesso na aplicação em trabalhos anteriores (Damianovic, Sakamoto, \& Foresti, 2006; Rodriguez, Oliveira, Raimundi, \& Zaiat, 2012; Sakamoto, Pozzi, Del Nery, Okada, \& Varesche, 2016; Sakamoto, Maintinguer, Hirasawa, Adorno, \& Varesche, 2012), cuja finalidade era o estabelecimento de um sistema sulfetogênico, sob condições mesofílicas. Penteado (2016) utilizou o mesmo inóculo em reatores mesofílico e termofílico, de modo que o desempenho dos reatores e as análises de biologia molecular indicaram a presença de organismos termofílico, como o gênero dos Thermoanaerobacterium e Bacillus. Devido à dificuldade na granulação do lodo termofílico em reator UASB, Syutsubo et al. (1997) utilizaram lodo mesofílico proveniente do tratamento de água residuária de indústria de processamento de fruta, atingindo $85 \%$ na remoção de DQO sob COV de $30 \mathrm{~kg}$-DQO $\mathrm{m}^{-3} \mathrm{~d}^{-1}$.

\subsubsection{Reator acidogênico/sulfetogênico com suporte de espuma de poliuretano $\left(R_{A S-P U}\right)$}

A etapa de partida do reator acidogênico/sulfetogênico seguiu com uma mistura de lodo mesofílico e termofílico (mesmos utilizados no reator com PEBD), na proporção $1 \mathrm{~L}$ de lodo termofílico : $300 \mathrm{~mL}$ de lodo mesofílico em $4 \mathrm{~L}$ de meio sintético, com DQO = 5.000 $\mathrm{mg} \mathrm{L}^{-1} \mathrm{e} \mathrm{SO}_{4}{ }^{2-}=2.000 \mathrm{mg} \mathrm{L}^{-1}$, sendo mantido sob recirculação por 15 dias (protocolo descrito no item 4.1.2.1).

\subsubsection{FASES OPERACIONAIS DO REATOR ACIDOGÊNICO/SULFETOGÊNICO COM POLIETILENO ( $\left.\mathrm{R}_{\mathrm{AS}-\mathrm{PEBD}}\right)$}

A operação do reator foi dividida em 13 subetapas, baseada na aplicação de diferentes estratégias (FIGURA 5), tais como carga de sulfato volumétrica (CSV), carga orgânica 
volumétrica $(\mathrm{COV})$, tempo de detenção hidráulica $(\mathrm{TDH})$, velocidade ascensional controlada principalmente pela recirculação do sistema, para incremento e maturação da atividade sulfetogênica no sistema. Detalhes operacionais estão expressos na Tabela 2. A operação do reator foi dividida em cinco principais etapas: 1) adaptação do sistema sulfetogênico; 2) avaliação da influência de recirculação; 3) restabelecimento do sistema; 4) minimização da concentração de sulfato no efluente e 5) redução da carga orgânica volumétrica. Todos os experimentos foram conduzidos em temperatura termofílica, sob $55^{\circ} \mathrm{C}$.

FIGURA 5 - Fluxograma geral das condições operacionais aplicadas ao reator acidogênico/sulfetogênico utilizando PEBD como material suporte, tendo como principais variáveis acarga de sulfato volumétrica $(\mathrm{CSV})$, velocidade ascensional $\left(\mathrm{V}_{\mathrm{a}}\right)$ e carga orgânica volumétrica $(\mathrm{COV})$

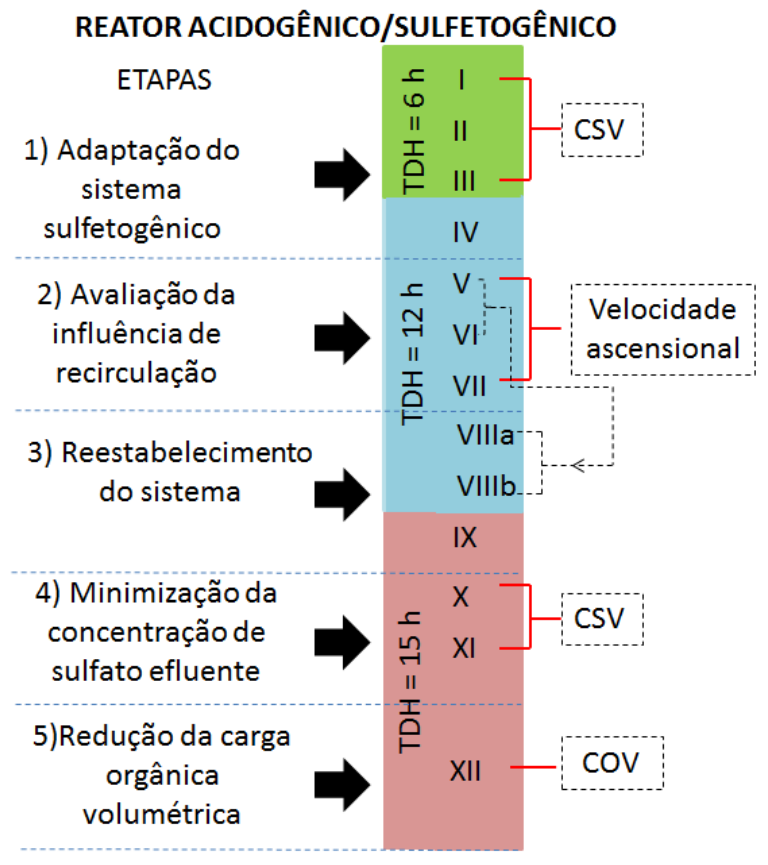

Fonte: Elaboração própria 
Tabela 2 - Parâmetros operacionais aplicados ao reator acidogênico/sulfetogênico com PEBD como material suporte ( $\left.\mathrm{R}_{\mathrm{AS}-\mathrm{PEBD}}\right)$

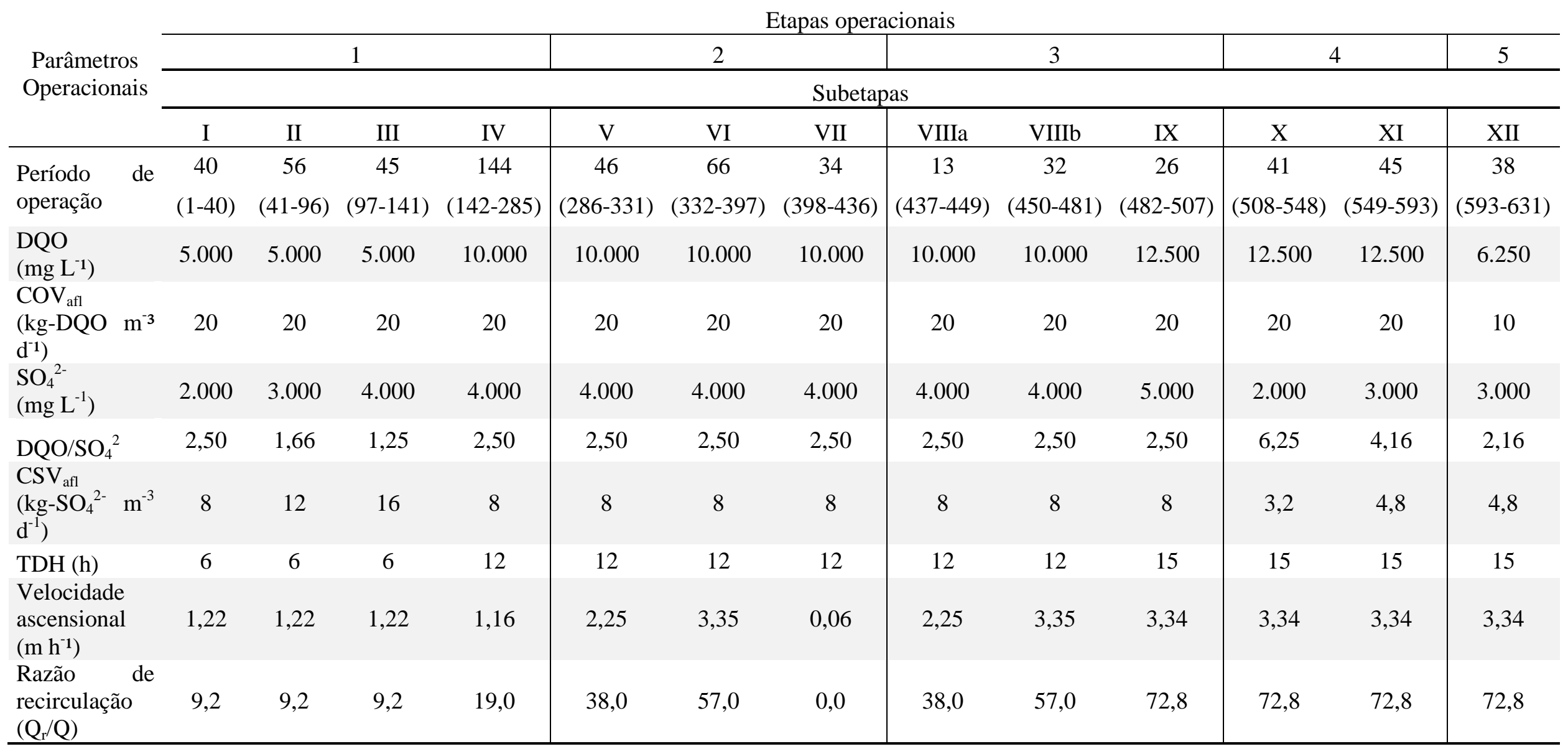




\subsubsection{Adaptação do sistema sulfetogênico (ETAPA 1)}

A etapa 1 teve como objetivo a adaptação da biomassa a um sistema sulfetogênico. Estratégias operacionais foram aplicadas nas subetapas de I à IV para estabilização do processo. A COV afl permaneceu em $20 \mathrm{~kg}-\mathrm{DQO} \mathrm{m}^{-3} \mathrm{~d}^{-1}$, DQO $=5.000 \mathrm{mg} \mathrm{L}^{-1} \mathrm{em} \mathrm{TDH}=6 \mathrm{~h}$ (subetapas I à III) e DQO $=10.000 \mathrm{mg} \mathrm{L}^{-1} \mathrm{em} \mathrm{TDH}=12 \mathrm{~h}$ (subetapa IV).

Como estratégia, adotou-se a variação da carga de sulfato afluente, sendo testadas 8 ,

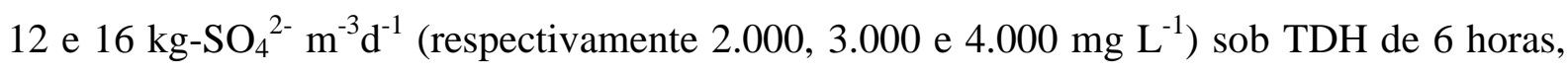
nas subetapas de I-III.

Para a subetapa IV, o TDH aumentou de 6 para 12 horas, sendo mantida a concentração de sulfato afluente. Com alteração do TDH, houve redução da carga de sulfato afluente de 16 para $8 \mathrm{~kg}-\mathrm{SO}_{4}{ }^{2-} \mathrm{m}^{-3} \mathrm{~d}^{-1}$, com o intuito de manter a concentração aplicada na fase III.

A fim de favorecer a mistura do meio reacional e diluição de aproximadamente $10 \mathrm{a}$ 20 vezes a vazão afluente, aplicou-se a recirculação da fase líquida resultando em uma velocidade ascensional de $1,15 \mathrm{~m} \mathrm{~h}^{-1}$ (velocidade exercida pela somatória da velocidade de recirculação e alimentação do sistema) e razão de recirculação (Qr/Q) de 9,2 (subetapas I à III) e 19,0 (subetapas IV).

\subsubsection{Avaliação da influência de recirculação (ETAPA 2)}

As subetapas de V à VII destinaram-se a avalição da influência de diferentes razões de recirculação na remoção de sulfato, recirculação do sulfeto e verificação na transferência de fase do sulfeto (líquida/gasosa).

Razões de recirculação de 38,0; 57,0 e 0 foram aplicadas respectivamente às subetapas V, VI e VII, cujas velocidades ascensionais foram de 2,25; 3,35 e $0,06 \mathrm{~m} \mathrm{~h}^{-1}$.

O TDH de 12 horas, carga de sulfato de $8 \mathrm{~kg}_{-} \mathrm{SO}_{4}{ }^{2-} \mathrm{m}^{-3} \mathrm{~d}^{-1}$ e $\mathrm{COV}_{\mathrm{afl}}$ de $20 \mathrm{~kg}$-DQO m ${ }^{3} \mathrm{~d}^{-1}$ foram parâmetros fixados para essas três etapas de recirculação do efluente.

\subsubsection{Restabelecimento do sistema (ETAPA 3)}

Essa etapa destinou-se as subetapas VIIIa, VIIIb e IX do reator acidogênico/sulfetogênico de PEBD. 
Após os testes realizados durante a etapa 2, subetapas V, VI e VII, optou-se por um período de transição, aumentando a recirculação de forma progressiva, inicialmente com velocidade ascensional de 2,25 $\mathrm{m} \mathrm{h}^{-1}\left(\mathrm{Qr} / \mathrm{Q}=38,0\right.$, VIIIa) e 3,35 $\mathrm{m} \mathrm{h}^{-1}$ ( $\mathrm{Qr} / \mathrm{Q}=57,0, \mathrm{VIII}$ ) (Tabela 2).

Na subetapa IX, o TDH passou de 12 para 15 horas $(\mathrm{Va}=3,34, \mathrm{Qr} / \mathrm{Q}=72,8$, fase IX, Tabela 2). Foram mantidas as $\operatorname{COV}_{\mathrm{afl}}\left(20 \mathrm{~kg}-\mathrm{DQO} \mathrm{m}^{-3} \mathrm{~d}^{-1}\right)$ e $\mathrm{CSV}_{\mathrm{afl}}\left(8 \mathrm{~kg}-\mathrm{SO}_{4}{ }^{2-} \mathrm{m}^{-3} \mathrm{~d}^{-1}\right)$.

\subsubsection{Minimização da concentração de sulfato no efluente (ETAPA 4)}

Essa etapa experimental consistiu na verificação da melhor eficiência de remoção de sulfato no reator de primeira fase, para que o efluente fosse aplicado em um reator metanogênico. A diminuição da concentração do sulfato residual no efluente visava a conversão quase completa do sulfato a sulfeto e sua remoção da fase líquida para alimentação do reator metanogênico (segunda fase), em que se esperava biogás com baixa concentração de sulfeto. Entre as estratégias operacionais aplicadas, encontra-se a variação na

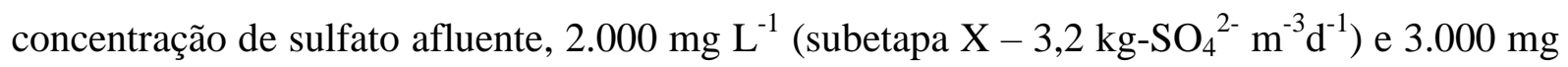
$\mathrm{L}^{-1}$ (subetapa XI - 4,8 $\mathrm{kg}_{-} \mathrm{SO}_{4}{ }^{2-} \mathrm{m}^{-3} \mathrm{~d}^{-1}$ ).Para essa etapa, adotou-se o TDH de $15 \mathrm{~h}$ e velocidade de recirculação de $3,34 \mathrm{~m} \mathrm{~h}^{-1}(\mathrm{Qr} / \mathrm{Q}=72,8$, subetapa $\mathrm{IX}$ - Tabela 2).

\subsubsection{Redução da carga orgânica volumétrica aplicada (ETAPA 5)}

Todas as etapas anteriores mantiveram fixa a carga orgânica volumétrica aplicada em $20 \mathrm{~kg} \mathrm{~m}^{-3} \mathrm{~d}^{-1}$. Esta etapa visou reduzir a $\mathrm{COV}_{\text {afl }}$ de 20 para $10 \mathrm{~kg} \mathrm{~m}^{-3} \mathrm{~d}^{-1}$, a fim de verificar a influência na remoção de sulfato, remoção de matéria orgânica e composição do biogás em uma COV mais baixa.

Os demais parâmetros, como carga de sulfato, velocidade ascensional e TDH foram mantidos como na subetapa XI (etapa 4).

\subsubsection{FASES OPERACIONAIS DO REATOR ACIDOGÊNICO/SULFETOGÊNICO COM SUPORTE DE ESPUMA DE POLIURETANO ( $\left.\mathrm{R}_{\mathrm{AS}-\mathrm{PU}}\right)$}

A operação do reator acidogênico/sulfetogênico com espuma poliuretano como material suporte consistiu em utilizar estratégias a fim de favorecer adaptação da biomassa mais rápida que a observada quando de utilizou PEBD como suporte, como alteração da carga orgânica volumétrica, carga de sulfato volumétrica, TDH e razão de recirculação. As condições operacionais basearam-se no comportamento do $\mathrm{R}_{\mathrm{AS}-\mathrm{PEBD}}$. A operação do $\mathrm{R}_{\mathrm{AS}-\mathrm{PU}}$ foi dividida em quatro etapas: I) inicialmente aplicou-se a carga de sulfato de $8 \mathrm{~kg}-\mathrm{SO}_{4}{ }^{2-} \mathrm{m}^{-3} \mathrm{~d}^{-1}$, 
DQO/ $\mathrm{SO}_{4}{ }^{2-}$ de 2,5 e velocidade ascensional de $3,42 \mathrm{~m} \mathrm{~h}^{-1}$; II) redução da carga de sulfato

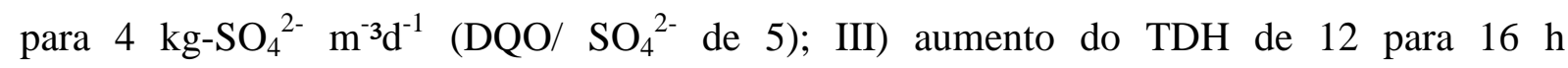
(consequentemente redução da $\mathrm{COV}_{\mathrm{afl}}$ para $15 \mathrm{~kg}$-DQO $\mathrm{m}^{-3} \mathrm{~d}^{-1}$ e velocidade ascensional para $5,66 \mathrm{~m} \mathrm{~h}^{-1} ; \mathrm{IV}$ ) aumento da velocidade ascensional para 7,90 $\mathrm{m} \mathrm{h}^{-1}$.

Tabela 3 - Parâmetros operacionais aplicados ao reator acidogênico/sulfetogênico com espuma de poliuretano

\begin{tabular}{|c|c|c|c|c|}
\hline \multirow{2}{*}{ Parâmetros Operacionais } & \multicolumn{4}{|c|}{ Etapas operacionais } \\
\hline & I & II & III & IV \\
\hline Período de operação & $45(1-45)$ & $90(46-136)$ & $31(137-168)$ & $59(169-228)$ \\
\hline DQO (mg L'-1) & 10.000 & 10.000 & 10.000 & 10.000 \\
\hline $\mathrm{COV}_{\mathrm{afl}}\left(\mathrm{kg}-\mathrm{DQO} \mathrm{m}^{-3} \mathrm{~d}^{-1}\right)$ & 20 & 20 & 15 & 15 \\
\hline $\mathrm{SO}_{4}^{2-}\left(\mathrm{mg} \mathrm{L}^{-1}\right)$ & 4.000 & 2.000 & 2.500 & 2.500 \\
\hline $\mathrm{CSV}_{\mathrm{afl}}\left(\mathrm{kg}_{-} \mathrm{SO}_{4}{ }^{2-} \mathrm{m}^{-3} \mathrm{~d}^{-1}\right)$ & 8 & 4 & 4 & 4 \\
\hline TDH (h) & 12 & 12 & 16 & 16 \\
\hline Velocidade ascensional $\left(\mathrm{m} \mathrm{h}^{-1}\right)$ & 3,42 & 3,42 & 5,66 & 7,90 \\
\hline Razão de recirculação & 65,8 & 65,8 & 125,6 & 164,3 \\
\hline
\end{tabular}

Fonte: Elaboração própria

\subsection{Fase metanogênica}

\subsubsection{REATORES BIOLÓGICOS METANOGÊNICO DE SEGUNDA FASE E FASE ÚNICA}

$\mathrm{Na}$ etapa que visava a produção de metano, comparou-se a eficiência de um sistema metanogênico de segunda fase $\left(\mathrm{R}_{\mathrm{MI}}\right)$ e um de fase única $\left(\mathrm{R}_{\mathrm{MII}}\right)$. Os reatores de leito estruturado foram construído em tubo de acrílico, com dimensões de 61,5 mm de diâmetro interno, $820 \mathrm{~mm}$ de altura total, sendo $15 \mathrm{~cm}$ da câmara de alimentação, $50,5 \mathrm{~cm}$ de leito estruturado e 16,5 da câmara de saída, totalizando um volume útil de 1,29 $\mathrm{L}$ para $\mathrm{R}_{\mathrm{MI}}$ e 1,52 $\mathrm{R}_{\mathrm{MII}}$. As estruturas de acrílico utilizadas nessa fase foram as mesmas dos reatores acidogênicos.

Como material suporte aplicou-se cubos de espuma de PU, com dimensões em torno de 2,5 $\times 2,5 \times 2,5 \mathrm{~cm}$ para adesão da biomassa, assim como esquematizado na FIGURA 4-b.

Devido a problemas técnicos, o aparato experimental não contou com medidor para o volume de biogás nos reatores metanogênicos. 
FIGURA 6 - Representação esquemática do aparato experimental utilizado na fase metanogênica: 1- reservatório de efluente sintético, 2 - bomba peristáltica para alimentação, 3 - câmara de entrada do afluente, 4 - região reacional (leito estruturado), 5- amostradores (AE), 6 - câmara de saída do efluente, 7 - septo para amostragem da fase líquida, 8 - saída do efluente, 9 - saída do biogás, 10 - selo hídrico.

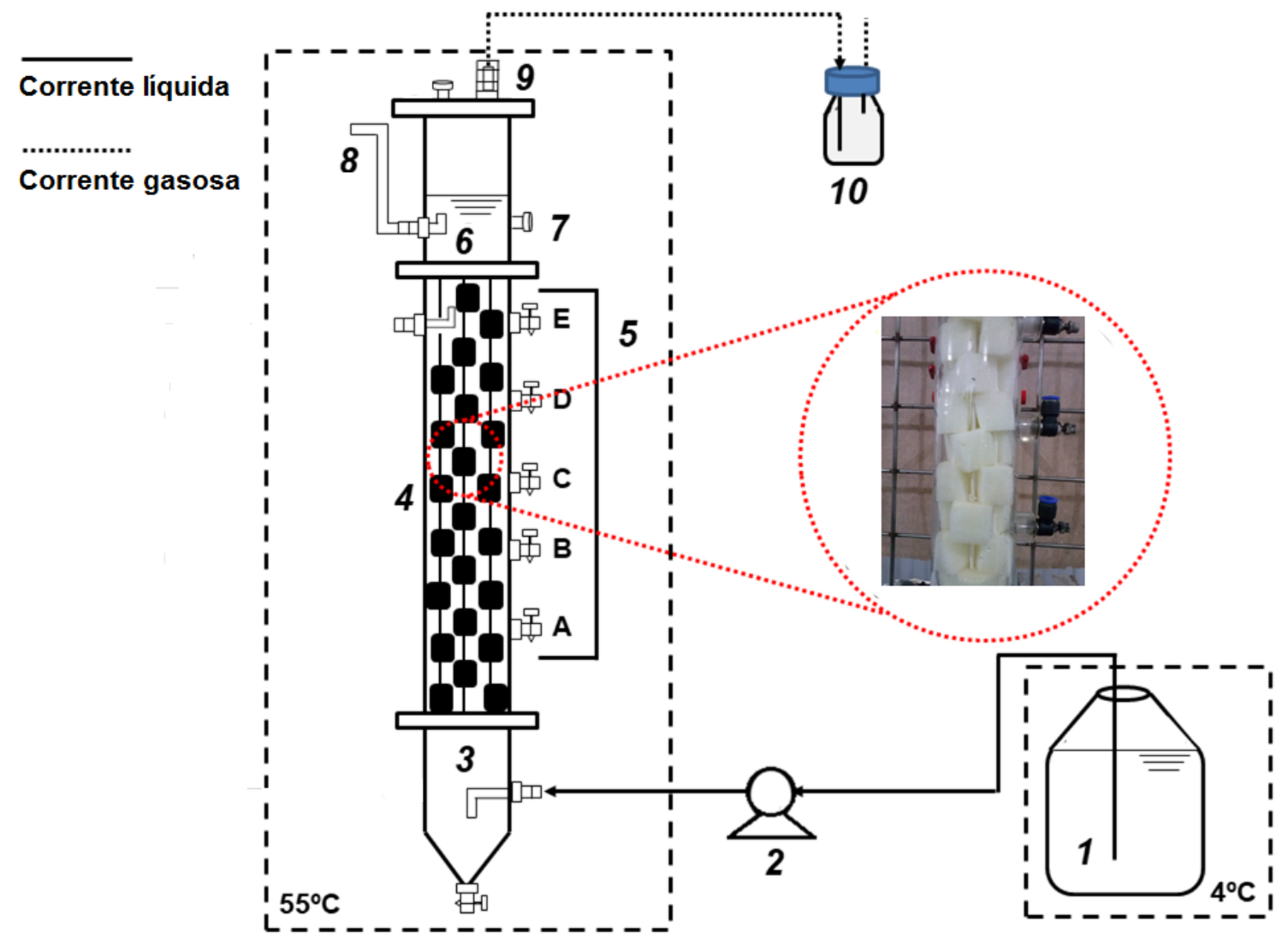

Fonte: Elaboração própria

\subsubsection{INÓCULO DOS REATORES METANOGÊNICO DE SEGUNDA FASE E FASE} ÚNICA ( $\left.\mathrm{R}_{\mathrm{MI}} \mathrm{E} \mathrm{R}_{\mathrm{MII}}\right)$

Essa etapa consistiu na mistura de quatro tipos de lodo, provenientes de reatores anaeróbios metanogênico, sendo dois de abatedouros de aves (mesofílico) e dois tratando vinhaça de cana-de-açúcar (escala plena/termofílico e piloto/mesofílico). A proporção preparada obedecia às proporções de: $1500 \mathrm{~mL}$ de lodo termofílico (escala plena), $500 \mathrm{~mL}$ de lodo mesofílico (escala piloto) e $500 \mathrm{~mL}$ de lodo proveniente de abatedouro de aves. Juntamente ao lodo, adicionou-se $500 \mathrm{~mL}$ de água para a diluição.

O blend de lodos visava aumentar a diversidade microbiana do reator, direcionando para uma condição favorável ao estabelecimento de um sistema metanogênico. A mistura de lodo resultou em $79 \mathrm{~g} \mathrm{~L}^{-1}$ de sólidos totais voláteis. 
Após a montagem e colocação do meio suporte nos reatores metanogênico, os mesmos foram preenchidos com a mistura de lodo, mantendo as espumas submersas por $6 \mathrm{~h}$. Decorrido esse período, o lodo em excesso foi drenado e o reator preenchido com o meio sintético (ver item 4.3.3), cuja composição obedeceu às dosagens utilizadas na fase I de cada um dos reatores $\left(\mathrm{R}_{\mathrm{MI}}\right.$ e $\mathrm{R}_{\mathrm{MII}}$ ), aplicado a primeira etapa de operação, com CO de 2,5 g-DQO d ${ }^{-1}$ (ver item 4.3).

\subsubsection{FASES OPERACIONAIS DO REATOR METANOGÊNICO DE SEGUNDA FASE $\left(\mathrm{R}_{\mathrm{MI}}\right)$}

Algumas estratégias operacionais (Tabela 4) foram adotadas conforme o desempenho do reator. Para $\mathrm{R}_{\mathrm{MI}}$, foram testadas as cargas de 2,5; 3,5 e 5,0 $\mathrm{g} \mathrm{d}^{-1}$, respectivamente etapas I, II e III, com TDH de 11,46 h (TDH teórico) para todas as fases testadas. Entre os dias 11 e 25, o reator foi mantido sob recirculação para adaptação das biomassa às condições estabelecidas.

Tabela 4 - Condições operacionais para o reator metanogênico de segunda fase $\left(\mathrm{R}_{\mathrm{MI}}\right)$

\begin{tabular}{lcccc}
\hline Etapas & Adaptação & I & II & III \\
\hline Tempo de operação & $25(1-25)$ & $17(26-43)$ & $30(44-74)$ & 27 (75-102) \\
DQO $\left(\mathrm{mg} \mathrm{L}^{-1}\right)$ & 1050 & 1050 & 1470 & 2100 \\
$\mathrm{SO}_{4}^{2-}\left(\mathrm{mg} \mathrm{L}^{-1}\right)$ & 12 & 24 & 24 & 24 \\
Carga orgânica $\left(\mathrm{g} \mathrm{d}^{-1}\right)$ & 2,5 & 2,5 & 3,5 & 5,0 \\
$\mathrm{TDH}^{*}(\mathrm{~h})$ & \multicolumn{3}{c}{11,46} \\
\hline
\end{tabular}

*TDH teórico

As etapas I e II foram etapas estratégicas para o aumento gradativo da carga orgânica, até que atingisse a carga final pretendida de $5 \mathrm{~g} \mathrm{~d}^{-1}$. Como critério para seu aumento, era utilizada a eficiência de remoção da DQO (aproximadamente 90\%)

\subsubsection{FASES OPERACIONAIS DO REATOR DE FASE ÚNICA $\left(\mathrm{R}_{\mathrm{MII}}\right)$}

Em $\mathrm{R}_{\mathrm{MII}}$, as cargas aplicadas ao reator foram 0,$625 ; 1,25 ; 2,5$ e 5,0 $\mathrm{g}$-DQO d $\mathrm{d}^{-1}$, divididas em seis etapas, com TDH de 16,5 h para todas as etapas testadas. Esse TDH foi ajustado conforme a carga orgânica imposta para início dos teste $\left(2,5\right.$ g-DQO d $\left.{ }^{-1}\right)$, sendo esse parâmetro fixado para todas as fases (mais detalhes da definição de como foram consideradas as CO para os reatores de fase única e segunda fase estão descritos no item 4.4.3).

As estratégias operacionais adotadas ao longo da operação, assim como RM em consideração a matéria orgânica removida para a alteração das cargas orgânicas, visando atingir $5 \mathrm{~g} \mathrm{~d}^{-1}$. 
Tabela 5 - Condições operacionais para o reator de fase única $\left(\mathrm{R}_{\mathrm{MII}}\right)$

\begin{tabular}{lcccccc}
\hline Etapas & I & II & III & IV & V & VI \\
\hline Tempo de operação & 42 & 34 & 28 & 4 & 6 & 21 \\
& $(1-42)$ & $(43-77)$ & $(78-106)$ & $(107-111)$ & $(112-118)$ & $(119-140)$ \\
DQO $\left(\mathrm{mg} \mathrm{L}^{-1}\right)$ & 1.250 & 313 & 625 & 1.250 & 2.500 & 2.500 \\
$\mathrm{SO}_{4}^{2-}\left(\mathrm{mg} \mathrm{L}^{-1}\right)$ & 400 & 100 & 200 & 200 & 200 & 400 \\
Carga orgânica $\left(\mathrm{g} \mathrm{d}^{-1}\right)$ & 2,5 & 0,625 & 1,25 & 2,5 & 5 & 5 \\
TDH (h) & & & & 16,5 & & \\
\hline
\end{tabular}

\subsection{Fluxograma geral do trabalho}

Para uma visualização geral do presente trabalho, a FIGURA 7 reúne todas as etapas de operação dos quatro reatores e a relação entre a primeira e segunda fase de tratamento adotada. A justificativa quanto à escolha da subetapa $X$ do $R_{A S-P E B D}$ para aplicação no reator de segunda fase estão descritas a discussão dos resultados no item 5.1.

FIGURA 7 - Fluxograma de tratamento do presente trabalho, contemplando os reatores acidogênicos/sulfetogênico de primeira fase $\left(\mathrm{R}_{\mathrm{AS}-\mathrm{PEBD}}\right.$ e $\left.\mathrm{R}_{\mathrm{AS}-\mathrm{PU}}\right)$ e os reatores metanogênico de segunda fase $\left(\mathrm{R}_{\mathrm{MI}}\right)$ e de fase única $\left(\mathrm{R}_{\mathrm{MII}}\right)$.

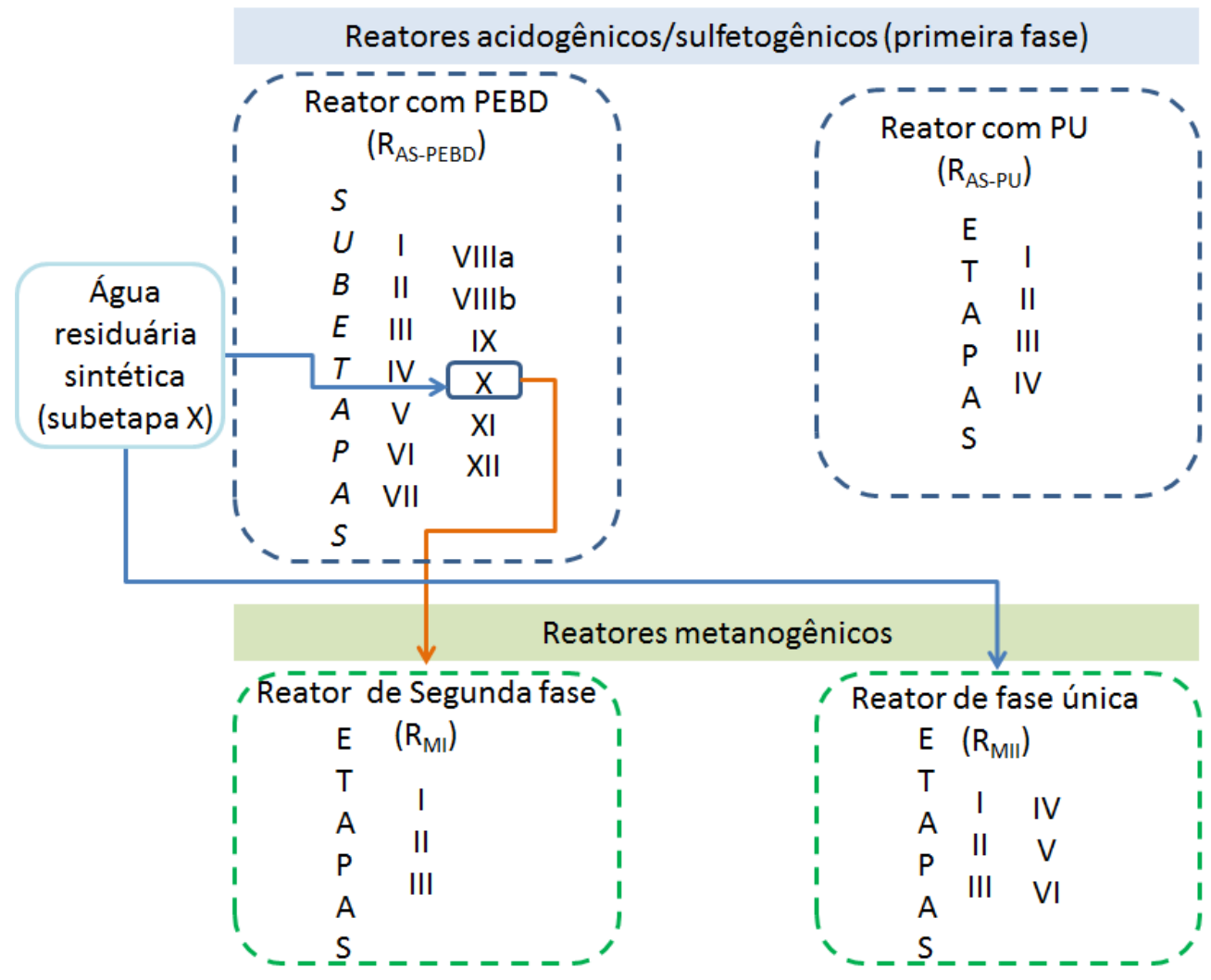

Fonte: Elaboração própria 


\section{4 Água residuária sintética}

A água residuária utilizada baseou-se na caracterização de algumas vinhaças de canade-açúcar (principalmente quanto à constituição da fração inorgânica) do estado de São Paulo, seguindo composição proposta por Godoi et al.(2017) para o preparo das soluções estoque. Como o foco do trabalho é uma exploração fundamental, optou-se em aplicar apenas etanol como única fonte de carbono. O intuito foi reduzir o número de interferentes, de forma que facilite o entendimento do processo. Vale ressaltar que para esse trabalho, o objetivo não foi formular uma água residuária sintética simulando a vinhaça e sim basear-se em sua composição para formulação de uma água sintética composta por constituintes de interesse, sulfato e matéria orgânica, aqui retratada como DQO.

Soluções estoque de metais, sais, nutrientes, vitaminas e complementação de micronutrientes auxiliaram na preparação da água residuária sintética.

\subsubsection{SOLUÇÕES ESTOQUE}

A fim de facilitar a dosagem de todos os componentes da água residuária sintética, foram preparadas solução estoque de metais, sais, nutrientes, complementação de micronutrientes adaptado de Torres (1992) e vitaminas (Touzel \& Albagnac, 1983), descrita na Tabela 6.

Como elementos adicionados, utilizaram-se ferro, manganês, zinco, cobre, níquel, chumbo e cádmio na solução de metais, cálcio e magnésio na solução de sais, nitrogênio e fósforo nos nutrientes e cobalto, bório, molibdato e selenito como complementação de micronutrientes..

A dosagem de cada solução variou conforme as fases de operação de cada reator e estão descritos nos itens 4.4.2 e 4.4.3. 
Tabela 6 - Solução estoque para preparo de água residuária sintética

\begin{tabular}{|c|c|c|}
\hline Solução & Reagente & $\left(\mathrm{g} \mathrm{L}^{-1}\right)$ \\
\hline \multirow{7}{*}{$\frac{\pi}{\pi}$} & Cloreto Férrico hexaidratado $\left(\mathrm{FeCl}_{3} \cdot 6 \mathrm{H}_{2} \mathrm{O}\right)$ & 7,56 \\
\hline & Cloreto de Manganês tetraidratado $\left(\mathrm{MnC}_{12} \cdot 4 \mathrm{H}_{2} \mathrm{O}\right)$ & 1,55 \\
\hline & Cloreto de Zinco Anidro $\left(\mathrm{ZnCl}_{2}\right.$ anidro $)$ & 0,14 \\
\hline & Cloreto de Cobre dihidratado $\left(\mathrm{CuCl}_{2} \cdot 2 \mathrm{H}_{2} \mathrm{O}\right)$ & 0,13 \\
\hline & Cloreto de Níquel hexaidratado $\left(\mathrm{NiCl}_{2} \cdot 6 \mathrm{H}_{2} \mathrm{O}\right)$ & 0,11 \\
\hline & Cloreto de Chumbo $\left(\mathrm{PbCl}_{2}\right)$ & 0,06 \\
\hline & Cloreto de Cádmio hidratado $\left(\mathrm{CdCl}_{2} \cdot \mathrm{H}_{2} \mathrm{O}\right)$ & 0,02 \\
\hline \multirow{2}{*}{$\stackrel{n}{\tilde{m}}$} & Cloreto de Cálcio dihidratado $\left(\mathrm{CaCl}_{2} \cdot 2 \mathrm{H}_{2} \mathrm{O}\right)$ & 122,28 \\
\hline & Cloreto de Magnésio hexaidratado $\left(\mathrm{MgCl}_{2} \cdot 6 \mathrm{H}_{2} \mathrm{O}\right)$ & 168,03 \\
\hline \multirow{2}{*}{$\stackrel{\mathscr{E}}{\Xi} \stackrel{\mathscr{O}}{\Xi}$} & Cloreto de Amónio $\left(\mathrm{NH}_{4} \mathrm{Cl}\right)$ & 175,71 \\
\hline & Hidrogenofostafo de Potássio $\left(\mathrm{KH}_{2} \mathrm{PO}_{4}\right)$ & 15,81 \\
\hline \multirow{4}{*}{ 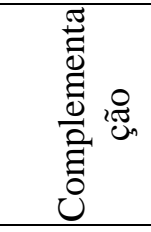 } & Dicloreto de Cobalto hexaidratado $\left(\mathrm{CoCl}_{2} \cdot 6 \mathrm{H}_{2} \mathrm{O}\right)$ & 0,024 \\
\hline & Ácido Bórico $\left(\mathrm{H}_{3} \mathrm{BO}_{3}\right)$ & 0,010 \\
\hline & Molibdato de Sódio hidratado $\left(\mathrm{NaMoO}_{4} \cdot \mathrm{H}_{2} \mathrm{O}\right)$ & 0,024 \\
\hline & Selenito de Sódio pentaidratado $\left(\mathrm{Na}_{2} \mathrm{SeO}_{3} .5 \mathrm{H}_{2} \mathrm{O}\right)$ & 0,026 \\
\hline \multirow{10}{*}{$\begin{array}{l}\stackrel{\mathscr{\Xi}}{\Xi} \\
\stackrel{\Xi}{\Xi} \\
\stackrel{\Xi}{\Xi}\end{array}$} & Biotina & 0,002 \\
\hline & Ácido Fólico & 0,002 \\
\hline & Tiamina $\mathrm{HCl} .2 \mathrm{H}_{2} \mathrm{O}$ & 0,005 \\
\hline & Riboflavina & 0,005 \\
\hline & Ácido Nicotínico $\left(\mathrm{C}_{6} \mathrm{H}_{5} \mathrm{NO}_{2}\right)$ & 0,005 \\
\hline & Pantotenato de Cálcio & 0,005 \\
\hline & Piridoxina $\mathrm{HCl}$ (Pyridoxolhydrochlorid $-\mathrm{C}_{8} \mathrm{H}_{12} \mathrm{ClNO}_{3}$ ) & 0,01 \\
\hline & Vitamina B12 (Cyanocobalamin) & 0,0001 \\
\hline & Ácido Lipóico (Ácido thióico) & 0,005 \\
\hline & Ácido p-aminobenzóico & 0,005 \\
\hline
\end{tabular}

\subsection{2 ÁGUA RESIDUÁRIA SINTÉTICA PARA OS REATORES ACIDOGÊNICOS/SULFETOGÊNICOS}

Para o preparo da água sintética dos reatores acidogênicos/sulfetogênico utilizou-se etanol como única fonte de carbono fornecida, sendo dosado de acordo com a DQO definida para cada uma das fases. $\mathrm{O}$ pH afluente ajustado em torno de 7,0 com a adição de $\mathrm{NaOH} / \mathrm{HCl}$, sem que houvesse complementação com bicarbonato de sódio.

$\mathrm{O}$ sulfato se dava por meio da adição de sulfato de sódio $\left(\mathrm{Na}_{2} \mathrm{SO}_{4}\right)$, obedecendo à concentração estabelecida em cada uma das fases testadas durante a operação. As dosagens utilizadas em cada um dos reatores acidogênicos/sulfetogênico estão descritas nas Tabelas 7 e 8. 
Tabela 7 - Água residuária sintética para o reator acidogênico/sulfetogênico com PEBD como material suporte ( $\left.\mathrm{R}_{\mathrm{AS}-\mathrm{PEBD}}\right)$

\begin{tabular}{|c|c|c|c|c|c|c|c|c|c|c|c|c|}
\hline \multirow{4}{*}{ Constituintes } & \multicolumn{12}{|c|}{ Etapas operacionais } \\
\hline & \multicolumn{4}{|c|}{1} & \multicolumn{3}{|c|}{2} & \multicolumn{2}{|c|}{3} & \multicolumn{2}{|c|}{4} & \multirow[t]{2}{*}{5} \\
\hline & \multicolumn{11}{|c|}{ Subetapas } & \\
\hline & $\mathrm{I}$ & II & III & IV & $\mathrm{V}$ & VI & VII & $\mathrm{VIII}_{\mathrm{a} / \mathrm{b}}{ }^{*}$ & IX & $\mathrm{X}$ & XI & XII \\
\hline $\mathrm{DQO}_{\text {etanol }}\left(\mathrm{mg} \mathrm{L}^{-1}\right)$ & 5.000 & 5.000 & 5.000 & 10.000 & 10.000 & 10.000 & 10.000 & 10.000 & 12.500 & 12.500 & 12.500 & 6.250 \\
\hline $\mathrm{SO}_{4}^{2-}\left(\mathrm{mg} \mathrm{L}^{-1}\right)$ & 2.000 & 3.000 & 4.000 & 4.000 & 4.000 & 4.000 & 4.000 & 4.000 & 5.000 & 2.000 & 3.000 & 3.000 \\
\hline Metais $\left(\mathrm{mL} \mathrm{L}^{-1}\right)$ & 0,75 & 0,75 & 0,75 & 1,5 & 1,5 & 1,5 & 1,5 & 1,5 & 1,875 & 1,875 & 1,875 & 1,875 \\
\hline Sais $\left(\mathrm{mL} \mathrm{L}^{-1}\right)$ & 1,5 & 1,5 & 1,5 & 3,0 & 3,0 & 3,0 & 3,0 & 3,0 & 3,75 & 3,75 & 3,75 & 3,75 \\
\hline Nutrientes $\left(\mathrm{mL} \mathrm{L}^{-1}\right)$ & 2,25 & 2,25 & 2,25 & 4,5 & 4,5 & 4,5 & 4,5 & 4,5 & 5,625 & 5,625 & 5,625 & 5,625 \\
\hline Complementação $\left(\mathrm{mL} \mathrm{L}^{-1}\right)$ & 1,0 & 1,0 & 1,0 & 1,0 & 1,0 & 1,0 & 1,0 & 1,0 & 1,0 & 1,0 & 1,0 & 1,0 \\
\hline Vitaminas $\left(\mathrm{mL} \mathrm{L}^{-1}\right)$ & 1,0 & 1,0 & 1,0 & 1,0 & 1,0 & 1,0 & 1,0 & 1,0 & 1,0 & 1,0 & 1,0 & 1,0 \\
\hline
\end{tabular}

*Para a subetapas VIIIa e VIIIb utilizou-se a mesma constituição da água residuária sintética, variando apenas a taxa de recirculação.

Tabela 8 - Água residuária sintética para o reator acidogênico/sulfetogênico com material suporte de poliuretano ( $\left.\mathrm{R}_{\mathrm{AS} \text { - PU }}\right)$

\begin{tabular}{lcccc}
\hline \multicolumn{1}{c}{ Constituintes } & \multicolumn{4}{c}{ Etapas operacionais } \\
& I & II & III & IV \\
\hline DQO etanol $\left(\mathrm{mg} \mathrm{L}^{-1}\right)$ & 10.000 & 10.000 & 10.000 & 10.000 \\
$\mathrm{SO}_{4}{ }^{2-}\left(\mathrm{mg} \mathrm{L}^{-1}\right)$ & 4.000 & 2.000 & 2.500 & 2.500 \\
Metais $\left(\mathrm{mL} \mathrm{L}^{-1}\right)$ & 1,5 & 1,5 & 1,5 & 1,5 \\
Sais $\left(\mathrm{mL} \mathrm{L}^{-1}\right)$ & 3 & 3 & 3,0 & 3,0 \\
Nutrientes $\left(\mathrm{mL} \mathrm{L}^{-1}\right)$ & 4,5 & 4,5 & 4,5 & 4,5 \\
Complementação $\left(\mathrm{mL} \mathrm{L}^{-1}\right)$ & 1 & 1 & 1 & 1 \\
Vitaminas $\left(\mathrm{mL} \mathrm{L}^{-1}\right)$ & 1 & 1 & 1 & 1 \\
\hline
\end{tabular}




\subsection{3 ÁGUA RESIDUÁRIA SINTÉTICA PARA REATORES METANOGÊNICOS DE SEGUNDA FASE $\left(\mathrm{R}_{\mathrm{MI}}\right)$ e FASE ÚNICA $\left(\mathrm{R}_{\mathrm{MII}}\right)$}

A água residuária sintética aplicada aos reatores metanogênico mantiveram como característica comum à carga orgânica, sendo adotada para etapa de partida 2,5 g-DQO d ${ }^{-1}$.

Para o reator metanogênico de segunda fase $\left(\mathrm{R}_{\mathrm{MI}}\right)$, aplicou-se um efluente sintético, a partir de caracterização do efluente final referente à subetapa $X$ do reator acidogênico/sulfetogênico de PEBD ( $\mathrm{R}_{\mathrm{AS} \text {-PEBD}}$ ) (detalhes sobre a escolha do efluente da referida subetapa estão descritos da discussão dos resultados), de modo que além do etanol (fração não convertida no reator de primeira fase) como fonte orgânica houve a adição de ácido acético, como um produto gerado no reator de primeira fase. Optou-se pela preparação de um sintético, uma vez que não havia possibilidade de armazenar e preservar as características do efluente proveniente do reator de primeira fase.

Já o reator metanogênico de fase única recebeu como afluente o mesmo utilizado na alimentação do $\mathrm{R}_{\mathrm{AS} \text {-PEBD }}$ durante a subetapa $\mathrm{X}$, com o devido ajuste da carga orgânica para aplicação em reator de fase única, semelhante a carga aplicada no reator de segunda fase.

Em todas as etapas dos reatores metanogênico de segunda fase e fase única (respectivamente $\mathrm{R}_{\mathrm{MI}}$ e $\mathrm{R}_{\mathrm{MII}}$ ), a alcalinidade do meio foi mantida com a adição de bicarbonato de sódio na proporção de 1,2 g-NaOHCO $3 \mathrm{~g}^{-1}$-DQO (Döll \& Foresti, 2010).

A concentração de DQO efluente do reator acidogênico contava com uma DQO final de $10.500 \mathrm{mg} \mathrm{L}^{-1}$ (subetapa $\mathrm{X}-\mathrm{R}_{\mathrm{AS}-\mathrm{PEBD}}$ ). Para que fosse feita comparação entre os sistemas, uma relação entre a DQO do reator metanogênico de fase única $\left(R_{M I I}\right)$ e o reator metanogênico de segunda fase $\left(\mathrm{R}_{\mathrm{MI}}\right)$ foi determinada, sendo a concentração de DQO afluente para $\mathrm{R}_{\mathrm{MI}}=10.500 \mathrm{mg} \mathrm{L}^{-1}$ e $\mathrm{R}_{\mathrm{MII}}=12.500 \mathrm{mg} \mathrm{L}^{-1}$ (concentração aplicada ao reator de primeira fase). Desse modo $\mathrm{DQO}_{\mathrm{RMII}} / \mathrm{DQO}_{\mathrm{RMI}}=1,19$.

Aplicou-se essa relação para que fosse feito o ajuste de vazão para a carga orgânica definida para operação. Devido à limitação da bomba disponível para alimentação do sistema, optou-se em diluir essa concentração em 10 vezes, a fim de ajustar a carga orgânica de 2,5 gDQO d $\mathrm{d}^{-1}$.

Desse modo, diluindo a vazão de $\mathrm{R}_{\mathrm{MI}}$, obteve-se uma concentração de $1.050 \mathrm{mg} \mathrm{L}^{-1}$ (etanol e ácido acético). Assumindo a relação $\mathrm{DQO}_{\mathrm{RMI}} / \mathrm{DQO}_{\mathrm{RMI}}$, a concentração de DQO em 
$\mathrm{R}_{\mathrm{MII}}$ foi de $1250 \mathrm{mg} \mathrm{L}^{-1}$. A composição da água sintética pode ser consultada nas Tabelas $9 \mathrm{e}$ 10, respectivamente reator metanogênico se segunda fase e fase única.

Tabela 9 - Água residuária sintética para o reator metanogênico de segunda fase $\left(\mathrm{R}_{\mathrm{MI}}\right)$

\begin{tabular}{|c|c|c|c|c|}
\hline \multirow[b]{2}{*}{ Constituíntes } & \multicolumn{4}{|c|}{ Fases operacionais } \\
\hline & Adaptação & I & II & III \\
\hline $\mathrm{DQO}_{\text {total }}\left(\mathrm{mg} \mathrm{L}^{-1}\right)$ & 1.050 & 1.050 & 1.470 & 2.100 \\
\hline $\mathrm{DQO}_{\text {etanol }}\left(\mathrm{mg} \mathrm{L}^{-1}\right)$ & 874 & 874 & 1.223 & 1.747 \\
\hline $\mathrm{DQO}_{\mathrm{HAc}}\left(\mathrm{mg} \mathrm{L}^{-1}\right)$ & 177 & 177 & 247 & 353 \\
\hline $\mathrm{SO}_{4}^{2-}\left(\mathrm{mg} \mathrm{L}^{-1}\right)$ & 12 & 24 & 24 & 24 \\
\hline Metais $\left(\mathrm{mL} \mathrm{L}^{-1}\right)$ & 0,315 & 0,315 & 0,441 & 0,63 \\
\hline Sais $\left(\mathrm{mL} \mathrm{L}^{-1}\right)$ & 0,63 & 0,63 & 0,882 & 1,2599 \\
\hline Nutrientes $\left(\mathrm{mL} \mathrm{L}^{-1}\right)$ & 0,945 & 0,945 & 1,323 & 1,8899 \\
\hline Complementação $\left(\mathrm{mL} \mathrm{L}^{-1}\right)$ & 1,0 & 1,0 & 1,0 & 1 \\
\hline Vitaminas $\left(\mathrm{mL} \mathrm{L}^{-1}\right)$ & 1,0 & 1,0 & 1,0 & 1 \\
\hline Bicarbonato de sódio $\left(\mathrm{mg} \mathrm{L}^{-1}\right)$ & 1,26 & 1,26 & 1,76 & 2,52 \\
\hline
\end{tabular}

Tabela 10 - Água residuária sintética para o reator metanogênico de fase única $\left(\mathrm{R}_{\mathrm{MII}}\right)$

\section{Fases operacionais}

\begin{tabular}{|c|c|c|c|c|c|c|}
\hline Constituintes & I & II & III & IV & V & VI \\
\hline $\mathrm{DQO}_{\text {etanol }}\left(\mathrm{mg} \mathrm{L}^{-1}\right)$ & 1.250 & 313 & 625 & 1.250 & 2.500 & 2.500 \\
\hline $\mathrm{SO}_{4}^{2-}\left(\mathrm{mg} \mathrm{L}^{-1}\right)$ & 400 & 100 & 200 & 200 & 200 & 400 \\
\hline Metais ( $\mathrm{mL} \mathrm{L}^{-1}$ ) & 0,375 & 0,09375 & 0,1875 & 0,375 & 0,75 & 0,75 \\
\hline Sais $\left(\mathrm{mL} \mathrm{L}^{-1}\right)$ & 0,75 & 0,1875 & 0,375 & 0,75 & 1,5 & 1,5 \\
\hline Nutrientes $\left(\mathrm{mL} \mathrm{L}^{-1}\right)$ & 1,125 & 0,28125 & 0,5625 & 1,125 & 2,25 & 2,25 \\
\hline Complementação $\left(\mathrm{mL} \mathrm{L}^{-1}\right)$ & 1,0 & 1,0 & 1,0 & 1,0 & 1,0 & 1,0 \\
\hline Vitaminas $\left(\mathrm{mL} \mathrm{L}^{-1}\right)$ & 1,0 & 1,0 & 1,0 & 1,0 & 1,0 & 1,0 \\
\hline Bicarbonato de sódio $\left(\mathrm{mg} \mathrm{L}^{-1}\right)$ & 1,5 & 0,375 & 0,75 & 1,5 & 3 & 3 \\
\hline
\end{tabular}

\subsection{Metodologia analítica}

O monitoramento da fase líquida baseou-se em determinação regular dos seguintes parâmetros: DQO, $\mathrm{pH}, \mathrm{SO}_{4}{ }^{2-}$, sulfeto total dissolvido (STD), sólidos totais dissolvidos (SSV) alcalinidade parcial (AP), e ácidos voláteis totais (AVT). DQO, $\mathrm{pH}, \mathrm{SO}_{4}{ }^{2-} \mathrm{STD}$ e SSV foram mensurados de acordo com procedimentos descritos no Standard Methods for the 
Examination of Water and Wastewater (APHA/AWWA/WEF, 2005). O valor de pKa $(6,6)$ para o primeiro estágio de ionização do sulfeto $\left(\mathrm{H}_{2} \mathrm{~S}_{(\mathrm{aq})} \leftrightarrow \mathrm{HS}^{-}\right)$sob a temperatura de operação ( $\mathrm{T}$ de $55^{\circ} \mathrm{C}$ ), calculado de acordo com a Equação 1, enquanto a distribuição da especiação do sulfeto, isto é, $\left[\mathrm{H}_{2} \mathrm{~S}_{\text {](aq) }}\right.$ e $\left[\mathrm{HS}^{-}\right]$determinada conforme a Equação 2 (Callado, Damianovic, \& Foresti, 2015).

$$
\begin{array}{ll}
\mathbf{p K a}=7.257 \cdot \exp (-0.00172 \cdot \mathrm{T}) & \text { Equação } 1 \\
\mathbf{p H}=\mathbf{p K a}+\log \frac{\left[\mathrm{HS}^{-}\right]}{\left[\mathrm{H}_{2} \mathrm{~S}\right]_{(\mathrm{qq})}} & \text { Equação } 2
\end{array}
$$

AP e AVTs foram mensurados usando método titulométrico, descrito por Ripley, Boyle, \& Converse (1986) e DiLallo \& Albertson (1961) respectivamente. A composição dos AVT foi determinada em cromatógrafo gasoso modelo GC 2010 (Shimadzu Scientific Instruments, Kyoto, Japão), equipado com detector de ionização de chama (FID) e coluna HPINNOWAX $(30 \mathrm{~m} \times 0,25 \mathrm{~mm} \times 0,25 \mu \mathrm{m})$, de acordo com Adorno, Hirasawa, \& Varesche (2014).

As principais variáveis-resposta usadas para avaliar o desempenho do sistema foram as cargas orgânica volumétrica removida (COVrem; $\mathrm{kg}$ DQO $\mathrm{m}^{-3} \mathrm{dia}^{-1}$,) e sulfato (CSVrem, $\left.\mathrm{kg} \mathrm{SO}_{4}{ }^{2-} \mathrm{m}^{-3} \mathrm{dia}^{-1}\right)$ e eficiências de remoção de DQO (ER $\left.\mathrm{DQO} ; \%\right)$, etanol (ER $\left.\mathrm{EtOH} ; \%\right)$ e $\mathrm{SO}_{4}{ }^{2-}$ $\left(\mathrm{ER}_{\mathrm{SO} 4} ; \%\right)$.

O monitoramento da fase gasosa baseou-se na medição da composição do biogás. A composição do biogás $\left(\mathrm{CH}_{4}, \mathrm{CO}_{2}, \mathrm{~N}_{2}\right.$ e $\left.\mathrm{H}_{2} \mathrm{~S}\right)$ foi regularmente determinada por cromatógrafo gasoso com detector de condutividade térmica, modelo GC-2014 (Shimadzu Scientific Instrument), equipado com coluna HP-PLOT/Q $(30 \mathrm{~m} \times 0,54 \mathrm{~mm} \times 40 \mu \mathrm{m})$ usando hidrogênio como gás de arraste (Lebrero, Toledo-Cervantes, Muñoz, del Nery, \& Foresti, 2016). Esporadicamente amostras do biogás foram analisadas por GC/TCD (modelo GC2010, Shimadzu Scientific Instruments, Columbia, MD, USA) usando argônio como gás de arraste (Perna et al., 2013) para avaliar a presença de hidrogênio. 


\section{RESULTADOS E DISCUSSÃO}

Nessa seção serão abordados os resultados obtidos na operação dos reatores acidogênicos/sulfetogênico e os metanogênico. A discussão está divida em itens de acordo com cada reator: reator acidogênico/sulfetogênico com polietileno (PEBD) como material suporte $\left(\mathrm{R}_{\mathrm{AS}-\mathrm{PEBD}}\right)$, reator acidogênico/sulfetogênico com espuma de poliuretano (PU) como material suporte $\left(\mathrm{R}_{\mathrm{AS}-\mathrm{PU}}\right)$, reatores metanogênico de segunda fase e fase única. Ao final da apresentação dos resultados dos reatores acidogênicos/sulfetogênico, há breves considerações finais quanto ao desempenho de $\mathrm{R}_{\mathrm{AS}-\mathrm{PEBD}}$ e $\mathrm{R}_{\mathrm{AS} \text {-PU. Já os reatores metanogênicos possuem }}$ uma discussão única com comparação entre o desempenho de sistema com separação de fase e fase única.

\subsection{Reator acidogênicos/sulfetogênico com polietileno (PEBD) como material suporte ( $\left.\mathbf{R}_{\text {AS-PEBD }}\right)$}

O reator acidogênico/sulfetogênico de polietileno foi operado e monitorado por 631 dias, baseando-se em parâmetros associados à redução do sulfato.

A discussão dos resultados encontra-se dividida em cinco principais etapas operacionais: i) etapa de adaptação da biomassa, ii) efeito da recirculação sobre a sulfetogênese, iii) restabelecimento do processo, já que este sofre com alteração nas condições estabelecidas em fase anterior; iv) determinação de condição operacional de forma que resultasse em um efluente com reduzida concentração de sulfato, para sequencial aplicação em reator metanogênico; v) efeito da redução da carga orgânica volumétrica sobre a redução do sulfato e o biogás.

Ao final da seção de discussão dos resultados do reator acidogênico/sulfetogênico com PEBD como material suporte, há uma síntese dos resultados obtidos ao longo de toda a operação (FIGURA 15, Tabela 11).

\subsubsection{ETAPA 1: ADAPTAÇÃO DA BIOMASSA PARA UM SISTEMA SULFETOGÊNICO}

O estabelecimento de uma condição para redução biológica do sulfato a sulfeto em reator acidogênico/sulfetogênico e termofílico foi avaliada com a adoção de diferentes estratégias operacionais, tais como a variação da relação $\mathrm{DQO} / \mathrm{SO}_{4}{ }^{2-}$ pela variação da carga de sulfato volumétrica, TDH e sistema de recirculação. O TDH inicialmente selecionado baseouse em condições operacionais de reatores acidogênicos, que normalmente requerem reduzido tempo de detenção hidráulica (Hallenbeck \& Ghosh, 2009; Show, Lee, Tay, Lin, \& Chang, 
2012), aplicando-se o TDH de 6 horas para o $\mathrm{R}_{\mathrm{AS}-\mathrm{PEBD}}$ nas subetapas I-III. A elevada carga orgânica volumétrica (até a subetapa XI) objetivou a inibição da produção de metano por arqueias metanogênicas.

A avaliação do sistema tomou como parâmetro principal a remoção da carga de sulfato em cada uma das etapas. As estratégias operacionais adotadas ao longo da operação visaram otimizar a remoção de sulfato do meio líquido.

Para as três primeiras subetapas da etapa $1\left(\mathrm{R}_{\mathrm{AS}-\mathrm{PEBD}}-\mathrm{I}\right.$, II e III), o TDH esteve fixado em 6 horas e a carga de sulfato afluente variada de 8 à $16 \mathrm{~kg}-\mathrm{SO}_{4}{ }^{2-} \mathrm{m}^{-3} \mathrm{~d}^{-1}$ (Tabela 2). Devido à baixa carga de sulfato removida na subetapa $\mathrm{I}$, optou-se em reduzir a relação $\mathrm{DQO} / \mathrm{SO}_{4}{ }^{2-} \mathrm{de}$ 2,5 para 1,66 na subetapa II e posteriormente para 1,25 (subetapa III).

Verificou-se que a o aumento da CSV proporcionou um aumento na carga de sulfato removida nas subetapas I, II e III (FIGURA 8-b) favoreceu a sulfetogênes, respectivamente

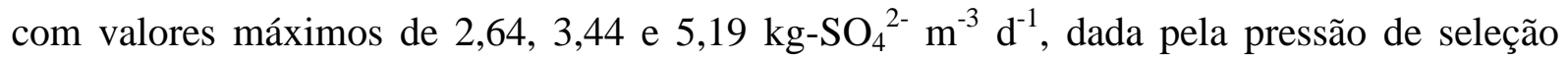
imposta pela redução da relação $\mathrm{DQO} / \mathrm{SO}_{4}{ }^{2-}$. No entanto, a eficiência média de remoção de sulfato manteve-se a mesma (Tabela 11) à medida que a concentração de $\mathrm{SO}_{4}{ }^{2-}$ no afluente foi aumentada $\left(\mathrm{R}_{\mathrm{AS}-\mathrm{PEBD}}\right.$ subetapa $\mathrm{I}=27,5 \%$ e subetapa $\mathrm{III}=26 \%$ ), o que sugeriu uma limitação da atividade sulfetogênica, já que permaneceu limitada em uma faixa de remoção, não alcançando valores de eficiência desejáveis. O aumento do TDH para 12 horas favoreceu maior estabilidade ao sistema, visto a menor dispersão dos dados (FIGURA 8-b), porém a remoção encontrou-se abaixo de 50\%. O aumento na eficiência de $\operatorname{CSV}_{\text {rem }}$ de $26 \%$ (fase III) para $41,2 \%$ (fase IV) resultou da baixa $\mathrm{CSV}_{\mathrm{afl}}\left(5,1 \mathrm{~kg} \mathrm{SO}_{4}{ }^{2-} \mathrm{m}^{-3} \mathrm{dia}^{-1}\right)$ comparado ao valor teórico $\left(8 \mathrm{~kg} \mathrm{SO}_{4}{ }^{2-} \mathrm{m}^{-3} \mathrm{dia}^{-1}\right)$, devido a problemas na bomba de alimentação, de modo que não represente uma efetiva melhora da atividade sulfetogênica (CSVrem 4,03 $\mathrm{kg} \mathrm{SO}_{4}{ }^{2-} \mathrm{m}^{-3} \mathrm{dia}^{-1} \mathrm{na}$ fase III e 2,04 $\mathrm{kg} \mathrm{SO}_{4}{ }^{2-} \mathrm{m}^{-3} \mathrm{dia}^{-1}$ na fase IV; FIGURA 8-b, Tabela 11) Os valores de $\mathrm{pH}$ permaneceram dentro de um intervalo adequado (6,13-6,37 - Tabela 11) para atuação das BRS, de modo que os efeitos negativos não devem ser associados a este parâmetro nessas fases iniciais. Relatos apontam que a inibição das BRS ocorre em pH inferiores a 5,5-5,8 (Hwang, Cha, et al., 2009; Hwang, Choi, Abou-Shanab, Bhatnagar, Min, Song, Kumar, Choi, Lee, \& Kim, 2009; Lin \& Chen, 2006).

O padrão observado na remoção de $\mathrm{SO}_{4}{ }^{2-}$ durante as fases I-IV resultou principalmente da aplicação de um TDH relativamente baixo ( $6 \mathrm{~h}$, fases I-III), o que provavelmente impediu o estabelecimento das BRS. Polo et al. (2006) reportaram a baixa atividade sulfetogênica em 
reator do tipo empacotado e utilizando lactato como fonte de carbono em TDH abaixo de 10 horas, sugerindo tempo ideal entre 20-30 horas. Reis et al. (1991) também indicaram redução acentuada na remoção de $\mathrm{SO}_{4}{ }^{2-}\left(3,3\right.$ para $\left.1,0 \mathrm{~kg}-\mathrm{SO}_{4}{ }^{2-} \mathrm{m}^{-3} \mathrm{~d}^{-1}\right)$ à medida que a taxa de diluição foi aumentada de $0,035 \mathrm{~h}^{-1}(\mathrm{TDH}=28,6 \mathrm{~h})$ para $0,167 \mathrm{~h}^{-1}(\mathrm{TDH}=6 \mathrm{~h})$ em CSTR alimentado com vinhaça de cana de açúcar e operado em condições acidogênicas a pH =6,2. Portanto, o baixo TDH aplicado durante as fases I-III $(6 \mathrm{~h})$ provavelmente favoreceu a lavagem da população de BRS (SSV = 175-212 $\mathrm{mg} \mathrm{L}^{-1}$ ), o que pode explicar o desempenho insatisfatório.

Os efeitos tóxicos associados à produção de sulfeto também podem afetar a atividade das BRS, observando o crescente aumento das concentrações neste período (170-248 mg L ${ }^{-1}$ de STD e 93-156 $\mathrm{mg} \mathrm{L}^{-1}$ como $\mathrm{H}_{2} \mathrm{~S}(\mathrm{aq})$; FIGURA 8 e Tabela 11), devido a aplicação de baixa relação DQO/ $\mathrm{SO}_{4}{ }^{2}$, ou seja, maiores concentrações de sulfato. De acordo com Parkin et al. (1990), esses valores são capazes de provocar inibição das metanogênicas no sistema (100$800 \mathrm{mg} \mathrm{L}^{-1}$ de STD e 50-200 $\mathrm{mg} \mathrm{L}^{-1} \mathrm{H}_{2} \mathrm{~S}_{(\mathrm{aq})}$ ), de modo que os efeitos negativos provavelmente foram agravados pela lavagem da biomassa do reator.

A elevada temperatura de operação também caracteriza um fator negativo na estabilização das condições para redução do sulfato, diretamente relacionada ao crescimento celular, o que provoca condições de stress e aumento na taxa de decaimento celular (Amani, Nosrati, Mousavi, \& Elyasi, 2015). Comparativamente, o tempo de duplicação superior a $9 \mathrm{~h}$ deve ser esperado para BRS submetidas às condições de operação termofílica, utilizando valor obtido por Reis et al. (1988) sob condições mesofílicas $\left(35^{\circ} \mathrm{C}\right)$ e ácidas $(\mathrm{pH}=6,6)$ como referência. O uso de etanol como doador de elétrons também pode ter limitado o estabelecimento imediato de um ambiente eficiente na redução de sulfato, uma vez que o rendimento de energia mais baixos (Reação 1) geralmente são obtidos a partir da oxidação do etanol por BRS em comparação com outras fontes de carbono ( por exemplo, lactato e propionato (Reações 7 e 11) (Cao et al., 2012; Nagpal, Chuichulcherm, Livingston, \& Peeva, 2000). Em síntese, embora havendo área superficial para fixação da biomassa, uma combinação de condições de operação desfavoráveis provavelmente impediu o estabelecimento de uma efetiva atividade de redução do sulfato no reator durante as fases IIII, o qual se comportou principalmente como um sistema acidogênico, baseado em dados específicos de desempenho: baixa $\mathrm{ER}_{\mathrm{DQO}}(<22,5 \%$; Tabela 11$)$ e aumento da concentração de

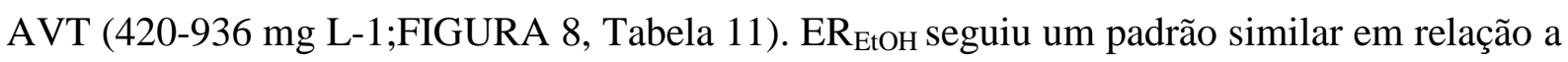
$\mathrm{ER}_{\mathrm{SO} 4}$ nas fases operacionais iniciais $(19,0-20,5 \%$; fases I-II; Tabela 11) o que confirma que a atividade das BRS foi dificultada. 
FIGURA 8 - Resultados operacionais referentes à etapa 1 do reator acidogênico/sulfetogênico com PEBD como material suporte PEBD (a) Carga orgânica volumétrica removida; (b) Carga de sulfato volumétrica removida; (c) Sulfeto; (d) AVT.
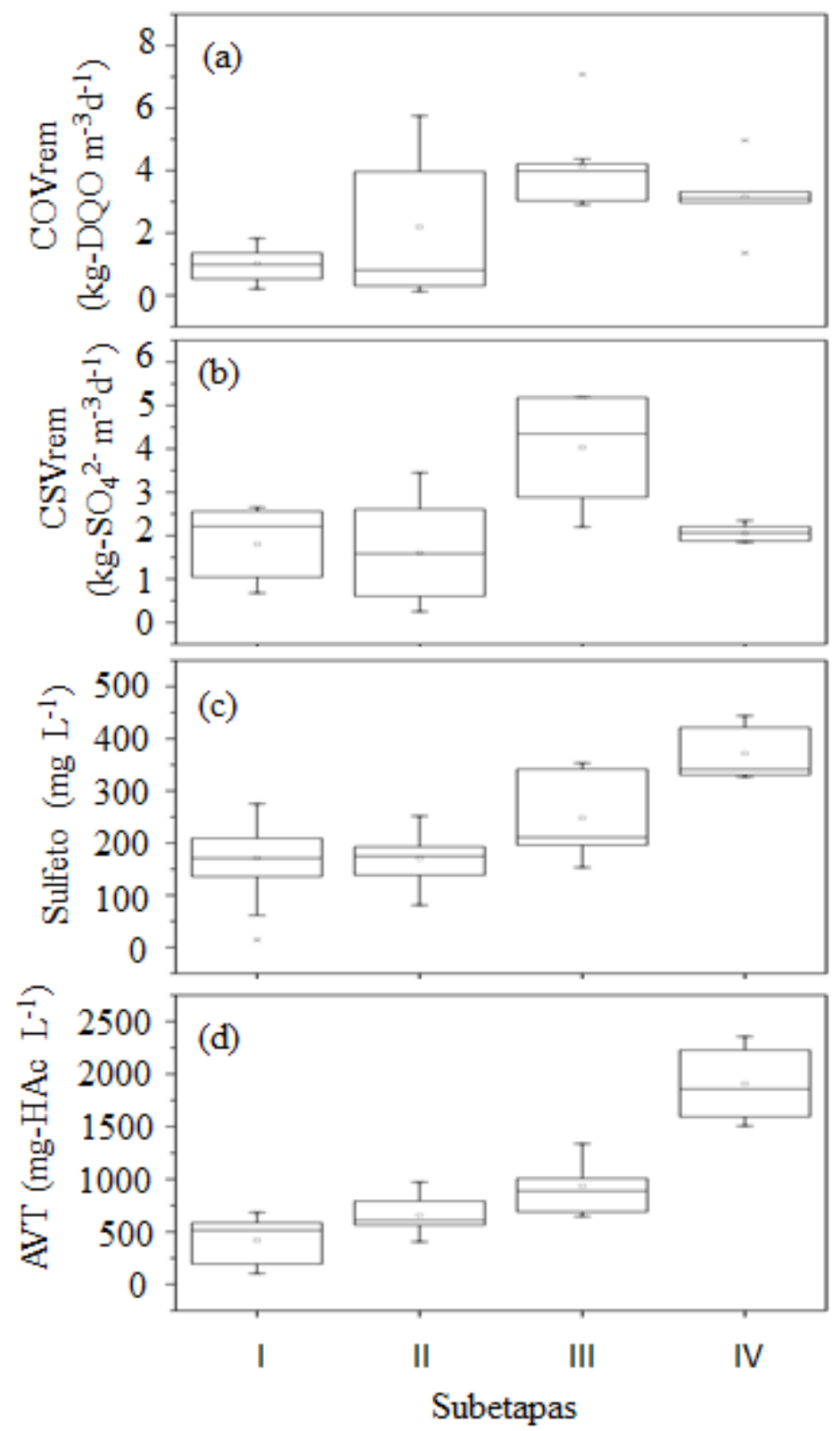

As características do lodo termofílico aplicado na etapa de inoculação também deve ser considerado quando o desempenho é avaliado. Embora análises de biologia molecular tenham identificado microrganismos redutores de sulfato, tais como Thermodesulfovibrio, Desulfitibacter, Desulfomicrobium, Desulfovibrio, Desulfomonas, Desulfobulbus ,entre outros, observou-se uma abundância relativa menor que 1\% (Fuess, Kiyuna, et al., 2017). Essa característica particular é devida a elevada relação $\mathrm{DQO} / \mathrm{SO}_{4}{ }^{2-}$, normalmente observada em vinhaça de cana-de-açúcar durante a maior parte do período de colheita, apresentando 
proporções acima de 10 (Fuess, Araújo Jr., Garcia, \& Zaiat, 2017; Fuess, Garcia, \& Zaiat, 2017), o que tende a minimizar o fluxo de elétrons (<10\%) da metanogênese para sulfetogênese em plantas anaeróbias (Kiyuna, Fuess, \& Zaiat, 2017). Portanto, a reduzida abundância relativa de BRS no inóculo pode ter acentuado as limitações para o estabelecimento da sulfetogênese, mesmo quando TDH passou para 12h (fase IV).

Com o incremento da sulfetogênese na subetapa IV, observou-se aumento da concentração de sulfeto ( $\mathrm{STD}=372 \mathrm{mg} \mathrm{L}^{-1} \mathrm{e} \mathrm{H}_{2} \mathrm{~S}_{(\mathrm{aq})}=260$, FIGURA 8-c e Tabela 11) e AVT (1907 mg L $\mathrm{L}^{-1}$ FIGURA 8-d e Tabela 11) colaborando negativamente na atividade sulfetogênica, associado ao aumento da concentração de sólidos no efluente do reator que foi, em média de $305 \mathrm{mg}-\mathrm{SSV} \mathrm{L}^{-1}$ ). Para a etapa 1 , adotou-se velocidade ascensional semelhantes, com 1,22 $\mathrm{m} \mathrm{h}^{-1}$ nas subetapas I-III e $1,16 \mathrm{~m} \mathrm{~h}^{-1}$ na subetapa IV, o que não foi capaz de promover o deslocamento do sulfeto para fase gasosa, como confirmado pelo acumulado na fase líquida (95\%, FIGURA 15). A análise cromatográfica confirmou a produção de ácido acético como único AVT (resultado da atuação das BRS oxidadoras incompletas), o que pode ter exercido efeito inibitório sobre a comunidade microbiana, inclusive as BRS. Porém, estudos anteriores (Reis et al., 1988, 1991) reportaram sucesso na remoção de $\mathrm{SO}_{4}{ }^{2-}\left(\mathrm{ER}_{\mathrm{SO} 4}>\right.$ $80 \%)$ em sistemas acidogênicos submetidos a elevadas concentrações de ácido acético $(4,4-$ 7,5 $\left.\mathrm{g} \mathrm{L}^{-1}-35^{\circ} \mathrm{C}\right)$ superiores ao observado na subetapa IV (1.907 $\left.\mathrm{mg} \mathrm{L}^{-1}\right)$, TDH de 22 horas e valores de $\mathrm{pH}$ similares $(6,2-6,4)$. A elevada temperatura torna a membrana celular mais permeável (Infantes, González Del Campo, Villaseñor, \& Fernández, 2011), o que facilita a entrada de ácidos não dissociados para o interior da célula. Esse fato explica os efeitos potencialmente inibitórios causados por baixa concentração de AVT comparado aos valores reportados em sistemas mesofílico.

Em particular, os baixos TDHs utilizados neste estudo (6-12h), associados à condição termofílica $\left(55^{\circ} \mathrm{C}\right)$ podem ter influenciado negativamente na atividade das BRS no período operacional inicial. Os efeitos negativos poderiam ser minimizados com adoção de condições operacionais favoráveis para adaptação da biomassa às condições propícias para o estabelecimento da sulfetogênese, o que motivou a aplicação de estratégias adicionais.

\subsubsection{ETAPA 2: RECIRCULAÇÃO DA FASE LÍQUIDA}

A re-inoculação do sistema, na subetapa $\mathrm{V}$, teve como objetivo compensar a biomassa perdida ao longo etapa 1 (subetapas I-IV), de forma que além de repor a biomassa termofílica, também houve o enriquecimento devido à mistura com lodo mesofílico rico em BRS. A 
estratégia foi motivada por trabalhos que reportaram o sucesso na estabilização de condições para redução de sulfato, indicando remoção acima de $85 \%$ sob diversas condições operacionais: $\mathrm{DQO} / \mathrm{SO}_{4}{ }^{2-}$ de $3,0\left(\mathrm{SO}_{4}{ }^{2-}=1.300 \mathrm{mg} \mathrm{L}^{-1}, 25^{\circ} \mathrm{C}\right.$; Godoi et al., 2015), 3,0 $\left(\mathrm{SO}_{4}{ }^{2-}=\right.$ $1.300 \mathrm{mg} \mathrm{L}{ }^{-1}, 30^{\circ} \mathrm{C}$; Damianovic, Saia, de Godoi, \& Foresti, 2016), $1,7\left(\mathrm{SO}_{4}{ }^{2-}=200 \mathrm{mg} \mathrm{L}^{-1}\right.$; Rodriguez et al., 2012) e $1,0\left(\mathrm{SO}_{4}{ }^{2-}=1.000 \mathrm{mg} \mathrm{L}^{-1}, 30^{\circ} \mathrm{C}\right.$; Camiloti et al., 2014), 28,3 $\left(\mathrm{SO}_{4}{ }^{2-}=\right.$ $1.800 \mathrm{mg} \mathrm{L}^{-1}, 55^{\circ} \mathrm{C}$; Ribas et al., 2009).

Outra estratégia para incrementar a redução de sulfato foi o aumento da razão de recirculação de 19 para 38 (subetapas IV-V; Tabela 11), respectivamente com velocidades ascensionais de 2,25 e $3,35 \mathrm{~m} \mathrm{~h}^{-1}$, tendo como objetivo reduzir os efeitos adversos do sulfeto sobre a biomassa sulfetogênica promovido pela diluição e stripping para fase gasosa, associado à reinoculação.

A aplicação dessas estratégias conjuntas impactou positivamente na atividade sulfetogênica (subetapa V: CSVrem $=4,1 \mathrm{~kg} \mathrm{~m}^{-3} \mathrm{~d}^{-1}$. ER $\mathrm{SO}_{\mathrm{SO}}=48.7 \%$; fase VI: CSVrem $=5,3$ $\mathrm{kg} \mathrm{m}^{-3} \mathrm{~d}^{-1}$. ER $\mathrm{SO}_{\mathrm{S}}=57,3 \%$; FIGURA 9-b, Tabela 11), permitindo o estabelecimento da redução do sulfato em condições acidogênicas.

O aumento na eficiência de conversão do etanol atingiu aproximadamente $60 \%$ na subetapa VI; Tabela 11), em que se aplicou a maior velocidade ascensional $\left(3,35 \mathrm{~m} \mathrm{~h}^{-1}\right)$. As concentrações de sulfeto no líquido foram similares nas subetapas V (STD $=319 \mathrm{mg} \mathrm{L}^{-1}$; $\left.\mathrm{H}_{2} \mathrm{~S}(\mathrm{aq})=232 \mathrm{mg} \mathrm{L}^{-1}\right)$ e VI $\left(\mathrm{STD}=307 \mathrm{mg} \mathrm{L}^{-1} ; \mathrm{H}_{2} \mathrm{~S}(\mathrm{aq})=207 \mathrm{mg} \mathrm{L}^{-1}\right)$, embora a conversão de sulfato tenha sido superior na subetapa VI. O aumento da velocidade ascensional foi responsável pela manutenção da concentração de sulfeto no meio líquido, não provocando efeito inibitório. Portanto, dois padrões distintos regeram a toxicidade ao sulfeto nas subtapas IV, V e VI: a desvantagem quanto ao estabelecimento de uma população redutora de sulfato sob condições de baixo TDH em suas fases iniciais, o que pode ter acentuado os efeitos tóxicos da elevada concentração de $\mathrm{STD}$ e $\mathrm{H}_{2} \mathrm{~S}_{(\mathrm{aq})}$ sobre uma biomassa instável. Por sua vez, a etapa de reinoculação enriqueceu a população redutora de sulfato tornando o reator robusto e capaz de suportar elevada concentração de sulfeto e AVT (subetapa VI= $3.111 \mathrm{mg} \mathrm{L}^{-1}$, FIGURA 9-d), superando os desafios comuns de sistemas termofílico, como o aumento na taxa decaimento celular (Amani et al., 2015) e elevada permeabilidade celular (Infantes et al., 2011). Baseada na atividade sulfetogênica observada, o aumento na perda de SSV na subetapa VI (180 mg-SSV L $\left.{ }^{-1}\right)$, comparada a subetapa V (95 mg-SSV $\left.\mathrm{L}^{-1}\right)$ durante a etapa 2, não causou redução na eficiência de redução do sulfato. 
Considerando as cargas de sulfato medidas e assumindo que $1 \mathrm{~g}$ de $\mathrm{SO}_{4}{ }^{2-}$ reduzido produz $0,33 \mathrm{~g}$ de sulfeto total, as concentrações teóricas de sulfeto para as subetapas V e VI (FIGURA 9) deveriam atingir 717 e $832 \mathrm{mg} \mathrm{L}^{-1}$ respectivamente. No entanto, o aumento da recirculação aplicada a estas fases permitiu o deslocamento de 56\% (subetap V) e 63\% (subetapa VI) do $\mathrm{H}_{2} \mathrm{~S}$ gerado na fase líquida para a fase gasosa, reduzindo os potenciais efeitos inibitórios sobre a biomassa. Esses valores são muito superiores aos estimados para as fases iniciais (5-25\%, subetapas I-IV; FIGURA 15), confirmando a eficiência da recirculação na minimização da carga de sulfeto em sistemas anaeróbios, com o deslocamento para a fase gasosa, de acordo com dados obtidos referente ao biogás (discutido no item 5.1.7 Biogás). No entanto, a adoção desse tipo de estratégia requer atenção para uma aplicação ou destino adequados do biogás rico em $\mathrm{H}_{2} \mathrm{~S}$ (Muñoz, Meier, Diaz, \& Jeison, 2015).

O aumento da concentração de AVT nas subetapas V (2.629 mg L ${ }^{-1}$; FIGURA 9-d e

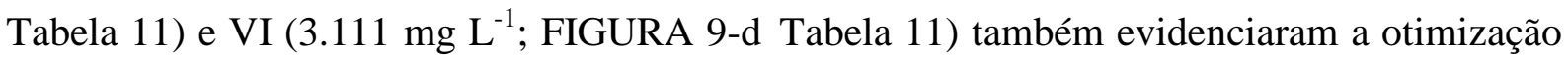
do sistema após o aumento na taxa de recirculação. A baixa eficiência de remoção da matéria orgânica sugere BRS oxidadoras incompletas predominaram a rota metabólica de redução do sulfato. Deste modo, as metanogênicas foram suprimidas pela estratégia operacional, destacando principalmente o $\mathrm{pH}$ de operação, cuja faixa ótima para o metabolismo metanogênico está entre 6,8 e 7,5 e menor tolerância ao sulfeto, o que caracterizou no acúmulo de ácido acético no efluente do reator, sendo este um substrato valioso para aplicação em reator metanogênico de segundo estágio.

Lopes, Wang, Capela, \& Lens (2007) e Reis et al. (1991 e 1988) avaliaram a estabilização da redução de sulfato sob condições acidogênicas aplicada a diferentes configurações de reatores (CSTR, leito fixo, UASB) e estratégias operacionais (variação do pH afluente, tipo de substrato, temperatura). Embora o ácido acético tenha sido determinado em todos os casos, proporções de ácido propiônico e butírico foram detectados no sistema, indicando que as BRS não poderiam metabolizar plenamente todos os substratos, devido à diversidade da matriz efluente, proveniente de águas residuária como vinhaça ou sacarose, favorecendo várias rotas metabólicas trabalhando paralelamente, tais como as bactérias fermentativas. Por outro lado, o etanol é convertido diretamente a ácido acético pelas BRS oxidadoras incompletas (Tabela 1-a), o que confirma o efetivo estabelecimento da população sulfetogênica após a re-inoculação do sistema. A maior robustez do sistema provavelmente reduziu à sensibilidade da biomassa às elevadas concentrações de AVT, similar ao observado para o sulfeto. 
FIGURA 9 - Resultados operacionais referentes à etapa 2 do reator acidogênico/sulfetogênico com PEBD como material suporte PEBD (a) Carga orgânica volumétrica removida; (b) Carga de sulfato volumétrica removida; (c) Sulfeto; (d) AVT.
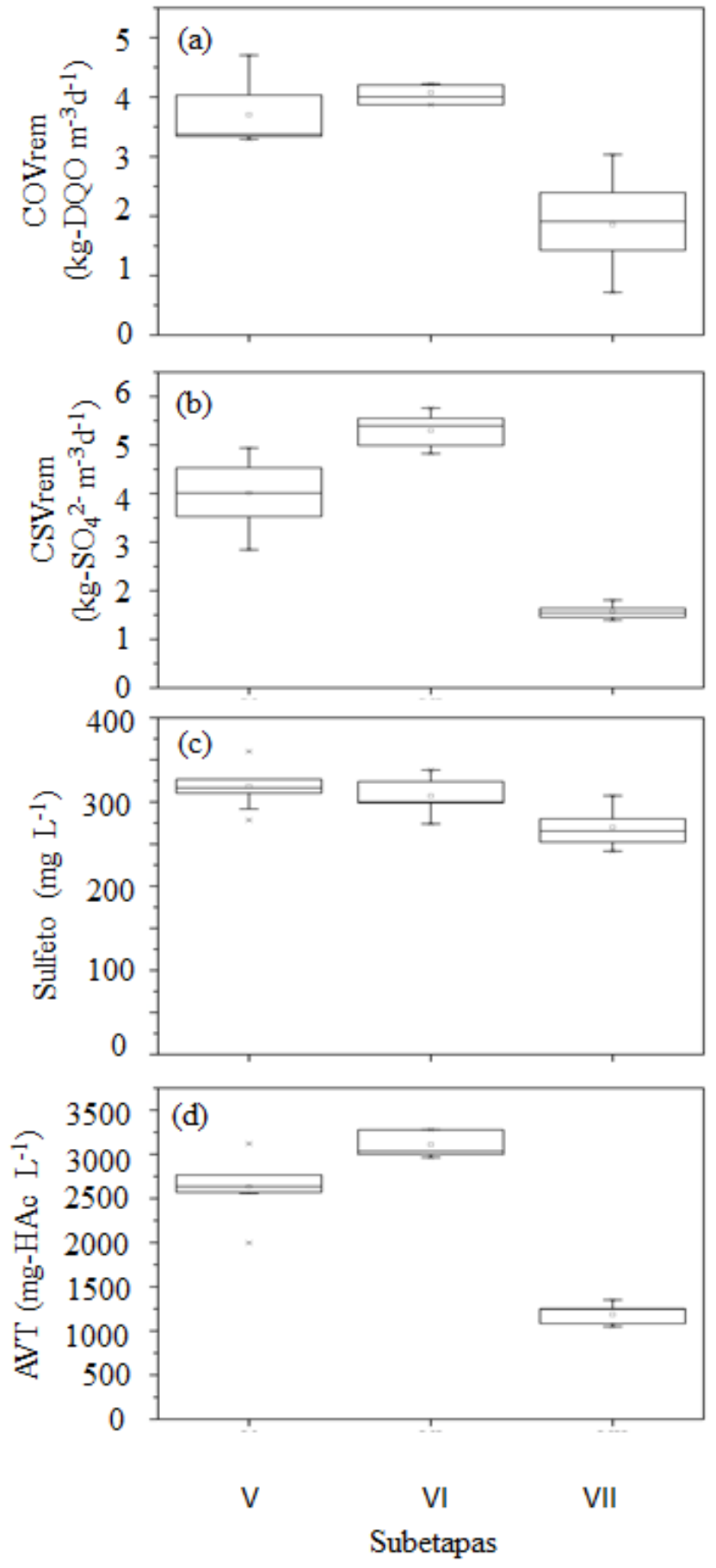

A retirada da recirculação do meio líquido na subetapa VII impactou negativamente na atividade sulfetogênica do reator, ocasionando queda na CSVrem $\left(1,6 \mathrm{~kg} \mathrm{SO}_{4}{ }^{2-} \mathrm{m}^{-3} \mathrm{dia}^{-1}\right.$, FIGURA 9-b) comparado com as etapas anteriores $\left(4,0 \mathrm{~kg} \mathrm{SO}_{4}{ }^{2-} \mathrm{m}^{-3} \mathrm{dia}^{-1}\right.$, subetapa $\mathrm{V}$ e 5,3 $\mathrm{kg} \mathrm{SO}_{4}{ }^{2-} \mathrm{m}^{-3} \mathrm{dia}^{-1}$, subetapa VI; FIGURA 10 -b). Os padrões decrescentes foram observados em $\operatorname{ER}_{\mathrm{SO} 4}\left(25,3 \%\right.$, Tabela 11), $\operatorname{ER}_{\mathrm{EtOH}}(22,3 \%$, Tabela 11$)$ e produção de AVT (1.187 mg L $\mathrm{m}^{-1}$; 
FIGURA 9-d, Tabela 11) em comparação com as subetapas V e VII. A redução dos níveis de produção de AVT confirma o papel determinante das BRS na produção de acetato. Por outro lado, as concentrações de $\operatorname{STD}\left(270 \mathrm{mg} \mathrm{L}^{-1}\right)$ e $\mathrm{H}_{2} \mathrm{~S}_{(\mathrm{aq})}\left(208 \mathrm{mg} \mathrm{L}^{-1}\right)$ permaneceram semelhantes às fases anteriores (IV-VI, Tabela 11). Apesar das perdas de desempenho observadas na redução do sulfato, aproximadamente $90 \%$ do sulfeto total produzido permaneceu na fase líquida, o que explica valores similares de STD e $\mathrm{H}_{2} \mathrm{~S}_{(\text {aq) }}$ comparado aos observados na aplicação da recirculação. Particularmente este resultado indicou que a toxicidade ao sulfeto não foi o principal fator que afetou o desempenho do sistema na fase VII, embora o gradiente de formação do $\mathrm{H}_{2} \mathrm{~S}$ tenha impactado negativamente às BRS na região mais baixa do leito reacional. A lavagem da biomassa foi marcada por menores concentrações de SSV no efluente $\left(\mathrm{SSV}=95 \mathrm{mg} \mathrm{L}^{-1}\right.$, subetapa $\mathrm{V}, \mathrm{SSV}=180 \mathrm{mg} \mathrm{L}^{-1}$, subetapa VI e SSV = $37 \mathrm{mg} \mathrm{L}^{-1}$, subetapa VII). Uma hipótese para explicar a perda de eficiência na subetapa VII refere-se ao baixo $\mathrm{pH}$ mantido no interior do reator o que impacta negativamente no metabolismo das BRS (Hwang, Cha, et al., 2009; Hwang, Choi, AbouShanab, Bhatnagar, Min, Song, Kumar, Choi, Lee, Kim, et al., 2009; Reis et al., 1988, 1991).

A aplicação da recirculação foi um fator determinante para manter $\mathrm{pH}$ adequado ao longo da altura do reator devido à re-introdução da alcalinidade produzida na redução do sulfato pelas BRS (Bertolino, Rodrigues, Guerra-Sá, Aquino, \& Leão, 2012), quando os elevados níveis de AVT produzidos foram observados (subetapas V e VI, FIGURA 9-d, Tabela 11). A formação de alcalinidade provavelmente decorrente da oxidação completa do etanol pelas BRS, cujos íons bicarbonato são prontamente liberados ao meio líquido (Reação 2; Zhou \& Xing, 2015). Os valores relativamente elevados de alcalinidade parcial nas subetapas V e VI (189-206 mg L ${ }^{-1}$; Tabela10) seguido por acentuado decréscimo durante a subetapa VII (90 $\mathrm{mg} \mathrm{L}^{-1}$; Tabela 10), colabora com esta hipótese, indicando um efeito positivo adicional da recirculação do efluente em reator acidogênico/sulfetogênico, promovendo adequado controle da capacidade tampão do sistema. No entanto, não foram observadas diferenças acentuadas do pH ao longo desse período de operação(6,06-6,37, subetapas I-VII; Tabela 11), mesmo quando não houve aplicação da recirculação, de modo que foram utilizadas estratégias complementares para identificar os impactos do $\mathrm{pH}$ na atividade sulfetogênica, com base na formação potencial de um gradiente de $\mathrm{pH}$ ao longo da altura do reator. 


\subsubsection{Caracterização espacial do $R_{A S-P E B D}$}

Perfis espaciais foram obtidos para avaliar o comportamento da produção de sulfeto e valores de $\mathrm{pH}$ ao longo da altura do reator (do fundo para o topo) nas fases V-VII, na formação de $\mathrm{H}_{2} \mathrm{~S}$ e gradiente de $\mathrm{pH}$ em diferentes porções do reator. $\mathrm{O}$ monitoramento teve como pontos amostrados A, C e E (região reacional; FIGURA 3) e a saída de efluente do reator. A especiação do sulfeto para cada ponto amostrado foi determinada de acordo com as Equações 1 e 2 . O perfil longitudinal obtido nas subetapas selecionadas estão apresentados FIGURA 10a-c. A aplicação da recirculação promoveu reduzida variação no $\mathrm{pH}$ ao longo do reator nas subetapas V e VI, com valores sempre acima de 6,1 (subetapa V) e 6,2 (subetapa VI) (FIGURA a-c). O comportamento confirma o papel determinante da reinserção da alcalinidade produzida a partir do metabolismo das BRS, o que permitiu uma alta atividade sulfetogênica ao longo de toda altura do reator FIGURA a-b). Especialmente os perfis obtidos para as subetapas V FIGURA 10-a) e VI (FIGURA 10-b) indica concentração relativamente elevada de $\mathrm{H}_{2} \mathrm{~S}_{(\mathrm{aq})}$ (acima de $250 \mathrm{mg} \mathrm{L}^{-1}$ ) ao longo de todo o reator, confirmando o sulfeto não causou impacto negativo para essas fases operacionais.

O perfil espacial obtido na subetapa VII (FIGURA 10-c, sem recirculação do efluente) indica a formação de um gradiente de $\mathrm{pH}$ ao longo do reator, mostrando redução imediata do $\mathrm{pH}$ na zona de mistura (5,67, amostrador A). Este comportamento compreende uma característica comum em sistemas acidogênicos (Anzola-Rojas et al., 2016), com base na atividade das bactérias fermentativas devida a maiores densidades celulares na porção inferior do leito. Damianovic et al. (2016) verificaram que a redução do sulfato em reator horizontal ocorreu principalmente na primeira secção do reator. Estudos reportam uma baixa atividade sulfetogênica em valores de pH inferiores a 5,8 (Hwang, Cha, et al., 2009; Hwang, Choi, Abou-Shanab, Bhatnagar, Min, Song, Kumar, Choi, Lee, Kim, et al., 2009; Lin \& Chen, 2006; Reis et al., 1988, 1991; Vavilin, Vasiliev, Rytov, \& Ponomarev, 1994), potencialmente indicando uma limitação para estabilização das condições de redução do sulfato em fase acidogênica. Embora a concentração de $\mathrm{H}_{2} \mathrm{~S}_{(\text {aq })}$ no ponto A (105 mg L-1; FIGURA 10-c) na subetapa VII fosse menor que os valores medidos no mesmo ponto durante as subetapas V e VI (105-171 mg L ${ }^{-1}$ ); FIGURA $10 \mathrm{a}-\mathrm{b}$ ), o baixo $\mathrm{pH}$ facilitou que o sulfeto permeasse para o interior da célula, causando efeitos tóxicos no metabolismos da população das BRS. Embora tenha havido aumento gradual do pH nas porções superiores do reator, a inibição na porção inicial do reator caracterizou um fator crucial do processo global, com base no insignificante aumento do $\mathrm{H}_{2} \mathrm{~S}_{(\mathrm{aq})}$ ao longo do reator. 
FIGURA 10 - Concentração de sulfeto dissolvido $\left(\mathrm{H}_{2} \mathrm{~S}\right.$ e $\left.\mathrm{HS}^{-}\right)$e $\mathrm{pH}$ ao longo da altura do $\mathrm{R}_{\mathrm{AS}}$ PEBD nas subetapas operacionais selecionadas: (a) V (taxa de recirculação $=38,0$ ), (b) VI (taxa de recirculação $=57,0)$ e c) VII (taxa de recirculação $=0,0)$.
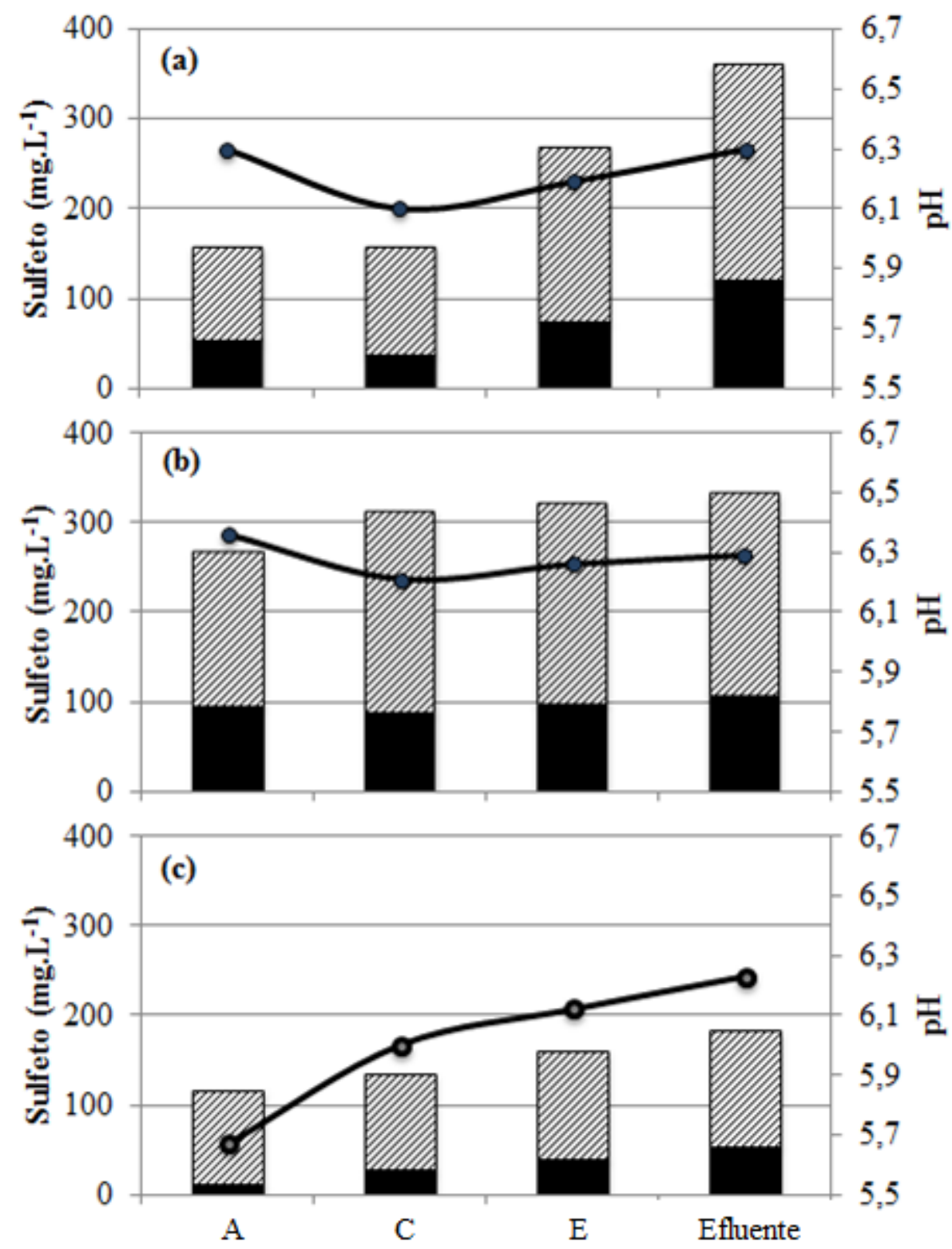

Pontos de amostragem

- $\mathrm{HS}^{-} \mathrm{\textrm {H } _ { 2 } \mathrm { S }} \rightarrow \mathrm{pH}$

A reduzida disponibilidade de alcalinidade resultou na redução da atividade sulfetogênica e impactou negativamente o metabolismo das BRS nas partes superiores. Esse resultado sugere que a maior densidade celular se acumula na parcela inferior do leito estruturado, de modo a regular o desempenho das vias de conversão realizadas dentro do sistema, como observado de maneira semelhante por Camiloti et al., (2014). Portanto, fornecer um sistema tampão balanceado é indispensável para manter um ambiente adequado 
para o estabelecimento das BRS próxima da zona de entrada. Além disso, as porções superiores mais ativas também devem ser observadas, como evidenciado pelo aumento das concentrações de sulfeto ao longo da altura do ASTBR nas subetapas V e VI (FIGURA 10ab).

Em particular, as medidas dos valores de $\mathrm{pH}$ nas etapas com aplicação da recirculação (6,13-6,37; subetapas I-VI; Tabela 11) são semelhantes aos valores ótimos de $\mathrm{pH}(6,2)$ determinado por Reis et al. (1991), que estudou a conversão acidogênica/sulfetogênica da cana-de-açúcar em condições mesofílicas $\left(35^{\circ} \mathrm{C}\right)$. Neste caso, os autores observaram variações insignificantes na produção de ácido acético ao aplicar valores de pH de 6,2 e 6,6, destacando que a manutenção de condições minimamente ácidas $(6,2)$ exigiria menos insumos alcalinos, afetando positivamente a economia do processo.

\subsubsection{ETAPA 3: RESTABELECIMENTO DO SISTEMA}

Tendo em vista a retomada do sistema para a melhor condição operacional verificada (subetapa VI; FIGURA 9, Tabela 11), a etapa 3 (subetapas VIIIa, VIIIb e IX) destinou-se ao restabelecimento do sistema. As subetapas VIIIa-b não caracterizaram-se uma fase propriamente dita, apenas com monitoramento dos principais parâmetros de controle (produção de ácidos e remoção do sulfato) e comparação do desempenho com as subetapas testadas na mesma condição (subetapas V e VI).

Decorrido os testes da subetapa VII, reintroduziu-se a recirculação ao sistema optando primeiramente aplicar a taxa de recirculação de $38,0\left(2,25 \mathrm{~m} \mathrm{~h}^{-1}\right.$, semelhante a subetapa $\left.\mathrm{V}\right)$, para que não houvesse choque e lavagem excessiva de biomassa, aumentando gradativamente a recirculação para a condição ótima verificada até o momento (subetapa VI).

O desempenho do $\mathrm{R}_{\mathrm{AS} \text {-PEBD }}$ na subetapa VIIIa foi comparada aos resultados obtidos na fase em que aplicou-se exatamente a mesma condição operacional (subetapa V). Após ter passado por um período sem recirculação, observa-se que houve redução no desempenho (FIGURA 11, Tabela 11), atingindo valor 6,08 de $\mathrm{pH}$, semelhante a subetapa VII ( $\mathrm{pH}=6,17$; Tabela 11), cuja condição apresentou reduzida atividade sulfetogênica. A exposição da biomassa ao baixo $\mathrm{pH}$ durante a etapa VII sem recirculação provavelmente afetou a redução de sulfato, atingindo valor médio de $3,39 \mathrm{~kg}_{-} \mathrm{SO}_{4} \mathrm{~m}^{-3} \mathrm{~d}^{-1}\left(4,01 \mathrm{~kg}_{-} \mathrm{SO}_{4} \mathrm{~m}^{-3} \mathrm{~d}^{-1}\right.$ subetapa V; Tabela 11). No entanto, mesmo não alcançando eficiência anteriormente testada, a reintrodução da recirculação indicou novamente ser uma estratégia viável para melhoria de sistemas acidogênicos/sulfetogênicos, de modo que a subetapa VII apresentou carga de 
sulfato removida de apenas $1,57 \mathrm{~kg}_{-} \mathrm{SO}_{4} \mathrm{~m}^{-3} \mathrm{~d}^{-1}$, melhorando o desempenho assim que a recirculação foi reintroduzida no sistema.

Quanto a produção de ácido acético identificou-se concentração de $20 \%$ abaixo do atingido na subetapa $\mathrm{V}\left(2.629 \mathrm{mg} \mathrm{L}^{-1}\right.$ subetapa V e $2.089 \mathrm{mg} \mathrm{L}^{-1}$ subetapa VIIIa; FIGURA 11-d, Tabela 11), indicando que o metabolismo sulfetogênico sofreu negativamente com a etapa sem a recirculação, não permitindo o restabelecimento do desempenho alcançado anteriormente durante a subetapa VIIIa.

Como tentativa de melhorar a remoção do sulfato, a taxa de recirculação passou para 57,0 (3,35 $\left.\mathrm{m} \mathrm{h}^{-1}\right)$, como imposto na subetapa VI, mantendo os demais parâmetros fixos. O aumento da velocidade ascensional causou impacto negativo no sistema, gerando desempenho inferior na eficiência de remoção do sulfato à subetapa VII. Uma hipótese é que a biomassa já havia sofrido estresse no período sem recirculação (fase VII), de maneira que a reinserção da recirculação provocou melhora do sistema, mas não com a mesma eficiência previamente reportada. Assim como discutido no item 5.1.2, observou-se perda de SSV relativamente mais baixa na subetapa VII do que as subetapas com recirculação. Porém, esse fato não garante que a biomassa retida no sistema ainda se manteve ativa após a exposição às condições de estresse. A limitação pode ser notada, pois o pH médio da subetapa VIIIb esteve em torno de 6,3 , cujo valor encontrou-se próximo a condição ótima de operação na subetapa VI $(6,28)$. No entanto, enquanto a subetapa VI apresentou $\mathrm{ER}_{\mathrm{SO} 4}$ de 57,3\%, a mesma condição operacional na subetapa VIIIb alcançou valor de apenas 23,0\%, identificando limitação da biomassa e não inibição por pH. Mesmo com baixa concentração de STD (STD = $162 \mathrm{mg} \mathrm{L}^{-1}$, $\mathrm{H}_{2} \mathrm{~S}=110 \mathrm{mg} \mathrm{L}^{-1}$ e $\mathrm{HS}^{-}=52 \mathrm{mg} \mathrm{L}^{-1}$ - subetapa VIIIb; Tabela 10), o reator apresentou queda no desempenho, comparado a subetapa anterior.

As subetapas VIIIa e VIIIb não apresentaram significativa perda de sólidos, respectivamente com 92 e $72 \mathrm{mg}_{\mathrm{SSV} \mathrm{L}}{ }^{-1}$, o que também evidencia que os efeitos negativos não estão associados à lavagem de biomassa e possivelmente inativação dos microrganismos submetidos às condições sem recirculação.

Devido ao desempenho insatisfatório observado durante as subetapas VIIIa e VIIIb, optou-se em aumentar o TDH para 15 h, como já mencionado anteriormente e relatado por Polo et al. (2006) sobre a baixa atividade de redução de sulfato em reduzidos TDHs. 
FIGURA 11 - Resultados operacionais referentes à etapa 3 do reator acidogênico/sulfetogênico com PEBD como material suporte PEBD (a) Carga orgânica volumétrica removida; (b) Carga de sulfato volumétrica removida; (c) Sulfeto; (d) ÁVT .
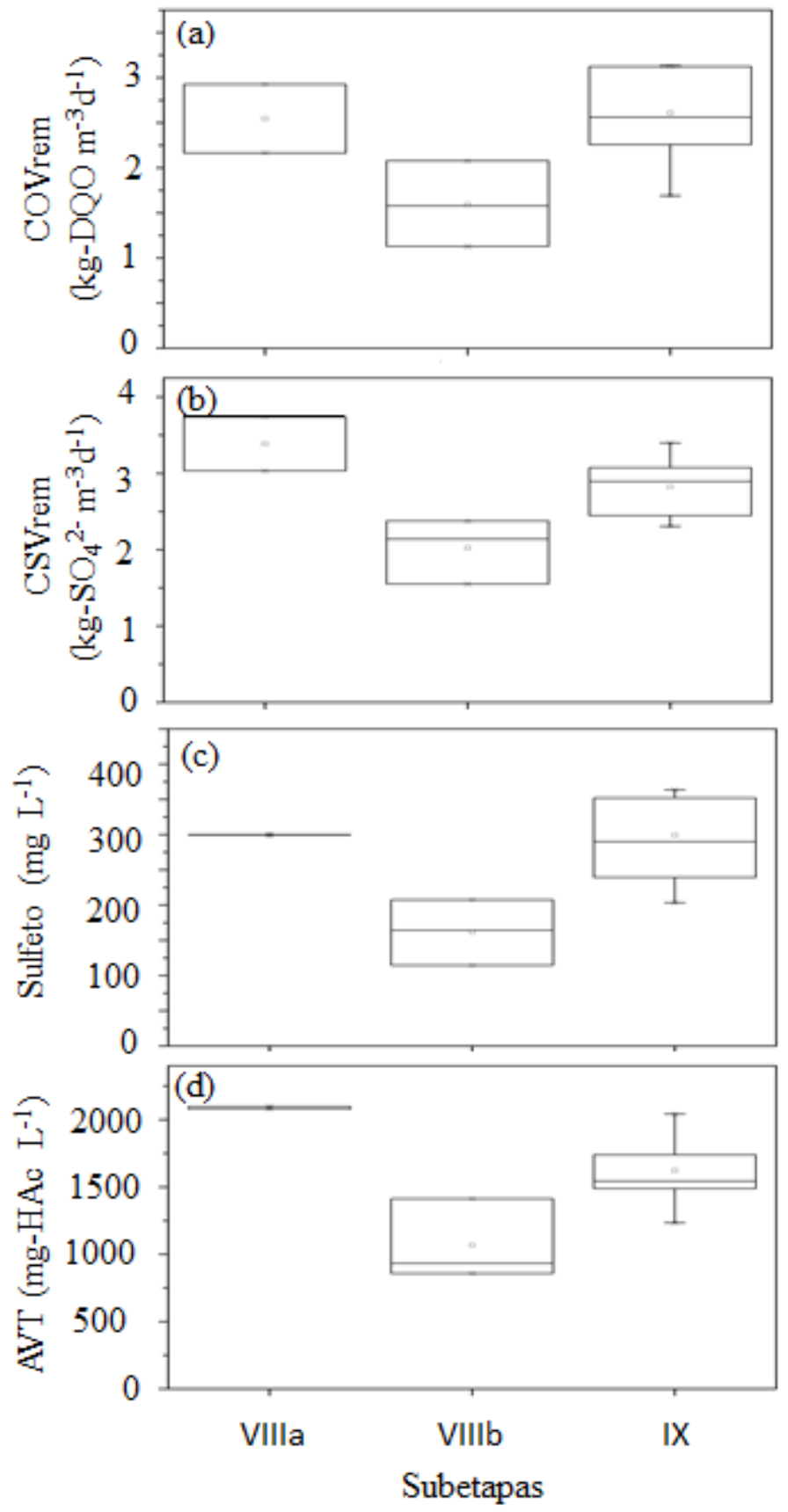

O desempenho do reator em termos de CSVrem, COVrem e AVT na subetapa IX apresentou eficiência inferior que a subetapa VIIIa, ainda com TDH de 12 horas. Uma hipótese para o melhor desempenho da subetapa VIIIa é a menor relação DQO/SO ${ }_{4}^{2-}(2,05$ na fase VIIIa e 2,41 na subetapa IX), o que pode ter favorecido a atividade sulfetogênica, mesmo em $\mathrm{pH}$ mais baixo. 
Os parâmetros de monitoramento indicaram possível limitação da biomassa decorrente à exposição em uma situação de estresse, possivelmente devido ao gradiente de $\mathrm{pH}$ formado ao longo da altura do reator em condição sem recirculação durante a subetapa VII (FIGURA 10-c), de modo que um pH favorável na primeira porção do reator rege seu desempenho global, como observado por Damianovic et al. (2016), que identificaram que a redução do sulfato ocorreu na primeira parte do reator, com escoamento tendendo a pistonado.

O baixo TDH não é indicado devido à elevada velocidade ascensional que o sistema pode gerar (devido à velocidade ascensional exercida pela vazão de alimentação), causando lavagem da biomassa além do curto tempo para reação de redução do sulfato pela via biológica. Ampliar o TDH de 12 para 15 horas foi uma estratégia adotada a fim avaliar a hipótese apresentada (TDH mais elevados são mais favoráveis às BRS) e as condições para recuperar a biomassa e atuação do metabolismo sulfetogênico, além de não estender para longos períodos que inviabilizasse uma aplicação futura de um sistema com separação de fases (acidogênico/sulfetogênico e metanogênico). Com o aumento do TDH, a vazão de recirculação foi mantida como na subetapa VIIIb e reduziu-se a vazão de alimentação, o que não resultou em variação significativa na velocidade ascensional $\left(3,35 \mathrm{~m} \mathrm{~h}^{-1}\right.$ - subetapa VIIIb e 3,34 $\mathrm{m} \mathrm{h}^{-1}$ - subetapa IX; Tabela 11). Apesar da taxa de recirculação passar de 57,0 para 72,8 , a recirculação não foi um fator significativamente alterado, comparada a fase anterior. As cargas orgânicas e de sulfato afluente foram mantidas, porém ajustando as concentrações para o novo TDH (15 horas).

Para manter a CSV $\left(8 \mathrm{~kg}-\mathrm{SO}_{4} \mathrm{~m}^{-3} \mathrm{~d}^{-1}\right)$ e $\mathrm{COV}\left(20 \mathrm{~kg}-\mathrm{DQO} \mathrm{m}^{-3} \mathrm{~d}^{-1}\right)$, a concentração de

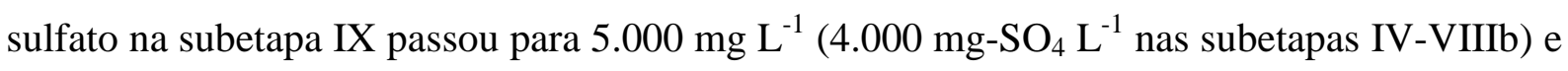
DQO de $12.500 \mathrm{mg} \mathrm{L}^{-1}$ (10.000 mg-O $\mathrm{L}^{-1}$ subetapas IV-VIIIb), devido alteração do TDH.

Essa estratégia causou um aumento de 39,60\% na eficiência de remoção de sulfato $\left(\mathrm{CSVrem}=2,82 \mathrm{~kg}-\mathrm{SO}_{4} \mathrm{~m}^{-3} \mathrm{~d}^{-1} ; \mathrm{SO}_{4 \mathrm{rem}}=1692,71 \mathrm{mg} \mathrm{L}^{-1}\right)$ e 52,05\% na produção de ácido acético ( $1.624 \mathrm{mg} \mathrm{L}^{-1}$ ), confirmando que mesmo com uma biomassa fragilizada, o TDH foi um parâmetro importante de ser manipulado para recuperação do sistema, sugerindo recuperação da biomassa.

Os resultados indicaram que utilizar o par recirculação e TDH como estratégias no estabelecimento e otimização de sistemas acidogênicos/sulfetogênico, favorece a mistura e transferência de massa, reduzindo os efeitos causados pela formação de um gradiente de $\mathrm{pH}$ e sulfeto, além do TDH mais elevado proporcionar um período adequado para as reações de 
redução do sulfato. Junto a esses fatores, a manutenção de uma baixa relação $\mathrm{DQO} / \mathrm{SO}_{4}$ tem contribuído para o desempenho da atividade sulfetogênica, o que resulta em maiores eficiências de remoção do sulfato e produção de ácido acético.

\subsubsection{ETAPA 4: MINIMIZAÇÃO DA CONCENTRAÇÃO DE SULFATO RESIDUAL NO} EFLUENTE

As etapas reportadas anteriormente obtiveram eficiência máxima de CSVrem em torno de 57,3\% (subetapa VI, Tabela 11), resultando em uma concentração residual não viável para aplicação em reator metanogênico de segunda fase, devido ao potencial de geração de sulfeto no biogás rico em metano.

Como abordagem dessa etapa, focou-se na redução da concentração de sulfato no afluente para níveis próximos ao removido na subetapa IX (aproximadamente 2.000 mg-SO $\left.\mathrm{L}^{-1}\right)$. Assim, fixaram-se todos os demais parâmetros como na subetapa IX e variou-se a concentração de sulfato para $2.000 \mathrm{mg}_{-} \mathrm{SO}_{4} \mathrm{~L}^{-1}\left(\mathrm{CSV}_{\mathrm{afl}}=3,2 \mathrm{~kg}-\mathrm{SO}_{4} \mathrm{~m}^{-3} \mathrm{~d}^{-1}\right.$, subetapa $\mathrm{X}$; Tabela 11) e $3.000 \mathrm{mg}_{-} \mathrm{SO}_{4} \mathrm{~L}^{-1}\left(\mathrm{CSV}_{\mathrm{afl}}=4,8 \mathrm{~kg}-\mathrm{SO}_{4} \mathrm{~m}^{-3} \mathrm{~d}^{-1}\right.$, subetapa XI; Tabela 11).

As eficiências de remoção de sulfato tiveram valores médios de 93,7\% $\left(\mathrm{CSV}_{\mathrm{rem}}=2,76\right.$ $\mathrm{kg}_{-} \mathrm{SO}_{4} \mathrm{~m}^{-3} \mathrm{~d}^{-1}$ - subetapa X;) e 71,8 \% (subetapa XI) (Tabela 11). Embora a eficiência na subetapa $X$ tenha resultado em menor porcentagem de sulfato residual $(6,3 \%$ de sulfato residual), a subetapa XI apresentou maior carga de sulfato removida $\left(2,76 \mathrm{~kg}_{-} \mathrm{SO}_{4} \mathrm{~m}^{-3} \mathrm{~d}^{-} 1\right.$ subetapa X e 3,43 $\mathrm{kg}_{-} \mathrm{SO}_{4} \mathrm{~m}^{-3} \mathrm{~d}^{-1}$ subetapa XI; FIGURA 12-b,Tabela 11). Dois fatores podem justificar a melhoria no desempenho durante a subetapa com maior carga de sulfato (subetapa $\mathrm{XI}$ ): a menor relação $\mathrm{DQO} / \mathrm{SO}_{4}{ }^{2-}$ pode ter proporcionado condição mais favorável para atuação das BRS (DQO/SO ${ }_{4}{ }^{2-}=6,31$ - subetapa X; $\mathrm{DQO} / \mathrm{SO}_{4}{ }^{2-}=3,84$ - subetapa XI; baseada nos dados expressos na Tabela 11) e adaptação da biomassa às condições operacionais sob TDH de 15 horas, retomando a atividade do sistema anteriormente afetado pela subetapa sem recirculação. Observou-se que o SSV mantiveram valores baixos, indicando reduzida lavagem

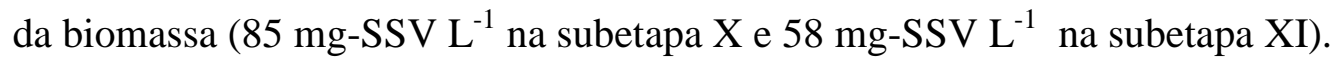

A CSVrem na subetapa $X$ apresentou-se inferior à removida na subetapa IX, sendo que a concentração afluente aplicada na subetapa $X$ manteve valor próximo a capacidade de remoção na subetapa anterior (em torno de $2000 \mathrm{mg} \mathrm{L}^{-1}$ - subetapa IX), o que não indica uma limitação da biomassa. Adotou-se essa estratégia a fim de verificar se o sistema manteria a concentração da etapa IX, o que trouxe como resposta um residual de apenas 6,3 \% na subetapa X. O potencial de geração de sulfeto também foi um fator reduzido, devido a 
diminuição da concentração de sulfato afluente de 5.000 para $2.000 \mathrm{mg}_{-} \mathrm{SO}_{4} \mathrm{~L}^{-1}$ (subetapa $\mathrm{X}$ ). $\mathrm{O}$ pH mantido em torno de 6,4 durante a subetapa $\mathrm{X}$ foi o maior valor médio obtido ao longo de toda a operação do $\mathrm{R}_{\mathrm{AS} \text {-PEBD}}$, sendo considerado um valor ainda mais favorável para a atuação das BRS. O fato de aumentar (em relação à subetapa IX) em 2,5 vezes a relação $\mathrm{DQO} / \mathrm{SO}_{4}{ }^{2-}(6,31$ na subetapa $\mathrm{X})$ pode ter desfavorecido o metabolismo sulfetogênico, e por isso apresentar uma carga de sulfato removida do que a subetapa XI, cuja relação $\mathrm{DQO} / \mathrm{SO}_{4}{ }^{2-}$ aplicada foi reduzida para aproximadamente 3,84 .

Em termos de carga de sulfato removida, a subetapa XI apresentou melhores resultados, aumentando a geração de ácidos voláteis totais. No entanto, a fração residual de sulfato manteve valores próximos a 30\%, o que torna inviável a aplicação em reator metanogênico, devido à formação de sulfeto no biogás final. Já o desempenho do reator na subetapa $X$ resultou em sulfato residual menor que 7\%, sendo um efluente atrativo devido a menor concentração de sulfato remanescente e sulfeto no efluente do reator ASTBR.

A vinhaça de cana-de-açúcar tem uma variação na concentração de sulfato ao longo da safra, variando de usina para usina. Em um levantamento realizado por Fuess et al. (2017d) a caracterização da vinhaça produzida por quatro usinas brasileiras resultou em concentrações de sulfato de 1.300-3800 mg-SO $\mathrm{L}^{-1}$. As concentrações verificadas nas subetapas X e XI se enquadram na faixa identificada pelas caracterizações. Desta forma, o potencial de redução da concentração de sulfato residual no efluente torna o processo atrativo para aplicação em uma água residuária com concentrações semelhantes, como a vinhaça. 
FIGURA 12 - Resultados operacionais referentes à etapa 4 do reator acidogênico/sulfetogênico com PEBD como material suporte PEBD (a) Carga orgânica volumétrica removida; (b) Carga de sulfato volumétrica removida; (c) Sulfeto; (d) AVT.
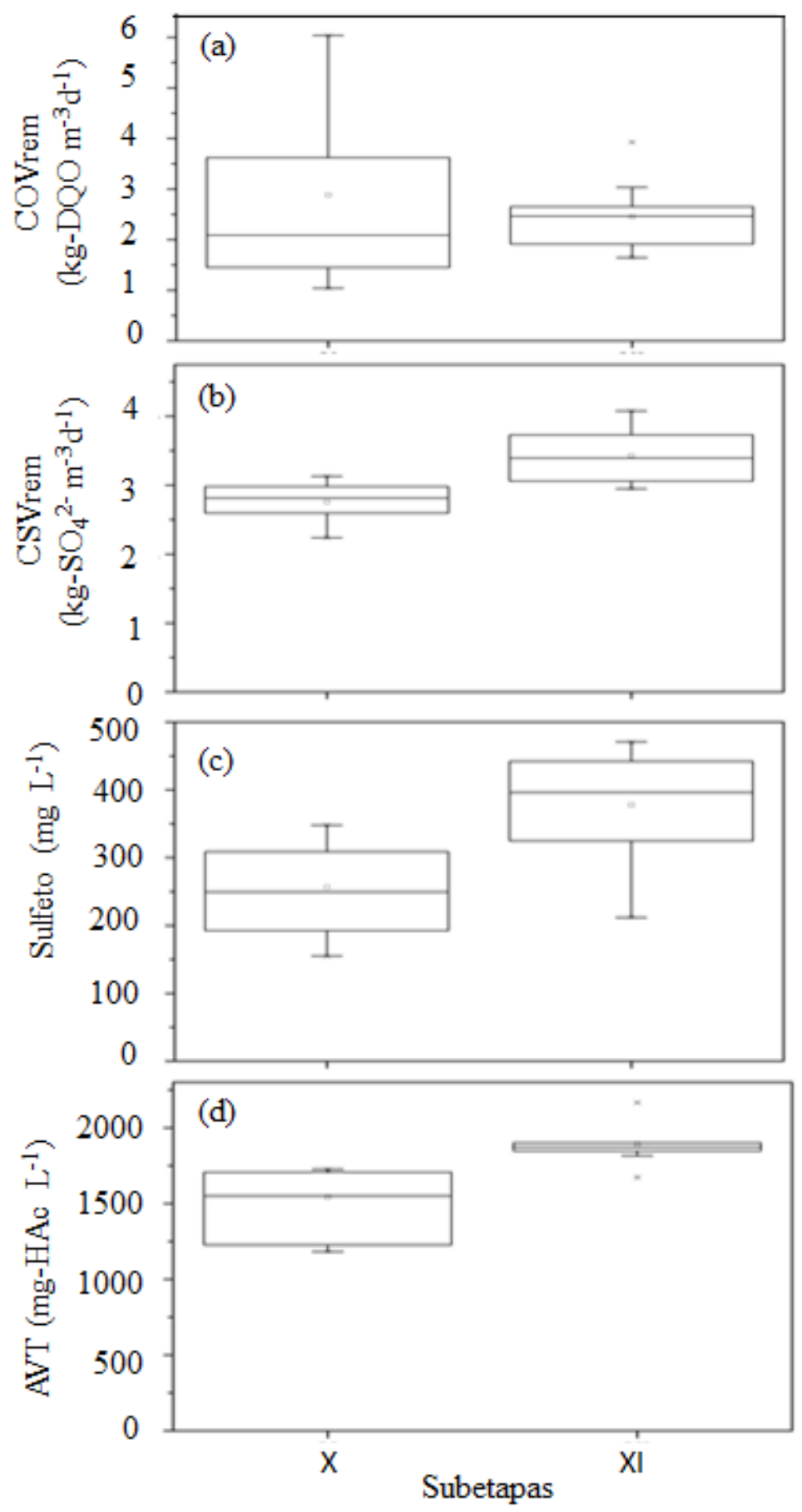

\subsubsection{ETAPA 5: REDUÇÃO DA CARGA ORGÂNICA VOLUMÉTRICA APLICADA}

As subetapas I-XI mantiveram COV em torno de $20 \mathrm{~kg}$-DQO $\mathrm{m}^{-3} \mathrm{~d}^{-1}$, como estratégia para inibir a atividade metanogênica (discussão no item 5.1.6 Biogás) no primeiro estágio do sistema de tratamento (reator acidogênico/ sulfetogênico). Na subetapa XII, da etapa 5, a 
COV afluente foi reduzida para $50 \%$ da anterior, sendo aplicada $10 \mathrm{~kg}-\mathrm{DQO} \mathrm{m} \mathrm{m}^{-3} \mathrm{~d}^{-1}$ resultando em uma relação $\mathrm{DQO} / \mathrm{SO}_{4}{ }^{2-}$ efetiva próxima a 2 . Os demais parâmetros foram mantidos como na subetapa XI.

A redução da carga orgânica no reator acidogênico/sulfetogênico de 20 para 10 kgDQO $\mathrm{m}^{-3} \mathrm{~d}^{-1}$ manteve a inibição da atividade metanogênica como requerido, sendo que a carga orgânica volumétrica removida se deu pela via sulfetogênica, como desejado para o reator de primeira fase. O estabelecimento da rota metanogênica resultaria em maior remoção da matéria orgânica e redução da concentração de ácidos no efluente, o qual manteve concentração similar à subetapa anterior (AVT de $1.892 \mathrm{mg} \mathrm{L}^{-1}$ - subetapa XI e $1.860 \mathrm{mg} \mathrm{L}^{-1}$ - subetapa XII; Tabela 11). A inibição da metanogênese provavelmente resultou da baixa relação $\mathrm{DQO} / \mathrm{SO}_{4}$, além do $\mathrm{pH}$ médio abaixo do ótimo para sua atuação.

A eficiência de remoção da DQO foi a maior desde o início da operação, porém a concentração afluente compreendeu valores próximos a $6.250 \mathrm{mg} \mathrm{L}^{-1}$, sendo a COVrem de aproximadamente $11,5 \%$ acima que a subetapa XI. A concentração de STD atingiu o maior valor médio em toda a operação do reator $\left(\mathrm{STD}=429 \mathrm{mg} \mathrm{L}^{-1}, \mathrm{H}_{2} \mathrm{~S}=283 \mathrm{mg} \mathrm{L}^{-1}\right.$ e $\mathrm{HS}^{-}=146$ mg L ${ }^{-1}$; FIGURA 10, Tabela 11), mantendo a porcentagem de 53\% do STD retido na fase líquida (como na subetapa XI), sendo mais um fator inibidor para atuação das metanogênicas. $\mathrm{O}$ etanol residual esteve próximo a $45 \%$, similar às porcentagens das subetapas $\mathrm{V}$ e VI (47,67\% - subetapa V e 41,10 - subetapa VI, Tabela 11).

A redução da COVafl não foi um fator que contribuiu para o estabelecimento da atividade metanogênica, como relatado em alguns trabalho. A reduzida relação DQO/ $\mathrm{SO}_{4}{ }^{2-}$ foi determinante para o prevalecimento da atividade sulfetogênica no sistema, além de manter uma elevada concentração de sulfeto e $\mathrm{pH}$ ligeiramente ácido $(\mathrm{pH}=6,31$ - subetapa XII; Tabela 11), condições desfavoráveis para a produção de metano, cujo pH ótimo para atuação das metanogênicas varia de 7-7,5 (Zhang \& Maekawa, 1996). 
FIGURA 13 - Resultados operacionais referentes às 5 etapas do reator acidogênico/sulfetogênico com PEBD como material suporte PEBD (a) Carga orgânica volumétrica removida; (b) Carga de sulfato volumétrica removida; (c) Sulfeto; (d) AVT .
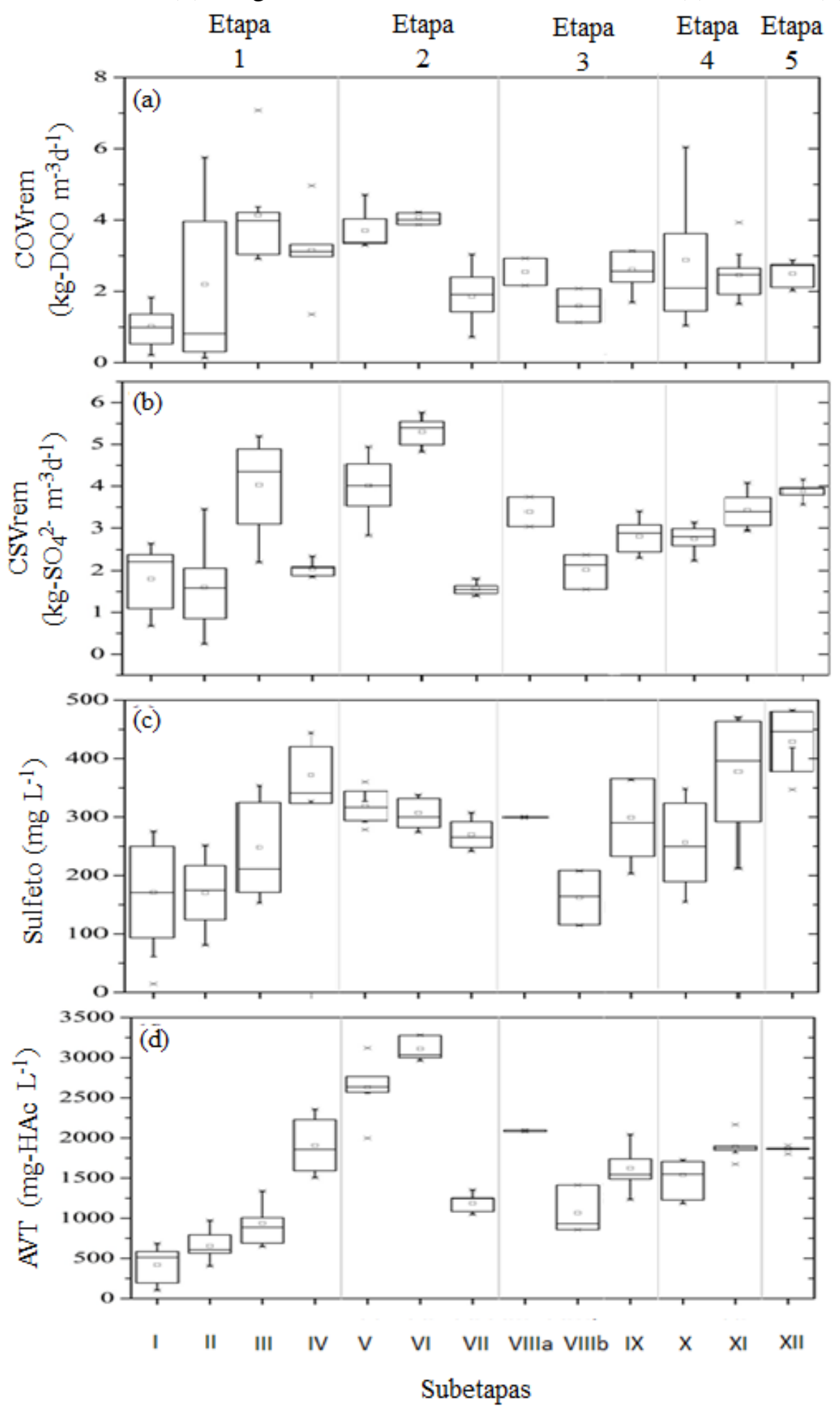


\subsubsection{COMPOSIÇÃO DO BIOGÁS DO REATOR ACIDOGÊNICO/SULFETOGÊNICO COM PEBD COMO MATERIAL SUPORTE}

A composição do biogás serviu para auxiliar na compreensão da redução de sulfato sob condição acidogênica, de forma que as porcentagens calculadas em cada uma das subetapas foram reflexo das estratégias operacionais. A vazão de biogás foi baixa (abaixo do limite de detecção do medidor de gás, ou seja, $<1 \mathrm{~mL} \mathrm{~h}^{-1}$ ) durante todo o período de operação, o que impossibilitou a determinação do volume de gás produzido. Com exceção da subetapa I, o $\mathrm{H}_{2} \mathrm{~S}$ prevaleceu na composição do biogás nas subetapas seguintes. Observou-se que a subetapa I manteve uma elevada porcentagem de metano, esperada em função da fonte de inóculo. Provavelmente a presença do metano se deu como resultado da degradação endógena de biomassa não aderida (remanescente da inoculação), acumulada na parte inferior do reator (FIGURA 3). A remoção da biomassa acumulado cessou a detecção de $\mathrm{CH}_{4}$ no biogás após aproximadamente 30 dias de operação, confirmando que o estabelecimento de população metanogênica não foi favorecido no sistema.

O sulfeto produzido não foi totalmente transferido para fase gasosa, já que uma fração ainda permanecia na forma dissociada $\mathrm{HS}^{-}$e $\mathrm{H}_{2} \mathrm{~S}$ retidas no líquido, além de uma parcela poder ter precipitado com metais (parcela não analisada no presente trabalho) presentes na água residuária sintética e também assimilado por microrganismos.

A proporção de $\mathrm{H}_{2} \mathrm{~S}$ no biogás aumentou acentuadamente de 3,37\% (subetapa I) para $49,81 \%$ (subetapa II) à medida que a CSV aumentou de 8,0 para $12,0 \mathrm{~kg}-\mathrm{SO}_{4}{ }^{2-} \mathrm{m}^{-3} \mathrm{~d}^{-1}$ (FIGURA 14) e o metano desapareceu, o que comprova que as condições foram favoráveis à inibição da atividade metanogênica e estabelecimento das condições sulfetogênicas. No entanto, o aumento da CSV para $16,0 \mathrm{~kg}_{-} \mathrm{SO}_{4}{ }^{2-} \mathrm{m}^{-3} \mathrm{~d}^{-1}$ (subetapa III) e TDH para $12 \mathrm{~h}$ (subetapa IV) apenas afetou ligeiramente a composição do biogás, com valores na proporção de $\mathrm{H}_{2} \mathrm{~S}$ variando entre 70,01-76,72 em valores médios (FIGURA 14), contando ainda na subetapa IV com uma insignificante contribuição de metano $(0,23 \%)$, provavelmente como efeito do aumento do TDH. Esse comportamento corrobora com os padrões observados durante o monitoramento da fase líquida, o que indicou a necessidade de aplicar estratégias operacionais adicionais para efetivamente melhorar à atividade sulfetogênica dentro do reator, como a recirculação do efluente. 
FIGURA 14 - Composição do biogás gerado no reator ASTBR com PEBD

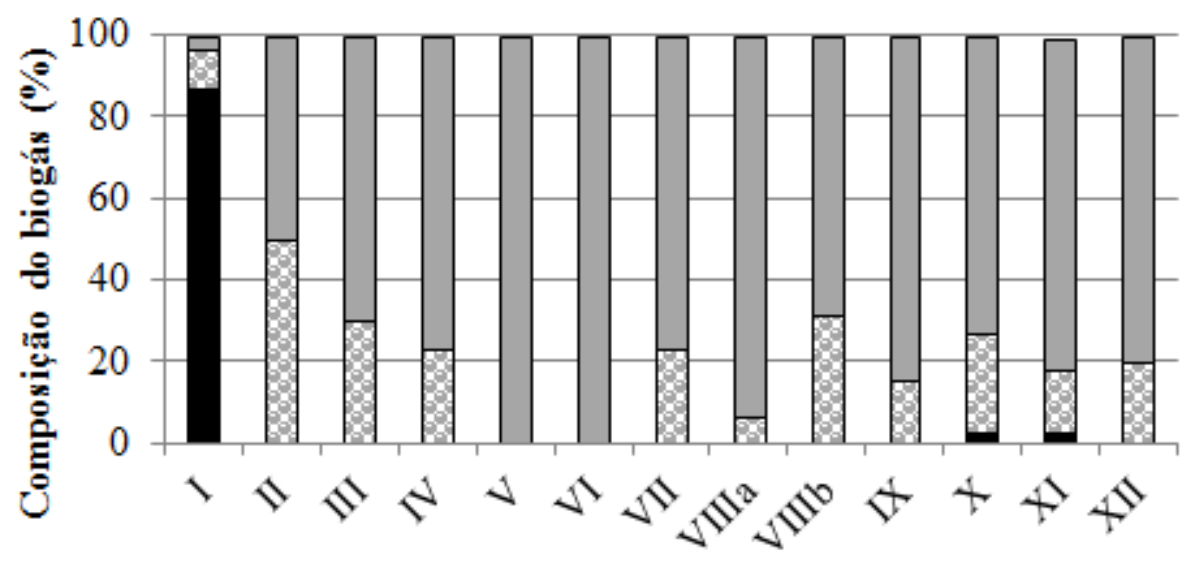

Subetapas

a $\mathrm{CH}_{4} \quad \boxminus \mathrm{CO}_{2} \quad \square \mathrm{H}_{2} ; \mathrm{S}$

De fato, a proporção de $\mathrm{H}_{2} \mathrm{~S}$ no biogás aumentou para praticamente $100 \%$ durante as subetapas V e VI (FIGURA 14), o que confirma os benefícios da recirculação da fase líquida para operação de sistemas sulfetogênico. Finalmente, a proporção de $\mathrm{H}_{2} \mathrm{~S}$ diminuiu ainda mais para 76,66\% na subetapa VII, com a detecção simultânea de $\mathrm{CO}_{2}(23,34 \%)$ (FIGURA 14). Esse padrão provavelmente resultou da queda de $\mathrm{pH}$ observada quando não foi aplicada recirculação do efluente $\left(\mathrm{pH}=6,06\right.$; FIGURA 11), deslocando íons $\mathrm{HCO}_{3}{ }^{-}$para formar $\mathrm{CO}_{2}$, dado que o valor de pKa para o par $\mathrm{CO}_{2} / \mathrm{HCO}_{3}{ }^{-}$é de aproximadamente 6,29 a $55^{\circ} \mathrm{C}$ (Speece, 1996).

A fase de reintrodução da recirculação (subetapa VIIIa) provocou redução da proporção de $\mathrm{CO}_{2}$ no biogás (6,65\% de $\mathrm{CO}_{2}$ e 93,35\% de $\mathrm{H}_{2} \mathrm{~S}$; FIGURA 14), mas ainda influenciada por reduzido pH. Observou-se uma redução drástica para 68,58\% de $\mathrm{H}_{2} \mathrm{~S}$ durante a subetapa VIIIb, resultante da diminuição na atividade sulfetogênica (23\% CSVrem;Tabela $11)$.

Após a alteração do TDH para 12 h (subetapa IX) houve uma melhora na remoção de sulfato (CSVrem = 34,4; FIGURA 14), cujo desempenho similar a subetapa VIIIa, o que provocou um aumento na proporção de $\mathrm{H}_{2} \mathrm{~S}$, decorrente da melhoria do sistema.

A composição do biogás manteve proporção de metano similar nas subetapas X-XI $\left(2,68-2,73 \%\right.$ de $\left.\mathrm{CH}_{4}\right)$, possivelmente associada às maiores relações $\mathrm{DQO} / \mathrm{SO}_{4}{ }^{2}$. Quanto à proporção de $\mathrm{H}_{2} \mathrm{~S}$, manteve-se com valor médio de $72,75-80,82 \%$. 
Um fator observado nas subetapas anteriores, quando houve geração de metano esteve relacionado com a relação $\mathrm{DQO} / \mathrm{SO}_{4}{ }^{2-}$. Com a redução da relação $\mathrm{DQO} / \mathrm{SO}_{4}{ }^{2-}$ de 3,84 (subetapa XI) para 1,98 (subetapa XII) o biogás passou a ter apenas $\mathrm{CO}_{2}(19,6 \%)$ e $\mathrm{H}_{2} \mathrm{~S}(80,4)$ em sua composição, sendo a produção do metano inibida pela menor relação $\mathrm{DQO} / \mathrm{SO}_{4}{ }^{2-}$. $\mathrm{Na}$ fase XII, além da menor relação $\mathrm{DQO} / \mathrm{SO}_{4}{ }^{2-}$, outros fatores que possivelmente influenciaram na inibição da produção de metano foi à elevada concentração de STD (429 mg L ${ }^{-1}$, FIGURA 9-c) e pH (Tabela 11).

\subsubsection{RESUMO DO DESEMPENHO DO REATOR ACIDOGÊNICO/SULFETOGÊNICO COM PEBD COMO MATERIAL SUPORTE}

Nesta seção, estão reunidos os resultados operacionais das 5 etapas do reator acidogênico/sulfetogênico com PEBD como material suporte ( $\left.\mathrm{R}_{\mathrm{AS}-\mathrm{PEBD}}\right)$, sendo expressos os valores médios referente a eficiência de remoção de DQO, eficiência de remoção do sulfato, carga orgânica volumétrica afluente, carga de sulfato volumétrica afluente, carga de sulfato volumétrica removida, carga de sulfato volumétrica efluente, porcentagem de etanol residual, concentração de sulfeto total dissolvido (STD), concentração de $\mathrm{H}_{2} \mathrm{~S}$ e HS , alcalinidade parcial (AP), concentração de ácidos voláteis totais (AVT), pH e sólidos suspensos totais (SSV) (Tabela 11).

Na FIGURA 15 está expressa a distribuição da especiação do sulfeto, na forma de sulfeto total dissolvido, a forma dissociada $\left(\mathrm{HS}^{-}\right)$e a não dissociada $\left(\mathrm{H}_{2} \mathrm{~S}\right)$, sendo que os cálculos levaram em consideração a temperatura de $55^{\circ} \mathrm{C}$ e o pH para cada uma das subetapas, seguindo as equações 1 e 2 .. 
Tabela 11 - Desempenho global do reator acidogênico/sulfetogênico com PEBD como material suporte $\left(\mathrm{R}_{\mathrm{AS}-\mathrm{PEBD}}\right)$

\begin{tabular}{|c|c|c|c|c|c|c|c|c|c|c|c|c|c|}
\hline \multirow{4}{*}{ Variável-resposta } & \multicolumn{13}{|c|}{ Etapas operacionais } \\
\hline & \multicolumn{4}{|c|}{1} & \multicolumn{3}{|c|}{2} & \multicolumn{3}{|c|}{3} & \multicolumn{2}{|c|}{4} & \multirow[t]{2}{*}{5} \\
\hline & \multicolumn{12}{|c|}{ Subetapas } & \\
\hline & I & II & III & IV & $\mathrm{V}$ & VI & VII & VIIIa & VIIIb & IX & $\mathrm{X}$ & XI & XII \\
\hline $\mathrm{ER}_{\mathrm{DQO}}(\%)$ & $6,7 \pm 5,7$ & $10,8 \pm 11,5$ & $22,5 \pm 7,0$ & $19,0 \pm 8,5$ & $21,2 \pm 2,7$ & $20,9 \pm 1,0$ & $9,8 \pm 3,7$ & $13,1 \pm 2,6$ & $8,1 \pm 2,3$ & $14,4 \pm 2,6$ & $15,0 \pm 6,5$ & $13,4 \pm 3,1$ & $24,1 \pm 3,1$ \\
\hline $\mathrm{ER}_{\mathrm{SO} 4}(\%)$ & $27,5 \pm 12,7$ & $18,0 \pm 14,2$ & $26,0 \pm 7,90$ & $41,2 \pm 7,6$ & $48,7 \pm 8,4$ & $57,3 \pm 5,4$ & $25,3 \pm 12,7$ & $35,6 \pm 3,1$ & $23,0 \pm 5,7$ & $34,4 \pm 8,6$ & $93,7 \pm 4,7$ & $71,8 \pm 4,4$ & $74,6 \pm 2,2$ \\
\hline $\mathrm{COV}_{\text {afl }}\left(\mathrm{kg} \mathrm{m}^{-3} \mathrm{~d}^{-1}\right)$ & $16,17 \pm 1,11$ & $19,71 \pm 1,42$ & $18,41 \pm 1,55$ & $17,12 \pm 2$ & $\begin{array}{c}17,57 \pm \\
1,88\end{array}$ & $\begin{array}{c}19,54 \pm \\
0,35\end{array}$ & $\begin{array}{c}19,12 \pm \\
1,17\end{array}$ & $\begin{array}{c}19,46 \pm \\
0,26\end{array}$ & $\begin{array}{c}19,54 \pm \\
1,22\end{array}$ & $\begin{array}{c}18,04 \pm \\
1,39\end{array}$ & $\begin{array}{c}18,12 \pm \\
1,89\end{array}$ & $\begin{array}{c}18,34 \pm \\
1,54\end{array}$ & $\begin{array}{c}10,35 \pm \\
0,78\end{array}$ \\
\hline $\operatorname{CSV}_{\mathrm{afl}}\left(\mathrm{kg} \mathrm{m}^{-3} \mathrm{~d}^{-1}\right)$ & $6,68 \pm 0,77$ & $11,99 \pm 2,29$ & $15,62 \pm 2,33$ & $5,13 \pm 1,25$ & $8,29 \pm 0,71$ & $9,29 \pm 0,61$ & $8,61 \pm 0,52$ & $9,49 \pm 0,59$ & $8,87 \pm 0,72$ & $7,46 \pm 0,76$ & $2,87 \pm 0,38$ & $4,77 \pm 0,36$ & $5,21 \pm 0,31$ \\
\hline $\mathrm{CSV}_{\mathrm{rem}}\left(\mathrm{kg} \mathrm{m}^{-3} \mathrm{~d}^{-1}\right)$ & $1,80 \pm 0,76$ & $1,61 \pm 0,88$ & $4,03 \pm 1,15$ & $2,04 \pm 0,17$ & $4,01 \pm 0,66$ & $5,30 \pm 0,39$ & $1,57 \pm 0,16$ & $3,39 \pm 0,50$ & $2,02 \pm 0,42$ & $2,82 \pm 0,45$ & $2,76 \pm 0,29$ & $3,43 \pm 0,37$ & $3,88 \pm 0,22$ \\
\hline $\mathrm{CAV}_{\mathrm{efl}}\left(\mathrm{kg} \mathrm{m}^{-3} \mathrm{~d}^{-1}\right)$ & $1,70 \pm 0,76$ & $2,99 \pm 0,95$ & $3,99 \pm 0,93$ & $3,37 \pm 0,46$ & $5,29 \pm 0,63$ & $7,08 \pm 0,57$ & $2,58 \pm 0,18$ & $4,69 \pm 0,03$ & $2,35 \pm 0,71$ & $2,61 \pm 0,47$ & $2,52 \pm 0,41$ & $3,20 \pm 0,29$ & $3,18 \pm 0,20$ \\
\hline Etanol residual (\%) & $81,01 \pm 5,86$ & $\begin{array}{c}79,54 \pm \\
11,62\end{array}$ & $\begin{array}{c}58,21 \pm \\
10,98\end{array}$ & $\begin{array}{c}61,45 \pm \\
2,11\end{array}$ & $\begin{array}{c}47,67 \pm \\
5,03\end{array}$ & $\begin{array}{c}41,10 \pm \\
5,33\end{array}$ & $\begin{array}{c}77,71 \pm \\
5,55\end{array}$ & $\begin{array}{c}62,81 \pm \\
2,42\end{array}$ & $\begin{array}{c}79,80 \pm \\
5,76\end{array}$ & $\begin{array}{c}71,16 \pm \\
3,34\end{array}$ & $\begin{array}{c}72,41 \pm \\
7,83\end{array}$ & $\begin{array}{c}68,54 \pm \\
2,55\end{array}$ & $\begin{array}{c}45,19 \pm \\
3,02\end{array}$ \\
\hline $\operatorname{STD}\left(\mathrm{mg} \mathrm{L}^{-1}\right)$ & $172 \pm 78$ & $170 \pm 46$ & $248 \pm 77$ & $372 \pm 48$ & $319 \pm 25$ & $307 \pm 25$ & $270 \pm 22$ & $300 \pm 1$ & $162 \pm 47$ & $299 \pm 66$ & $256 \pm 67$ & $378 \pm 86$ & $429 \pm 51$ \\
\hline $\mathrm{H}_{2} \mathrm{~S}$ & $93 \pm 29$ & $119 \pm 37$ & $156 \pm 67$ & $260 \pm 39$ & $232 \pm 22$ & $207 \pm 13$ & $208 \pm 24$ & $230 \pm 8$ & $110 \pm 40$ & $209 \pm 49$ & $158 \pm 48$ & $245 \pm 56$ & $283 \pm 35$ \\
\hline $\mathrm{HS}^{-}$ & $78 \pm 63$ & $48 \pm 24$ & $98 \pm 34$ & $112 \pm 32$ & $87 \pm 8$ & $100 \pm 20$ & $62 \pm 16$ & $70 \pm 9$ & $52 \pm 6$ & $91 \pm 29$ & $99 \pm 28$ & $132 \pm 35$ & $146 \pm 19$ \\
\hline $\begin{array}{c}\mathrm{AP}\left(\mathrm{mg} \mathrm{CaCO}_{3} \mathrm{~L}^{-}\right. \\
\left.{ }^{1}\right)\end{array}$ & $98 \pm 47$ & $74 \pm 14$ & $101 \pm 26$ & $174 \pm 39$ & $189 \pm 38$ & $206 \pm 42$ & $90 \pm 15$ & $110 \pm 11$ & $131 \pm 18$ & $183 \pm 40$ & $190 \pm 23$ & $223 \pm 26$ & $240 \pm 10$ \\
\hline $\operatorname{AVT}\left(\mathrm{mg} \mathrm{L}^{-1}\right)$ & $420 \pm 199$ & $655 \pm 175$ & $936 \pm 261$ & $\begin{array}{c}1.907 \pm \\
376\end{array}$ & $\begin{array}{c}2.629 \pm \\
294\end{array}$ & $\begin{array}{c}3.111 \pm \\
155\end{array}$ & $1.187 \pm 115$ & $2.089 \pm 12$ & $\begin{array}{c}1.068 \pm \\
301\end{array}$ & $\begin{array}{c}1.624 \pm \\
272\end{array}$ & $\begin{array}{c}1.541 \pm \\
219\end{array}$ & $\begin{array}{c}1.892 \pm \\
125\end{array}$ & $1.860 \pm 38$ \\
\hline $\mathrm{pH}_{\mathrm{efl}}$ & $6,28 \pm 0,52$ & $6,13 \pm 0,25$ & $6,37 \pm 0,16$ & $6,22 \pm 0,15$ & $6,17 \pm 0,05$ & $6,28 \pm 0,09$ & $6,06 \pm 0,15$ & $6,08 \pm 0,07$ & $6,3 \pm 0,13$ & $6,23 \pm 0,12$ & $6,4 \pm 0,13$ & $6,33 \pm 0,09$ & $6,31 \pm 0,04$ \\
\hline $\operatorname{SSV}(\mathrm{mg} \mathrm{L}-1)^{*}$ & 201 & 187 & 175 & 305 & 95 & 180 & 37 & 92 & 72 & 53 & 85 & 58 & 63 \\
\hline
\end{tabular}

*A concentração de SSV são valores médios de cada uma das subetapas de operação. 
FIGURA 15 - Sulfeto estimado $\left(\mathrm{H}_{2} \mathrm{~S}+\mathrm{HS}^{-}\right)$e acumulado na fase líquida de acordo com cada fase operacional do reator acidogênico/sulfetogênico de PEBD. Nota: Calculo da produção de sulfeto teórico assumindo que $1 \mathrm{~g}$ de $\mathrm{SO}_{4}{ }^{2-}$ reduzido produz $0,33 \mathrm{~g}$ de sulfeto total.

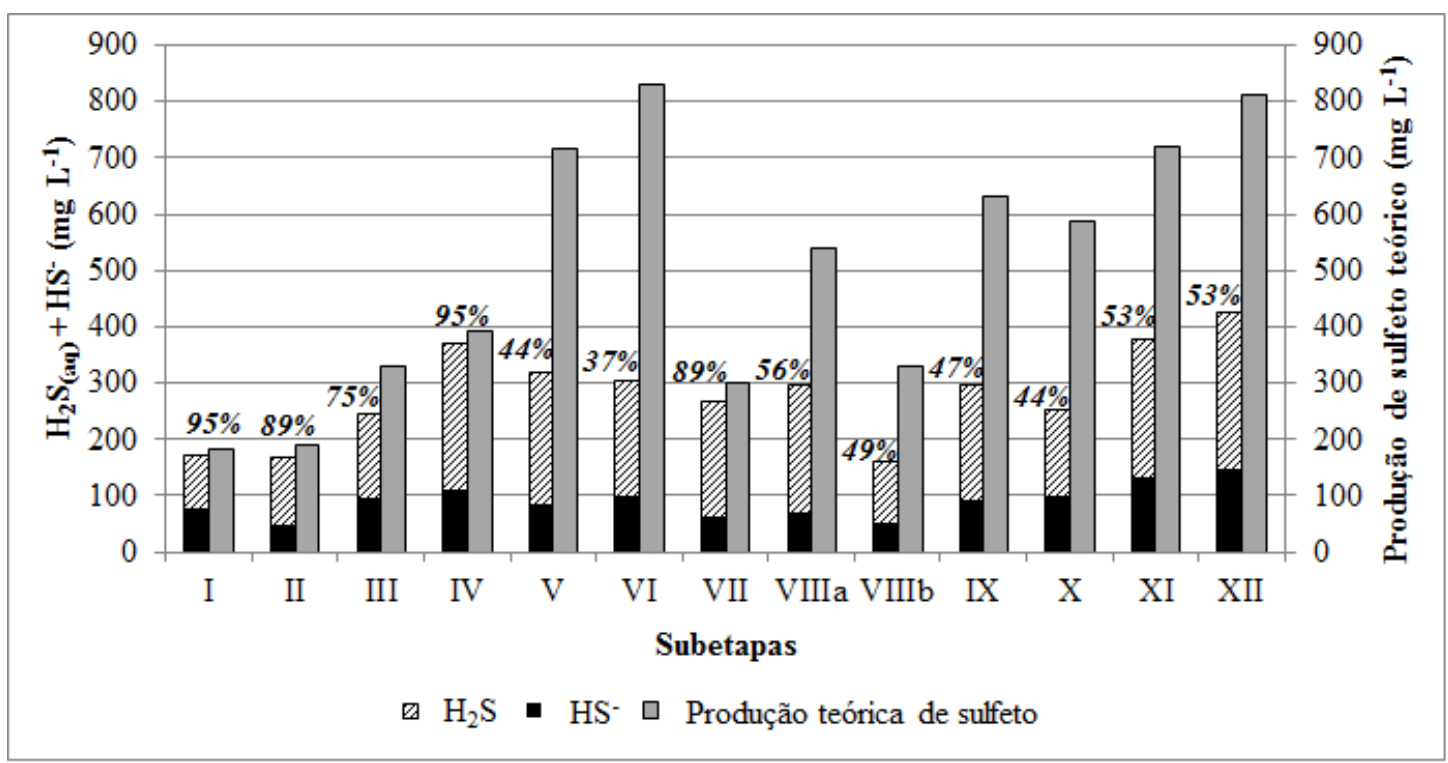

\subsection{Reatores acidogênicos/sulfetogênico com espuma de poliuretano (PU) como material suporte $\left(\mathbf{R}_{\mathrm{AS}-\mathrm{PU}}\right)$}

Devido à baixa eficiência de remoção do sulfato verificada na etapa 1 de operação do reator acidogênico/sulfetogênico com PEBD ( $\left.\mathrm{R}_{\mathrm{AS}-\mathrm{PEBD}}\right)$, uma hipótese foi levantada quanto ao material suporte. A área superficial do material suporte de PEBD utilizado no $\mathrm{R}_{\mathrm{AS} \text {-PEBD }}$ não teria sido suficiente para retenção de uma concentração de biomassa necessária para atingir elevada eficiência de remoção do sulfato em curto prazo. Portanto, a estratégia para avaliar esse fato foi aplicar a espuma de poliuretano, com maior área superficial que o material suporte testado anteriormente.

Silva et al. (2006) avaliaram a adesão de BRS em diversos materiais suportes, sendo que a espuma de poliuretano resultou em uma das melhores remoções de sulfato, com eficiência em torno de $39 \%$ e maior concentração de biomassa por grama de material suporte, sob condição mesofílica $\left(30^{\circ} \mathrm{C}\right)$. De fato, a espuma de PU resultou em maior adesão de biomassa no $\mathrm{R}_{\mathrm{AS}-\mathrm{PU}}$, com concentração ao final da operação de $1,2 \mathrm{~g}$ de $\mathrm{STV} \mathrm{g}^{-1}$ de suporte, representando $90,8 \%$ da biomassa total retida no reator. Para o reator $\mathrm{R}_{\mathrm{AS}-\mathrm{PEBD}}$, a proporção esteve em aproximadamente em 0,072 g de STV/g suporte (aproximadamente 76,20\% do total de STV). As estratégias operacionais adotadas basearam-se em experiência adquirida com o $\mathrm{R}_{\mathrm{AS}-\mathrm{PEBD}}$, cujas variações de carga de sulfato volumétrica, TDH e velocidade ascensional foram as principais condições em que apresentaram alterações positivas no sistema. No 
entanto, as estratégias não foram suficientes para atingir uma rápida partida e eficiente remoção do sulfato como esperado. A seguir, estão descritas as estratégias executadas e as resposta a cada alteração no $\mathrm{R}_{\mathrm{AS}-\mathrm{PU} \text {. }}$

Como sistemas termofílicos apresentam limitação de crescimento comparado aos mesofílico, a espuma de PU seria uma alternativa para maior colonização e retenção no suporte do que o PEBD. Adotaram-se para partida do $\mathrm{R}_{\mathrm{AS}-\mathrm{PU}}$, as estratégias de sucesso aplicadas no $\mathrm{R}_{\mathrm{AS}-\mathrm{PEBD}}$, como maior TDH e velocidade ascensional acima de $3 \mathrm{~m} \mathrm{~h}^{-1}$. Porém, a aplicação de um material suporte com maior área superficial e com condições anteriormente otimizadas no reator acidogênico com PEBD não propiciou melhor desempenho, de forma que a maior eficiência de remoção do sulfato alcançado ao longo de todo o período operacional do $\mathrm{R}_{\mathrm{AS}-\mathrm{PU}}$ esteve em média de 46,84\% (etapa IV, Tabela 12). A condição operacional incialmente aplicada apresentou uma velocidade ascensional de $3,42 \mathrm{~m} \mathrm{~h}^{-1} \mathrm{e}$ $\mathrm{DQO} / \mathrm{SO}_{4}{ }^{2-}$ de 2,5 (etapa I - $\mathrm{R}_{\mathrm{AS}-\mathrm{PU}}$; Tabela 3 ).

Levando em consideração a baixa eficiência de remoção em TDH de 6 horas no $\mathrm{R}_{\mathrm{AS}}$ PEBD, adotou-se como estratégia para a partida do $\mathrm{R}_{\mathrm{AS}-\mathrm{PU}}$ nas etapas I e II manter o TDH de 12 horas e COV afluente (teórica) em torno de $20 \mathrm{~kg}$-DQO $\mathrm{m}^{-3} \mathrm{~d}^{-1}$. Nos primeiros 45 dias, a CSV afluente permaneceu em $8 \mathrm{~kg}-\mathrm{SO}_{4}{ }^{2-} \mathrm{m}^{-3} \mathrm{~d}^{-1}\left(\mathrm{DQO} / \mathrm{SO}_{4}{ }^{2-}=2,5,4.000 \mathrm{mg}-\mathrm{SO}_{4}{ }^{2-} \mathrm{L}^{-1}\right.$; Tabela 3), sendo que a eficiência de remoção do sulfato esteve abaixo de $15 \%$ durante a etapa I. A mesma condição aplicada ao $\mathrm{R}_{\mathrm{ASI}-\mathrm{PEBD}}$ atingiu eficiência de remoção superior a $57 \%$.

Como se tratava da etapa inicial do reator, a diversidade microbiana ainda não se encontrava adaptada às condições acidogênicas/sulfetogênicas impostas (sendo o inóculo proveniente de sistemas metanogênicos), tendo como possibilidade a inibição causada pelo sulfeto a partir da redução do sulfato no sistema (125 mg L ${ }^{-1}$ - etapa I FIGURAS 16 e 17, Tabela 12). Em alguns sistemas, concentrações mais elevadas de sulfeto que às obtidas na etapa I não causaram inibição ao processo (Barrera et al., 2014). Mesmo exposta a uma baixa relação $\mathrm{DQO} / \mathrm{SO}_{4}$, o que ajudaria a selecionar microrganismos redutores de sulfato, os resultados sugerem inibição por sulfeto, destacando que a biomassa ainda estava em estágio de adaptação e provavelmente ainda não apresentava concentração de microrganismos redutores de sulfato e tolerantes ao sulfeto. Apenas 38,24\% da COV removida na etapa I seguiu a via sulfetogênica, o que é aceitável no período de partida de um reator biológico. Nesse período, os microrganismos utilizam fonte de carbono para síntese celular e produção 
de biopolímeros para estruturação da biomassa (Michaud, Bernet, Buffière, Roustan, \& Moletta, 2002).

Tabela 12 - Desempenho global do reator acidogênico/sulfetogênico com espuma de PU como material suporte $\left(\mathrm{R}_{\mathrm{AS}-\mathrm{PU}}\right)$

\begin{tabular}{|c|c|c|c|c|}
\hline \multirow{2}{*}{ Variável-resposta } & \multicolumn{4}{|c|}{ Etapas operacionais } \\
\hline & I & II & III & IV \\
\hline $\mathrm{ER}_{\mathrm{DQO}}(\%)$ & $11,06 \pm 3,28$ & $11,87 \pm 3,19$ & $9,4 \pm 4,27$ & $11,54 \pm 3,06$ \\
\hline $\mathrm{ER}_{\mathrm{SO} 4}(\%)$ & $14,08 \pm 3,28$ & $44,68 \pm 10,51$ & $39,35 \pm 8,38$ & $46,84 \pm 6,92$ \\
\hline $\operatorname{COV}_{\mathrm{afl}}\left(\mathrm{kg} \mathrm{m}^{-3} \mathrm{~d}^{-1}\right)$ & $19,18 \pm 1,27$ & $15,61 \pm 1,95$ & $14,89 \pm 1,90$ & $15,93 \pm 0,97$ \\
\hline $\mathrm{CSV}_{\mathrm{afl}}\left(\mathrm{kg} \mathrm{m}^{-3} \mathrm{~d}^{-1}\right)$ & $8,65 \pm 0,70$ & $3,36 \pm 0,31$ & $3,93 \pm 0,84$ & $4,340,35$ \\
\hline $\mathrm{CSV}_{\text {rem }}\left(\mathrm{kg} \mathrm{m}^{-3} \mathrm{~d}^{-1}\right)$ & $1,21 \pm 0,24$ & $1,49 \pm 0,32$ & $1,51 \pm 0,28$ & $2,04 \pm 0,41$ \\
\hline $\mathrm{CAV}_{\mathrm{efl}}\left(\mathrm{kg} \mathrm{m}^{-3} \mathrm{~d}^{-1}\right)$ & $1,89 \pm 0,38$ & $2,52 \pm 0,30$ & $1,4 \pm 0,17$ & $1,9 \pm 0,30$ \\
\hline Etanol residual (\%) & $76,78 \pm 5,51$ & $67,12 \pm 3,48$ & $78,71 \pm 5,17$ & $74,20 \pm 6,81$ \\
\hline $\operatorname{STD}\left(\mathrm{mg} \mathrm{L}^{-1}\right)$ & $125 \pm 18$ & $224 \pm 38$ & $233 \pm 37$ & $275 \pm 46$ \\
\hline $\mathrm{H}_{2} \mathrm{~S}\left(\mathrm{mg} \mathrm{L}^{-1}\right)$ & $98 \pm 16$ & $171 \pm 30$ & $172 \pm 32$ & $191 \pm 32$ \\
\hline $\mathrm{HS}^{-}\left(\mathrm{mg} \mathrm{L}^{-1}\right)$ & $27 \pm 7$ & $53 \pm 10$ & $60 \pm 8$ & $84 \pm 16$ \\
\hline $\mathrm{AP}\left(\mathrm{mg} \mathrm{CaCO} \mathrm{L}^{-1}\right)$ & $61,37 \pm 4,89$ & $107,05 \pm 26,10$ & $129,1 \pm 45,39$ & $114,22 \pm 26,88$ \\
\hline $\operatorname{AVT}\left(\mathrm{mg} \mathrm{L}^{-1}\right)$ & $933,15 \pm$ & $1487,11 \pm$ & $869,47 \pm$ & $1099,79 \pm$ \\
\hline & 173,03 & 179,90 & 112,15 & 172,43 \\
\hline $\mathrm{pH}_{\mathrm{efl}}$ & $6,03 \pm 0,13$ & $6,09 \pm 0,03$ & $6,15 \pm 0,07$ & $6,25 \pm 0,07$ \\
\hline $\mathrm{SSV}\left(\mathrm{mg} \mathrm{L}^{-1}\right)$ & 20 & 30 & 50 & 31 \\
\hline
\end{tabular}

A fim de reduzir o potencial de geração do sulfeto na etapa de partida, a $\operatorname{CSV}_{\text {afl }}$ foi reduzida para metade $\left(2.000 \mathrm{mg}-\mathrm{SO}_{4}{ }^{2-} \mathrm{L}^{-1}, \mathrm{CSV}=4 \mathrm{kg-SO}{ }_{4}{ }^{2-} \mathrm{m}^{-3} \mathrm{~d}^{-1}\right.$ - etapa II; Tabela 3$)$, de modo que a relação $\mathrm{DQO} / \mathrm{SO}_{4}{ }^{2-}$ sofreu um aumento para 5 (valor teórico). Devido problemas operacionais com a bomba de alimentação, a COV afluente média referente à etapa II esteve em torno de 15,61 e a relação $\mathrm{DQO} / \mathrm{SO}_{4}{ }^{2-}$ média de 4,64. A redução da concentração de sulfato afluente proporcionou condições favoráveis para a melhora da sulfetogênese no sistema, resultando a uma eficiência média de 44,68\% e concentração $224 \mathrm{mg} \mathrm{L}^{-1}$ de sulfeto total dissolvido para essa etapa, superior ao mensurado na etapa I e $\mathrm{CSV}_{\text {rem }}$ de $1,49 \mathrm{~kg}-\mathrm{SO}_{4}{ }^{2-}$ $\mathrm{m}^{-3} \mathrm{~d}^{-1}\left(1,21 \mathrm{~kg}_{-} \mathrm{SO}_{4}{ }^{2-} \mathrm{m}^{-3} \mathrm{~d}^{-1}\right.$ - etapa I) (FIGURAS 16 e 17, Tabela 12), o que evidenciou maior tolerância ao STD. 
FIGURA 16 - Sulfeto estimado ( $\mathrm{H}_{2} \mathrm{~S}+\mathrm{HS}$-) e acumulado na fase líquida de acordo com cada fase operacional do reator acidogênico/sulfetogênico de PU. Nota: Calculo da produção de sulfeto teórico assumindo que $1 \mathrm{~g}$ de $\mathrm{SO}_{4}{ }^{2-}$ reduzido produz $0,33 \mathrm{~g}$ de sulfeto total.

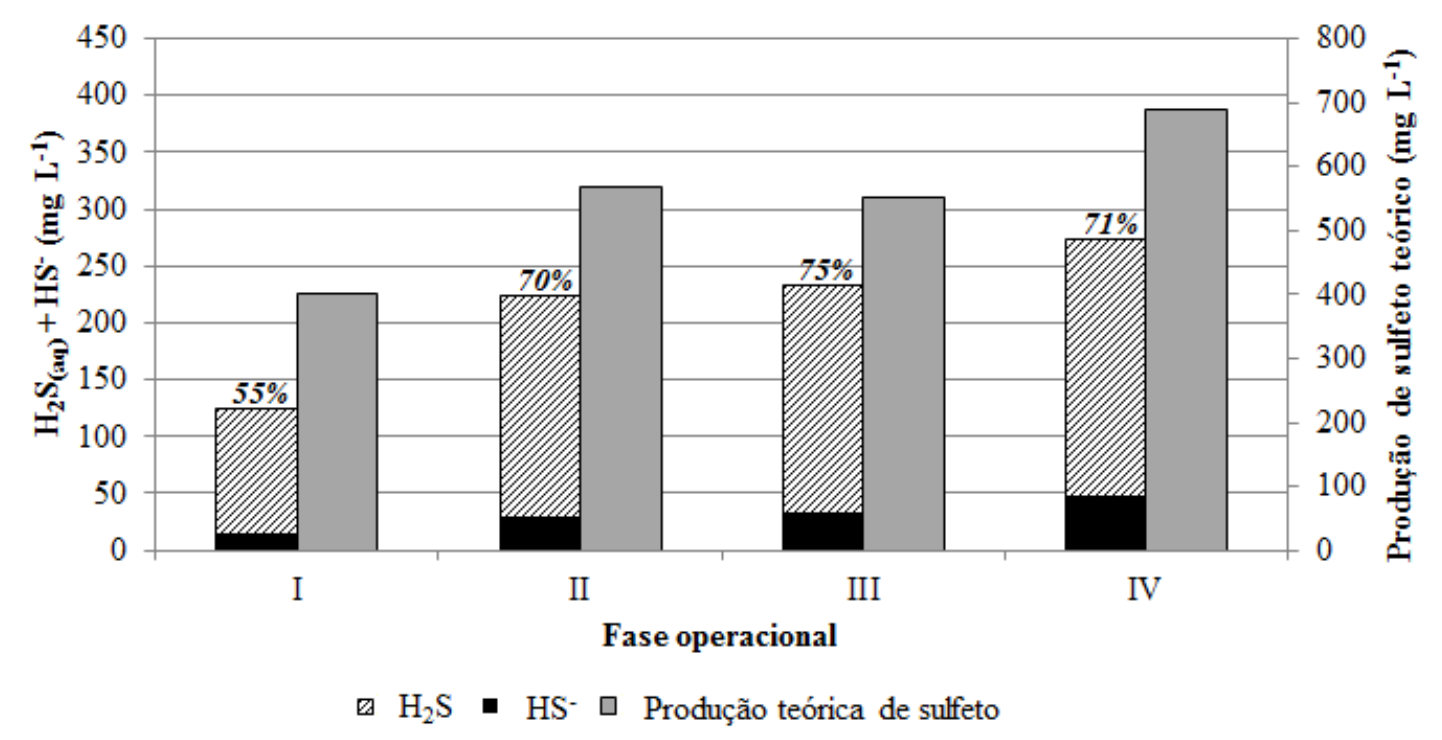

A COV afluente nas etapas II, III e IV se manteve variando no intervalo entre 14,89 e $15,93 \mathrm{~kg}$-DQO $\mathrm{m}^{-3} \mathrm{~d}^{-1}$ (Tabela 12), apresentando redução na eficiência de remoção do sulfato e produção de ácidos orgânicos voláteis durante a etapa III, quando a velocidade ascensional passou para 5,66 $\mathrm{m} \mathrm{h}^{-1}$. A maior turbulência do sistema, devido ao aumento da razão de recirculação, pode ter causado a formação de caminhos preferenciais, já que apesar da concentração de SSV ter sofrido um ligeiro aumento, não resultou em proporções significavas de perda da biomassa ( $50 \mathrm{mg} \mathrm{L}^{-1}$ - fase III, Tabela 12). Durante a fase IV houve aumento na eficiência da CSVrem (46,84\%, Tabela 12), similar ao desempenho da etapa II (44,68\%), quando a velocidade ascensional aplicada esteve em 3,42 $\mathrm{m} \mathrm{h}^{-1}$, em que houve melhora no carga de sulfato removida dede 1,49 (etapa II) para 2,04 (etapa IV), influencianda pelo velocidade ascensional aplicada.

Inicialmente, uma possibilidade para resolver o problema nas fases iniciais do $\mathrm{R}_{\mathrm{AS}}$ PEBD estaria na substituição por um material suporte com maior área superficial, visando maior adesão da biomassa, como a espuma de PU. A aplicação de condições otimizadas no reator de PU (previamente testadas no reator de PEBD) não foram suficientes para garantir uma partida rápida do sistema, sendo identificados outros problemas que provavelmente contribuíram na inibição da sulfetogênese. 
FIGURA 17 - Resultados operacionais referentes ao reator acidogênico/sulfetogênico de PU

(a) Carga orgânica volumétrica removida; (b) Carga de sulfato volumétrica removida; (c) Sulfeto; (d) Ácidos voláteis totais
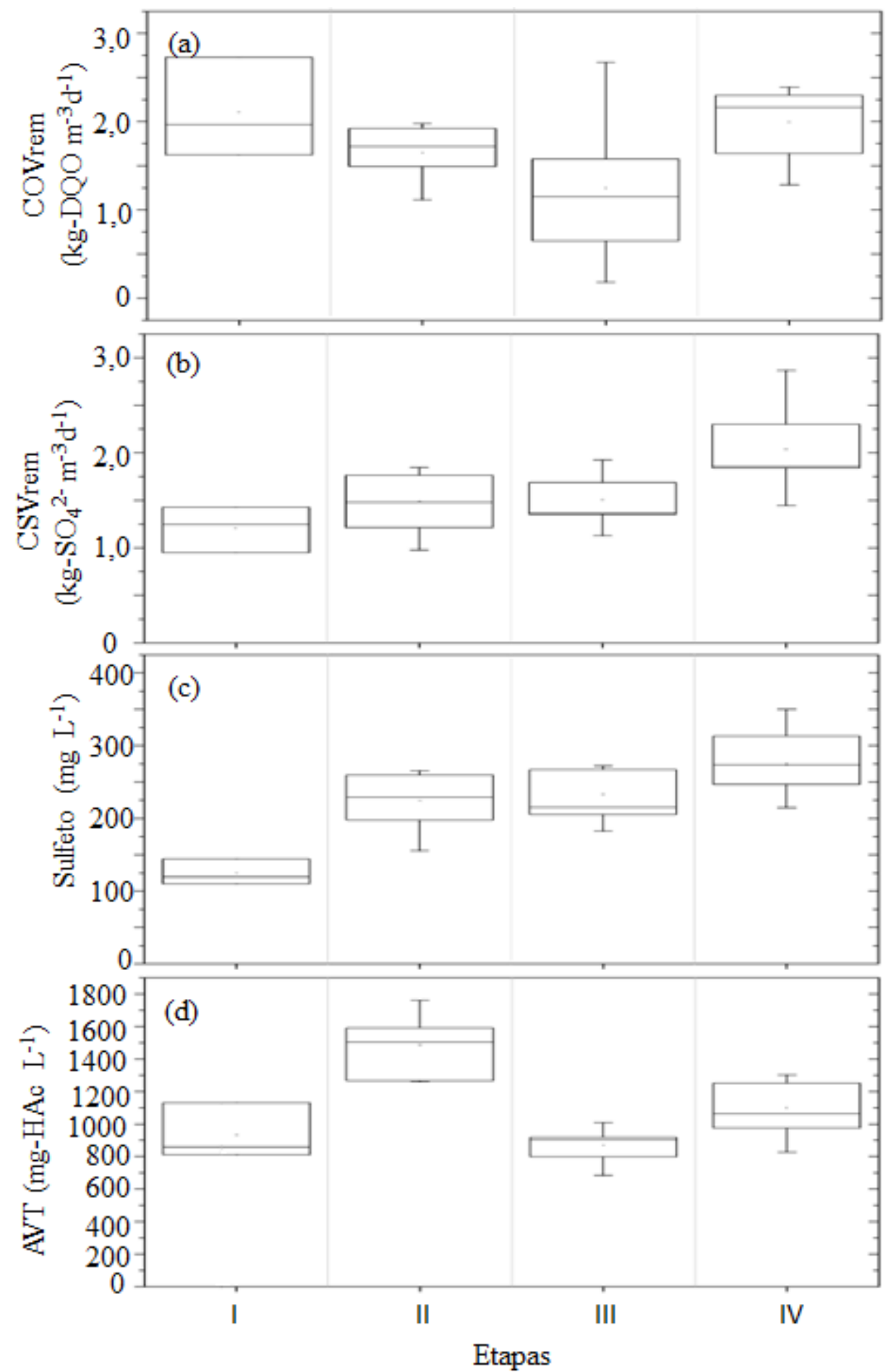

O aumento da velocidade ascensional não acarretou redução significativa na concentração de sulfeto retido no líquido nas fases II-IV (70-75\%, FIGURA 16), sendo que o 
material suporte com elevada área superficial pode não ter facilitado a transferência para a fase gasosa. Van Houten et al., (1994) verificaram que o biofilme formado em material suporte com elevada porosidade (pedra pomes) sofrem baixa influência da turbulência do meio líquido. Esse fato justifica que mesmo com o aumento da velocidade, a proporção de sulfeto retido no líquido não variou devido à baixa influência sobre o material suporte, exercida pela turbulência causada pelo sistema recirculação.

Para vencer a resistência da espuma de PU, velocidades ascensionais acima das testadas poderiam resultar em um aumento no stripping do sulfeto e melhoria na eficiência de remoção do sulfato. Analisando os resultados, mesmo utilizando um material favorável para a retenção de biomassa, a espuma de PU pode ter retido sulfeto no seu interior, ainda quando aplicada maior razão de recirculação que o $\mathrm{R}_{\mathrm{AS} \text {-PEBD }}$ durante as etapas III e IV, inibindo a atividade sulfetogênica. Aquino et al. (2017) relataram que mesmo em reator com produção de biogás rico em metano (facilitador para transferência líquido-gasosa), observou-se o aprisionamento de gás nos interstícios do meio suporte constituído por espuma, o que também

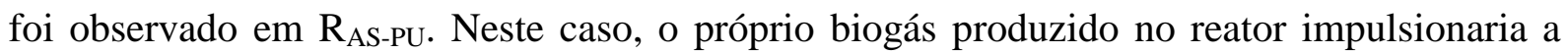
transferência para a fase gasosa (em casos de maior produção de biogás). Fuess et al. (2017c) descrevem limitação na transferência de massa devido ao acúmulo excessiva de biomassa em reator UASB, o que também pode ter ocorrido no $\mathrm{R}_{\mathrm{AS}-\mathrm{PU}}$, já que a espuma apresenta elevada área superficial e o material possuir características que permitem a deformação da espuma nas paredes do reator, obstruindo facilmente o leito, aumentando a perda de carga no escoamento (líquido e gás). $\mathrm{O} \quad \mathrm{R}_{\mathrm{AS}-\mathrm{PU}}$ apresentou uma baixa produção de biogás, sendo predominantemente constituído por sulfeto em sua composição, consistindo em um fator desfavorável para a transferência fase líquida-gasosa. Outro fator que poder ter influenciado, assim como no $\mathrm{R}_{\mathrm{AS}-\mathrm{PEBD}}$, foi a utilização de lodo predominantemente metanogênico como inóculo, já que ao final da operação o reator acidogênico/sulfetogênico de PU continha 1,6 vezes mais biomassa aderida que o PEBD (12.130 $\mathrm{mg}$ em $\mathrm{R}_{\mathrm{ASI}}$ e $19.461 \mathrm{mg}$ em $\left.\mathrm{R}_{\mathrm{ASII}}\right)$. De acordo com os resultados obtidos ao logo de todo o período de monitoramento de ambos os reatores, uma possibilidade é que o lodo demanda de um longo período de adaptação e produção de uma biomassa com maior concentração bactérias sulfetogênica, o que justifica a baixa remoção de sulfato após utilizar um material suporte com maior área superficial, além do crescimento das BRS em etanol apresenta menor taxa de crescimento (Cao et al., 2012).

A composição do biogás permaneceu com o $\mathrm{H}_{2} \mathrm{~S}$ predominando em todas as etapas operacionais do $\mathrm{R}_{\mathrm{AS}-\mathrm{PU}}$. No entanto, o aparecimento de metano (aproximadamente $6 \%$ ) se deu 
apenas na etapa IV, quando o $\mathrm{pH}$ manteve um valor médio de 6,25, superior ao das etapas anteriores. A mudança na composição do biogás provavelmente está associada ao pH, já que o sulfeto que seria um fator inibitório às metanogênicas também apresentou aumento na concentração de $233 \mathrm{mg} \mathrm{L}^{-1}$ (etapa III) para $275 \mathrm{mg} \mathrm{L}^{-1}$ (etapa IV) nesta etapa.

FIGURA 18 - Composição do biogás produzido no reator acidogênico/sulfetogênico com poliuretano como material suporte $\left(\mathrm{R}_{\mathrm{AS}-\mathrm{PU}}\right)$

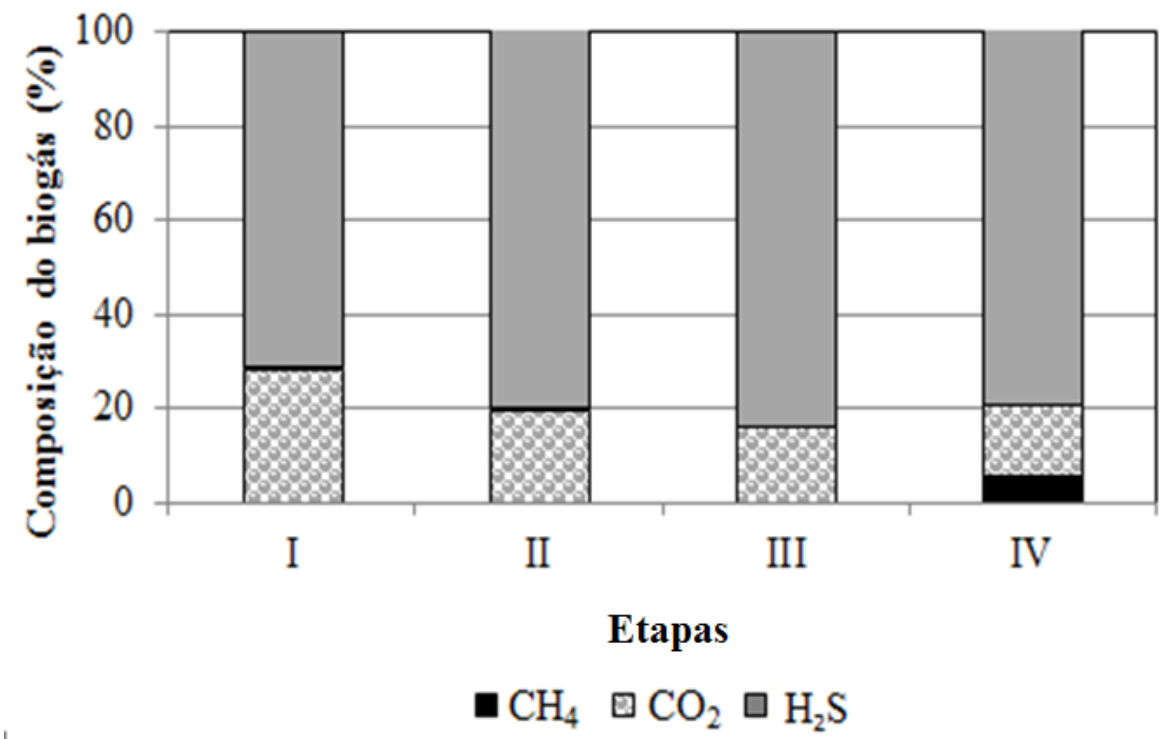

$\mathrm{Na}$ última etapa houve redução na proporção de sulfeto retido no meio líquido, possivelmente influenciado pelo aumento na razão de recirculação e produção de metano gerando maior turbulência da fase líquida, resultando em maior stripping do $\mathrm{H}_{2} \mathrm{~S}$ e melhor homogeneização do meio, provocando aumento do $\mathrm{pH}$, assim como observado no $\mathrm{R}_{\mathrm{AS} \text {-PEBD }}$.

De acordo com os parâmetros de monitoramento, a maior limitação do sistema está associada ao inóculo utilizado para partida do reator. A aplicação de um lodo metanogênico dificultou no estabelecimento de um sistema sulfetogênico até que a biomassa fosse fortemente atuante como redutora de sulfato.

Ao desmontar o reator, observou-se uma formação excessiva de biomassa na espuma e entre elas, como mostrado na FIGURA 19.

$\mathrm{O}$ estado de colmatação ao final da operação do $\mathrm{R}_{\mathrm{AS} \text {-PU }}$ sugere que mesmo aplicando velocidade ascensional de aproximadamente $8 \mathrm{~m} \mathrm{~h}^{-1}$, o sistema não apresentou significativa perda de sólidos, o que resultou no acúmulo de biomassa no leito constituído por espuma de PU. Com a colmatação, houve uma redução da área no interior do reator, o que diminui o 
volume ativo do reator e TDH, resultando em velocidade ascensional maior que a calculada e ajustada através da vazão de recirculação (Escudié, Cresson, Delgenès, \& Bernet, 2011). Se o aumento da velocidade ascensional estivesse distribuído igualmente pelo reator, seria observada maior perda de sólidos e menor acúmulo entre os cubos no leito ao final da operação. Esse fato, juntamente com a baixa eficiência ao longo do monitoramento das quatro etapas operacionais, sugerem a formação de caminhos preferenciais.

FIGURA 19 - Composição do leito estruturado composto por cubos de espuma de poliuretano do reator acidogênico/sulfetogênico $\left(\mathrm{R}_{\mathrm{AS}-\mathrm{PU}}\right)$ ao final da operação das quatro etapas

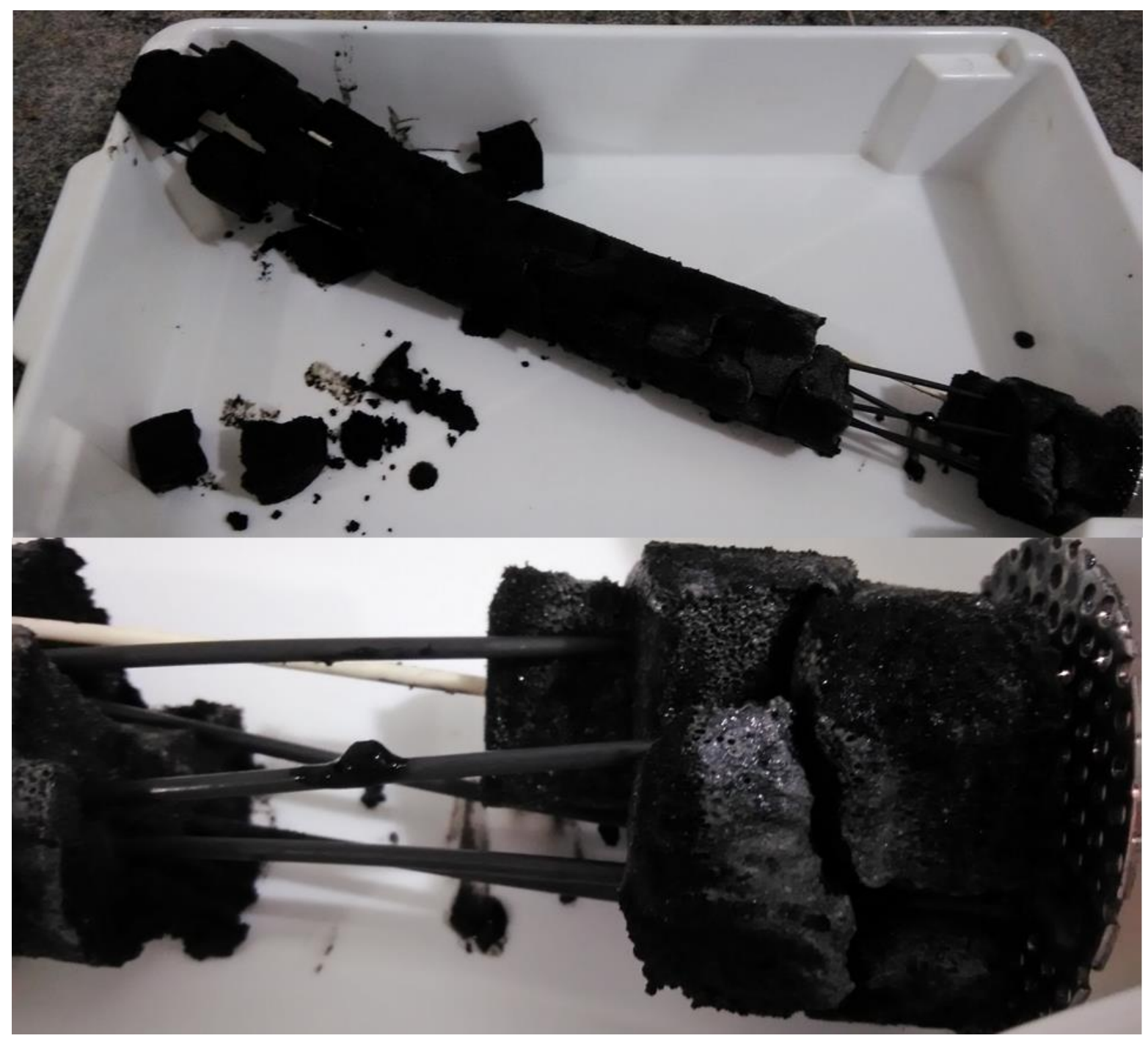




\subsection{Considerações finais sobre os reatores acidogênicos/sulfetogênico primeira fase $\left(\mathbf{R}_{\mathrm{AS}}\right.$ -} PEBD $\mathbf{e} \mathbf{R}_{\text {AS-PU }}$

Esse trabalho visou explorar o comportamento, influências, efeitos positivos e negativos de um sistema com separação de fases, sendo o foco promover a redução do sulfato durante a primeira fase do tratamento.

Verificou-se que o sistema apresentou diversos problemas operacionais, principalmente nas etapas iniciais. Entretanto as dificuldades no estabelecimento de um sistema redutor de sulfato foram superadas.

Apesar do sucesso na aplicação de lodos metanogênicos em reatores sulfetogênico/metanogênico em diversos trabalhos encontrados na literatura (citados anteriormente), observou-se que a adaptação da biomassa sob condição termofílica, reduzido $\mathrm{TDH}$ (menor que os trabalhos anteriormente executados) e pH ligeiramente ácido demandou de um longo tempo até que os microrganismos estivessem ambientados às condições impostas. A partida de sistemas termofílico pode demandar de um longo período, havendo relatos com mais de um ano para pleno estabelecimento biológico (Escudié, Cresson, Delgenès, \& Bernet, 2011). Além das dificuldades na partida sob condição termofílica, somou-se a esse trabalho a utilização de lodo com biomassa rica em microrganismos metanogênicos, o que necessitou de um período para desenvolvimento de uma biomassa sulfetogênica.

A recirculação foi de extrema importância para redução da toxicidade provocada pelo sulfeto na forma não dissociada e aumento da mistura e transferência de massa, resultando na redução do gradiente de $\mathrm{pH}$ ao longo da altura do reator, principalmente no reator com PEBD $\left(\mathrm{R}_{\mathrm{AS}-\mathrm{PEBD}}\right)$, no qual a reduzida área superficial não demandou de velocidades ascensionais tão elevadas como o reator com PU ( $\left.\mathrm{R}_{\mathrm{AS}-\mathrm{PU}}\right)$ para alcançar o propósito de transferir o sulfeto para fase gasosa.

A utilização da espuma de PU como material suporte causou problemas com colmatação do leito e formação de caminhos preferenciais, o que resultou em eficiência de remoção do sulfato aquém da alcançada com os cilindros de PEBD. A adoção de estratégias para redução de colmatação possivelmente teria melhorado as condições de partida do reator, havendo a possibilidade de uma partida mais rápida que o $\mathrm{R}_{\mathrm{AS} \text {-PEBD }}$. Alguns sistemas utilizam o próprio biogás gerado no processo anaeróbio para o desprendimento do excesso de 
biomassa e sua manutenção (Escudié et al., 2011). No entanto, esse mecanismo pode ser utilizado apenas em sistemas com produção de volume considerado de biogás, de modo que possibilite sua transferência da fase gasosa, sem que permaneça preso entre o material suporte e a biomassa.

\subsection{Reatores metanogênico de segunda fase e fase única}

As etapas operacionais dos reatores metanogênico consistiram em avaliar a partida de dois reatores metanogênicos, sendo um de segunda fase $\left(R_{M I}\right)$ e outro de fase única $\left(R_{M I I}\right)$.

A aplicação da água residuária nos reatores metanogênicos consistiu em escolher a condição operacional da subetapa $X$ do reator acidogênico/sulfetogênico de primeira fase $R_{A S}$ PEBD, cuja concentração residual de sulfato no efluente apresentou menor porcentagem (valor médio de 6,7\% de CSV residual; Tabela 11), de modo a comparar os desempenhos dos reatores submetidos à separação de fases com reator fase única. A descrição sobre a composição da água residuária sintética está expressa nas Tabelas 9 e 10.

Os reatores metanogênicos tiveram a mesma estratégia operacional na partida, com carga orgânica de $2,5 \mathrm{~g} \mathrm{~d}^{-1}$ para ambos os reatores. A água residuária de $\mathrm{R}_{\mathrm{MI}}$ continha etanol e ácido acético como fontes de carbono, de acordo com as características do efluente final da subetapa $\mathrm{X}$ de $\mathrm{R}_{\mathrm{AS} \text {-PEBD. }}$ A operação desses reatores visava promover o aumento gradativo da carga orgânica até atingir $5 \mathrm{~g} \mathrm{~d}^{-1}$. Dessa forma, caracterizaram-se como etapa de partida as condições operacionais anteriores a essa carga, cujo parâmetro de monitoramento utilizado foi a remoção de DQO e composição do biogás.

O estágio inicial do reator de fase única (com CO de 2,5 $\mathrm{g} \mathrm{d}^{-1}$ ) apresentou remoção da matéria orgânica inferior a 40\%, de forma que se adotou como estratégia a redução da carga orgânica para $0,625 \mathrm{~g} \mathrm{~d}^{-1}$, com partida mais lenta e aumento gradativo da carga orgânica para não causar estresse no meio e/ou colapso do sistema. Já o reator metanogênico de segunda fase atingiu nesse mesmo estágio, remoção de matéria orgânica acima de $85 \%$, o que permitiu o aumento da carga orgânica para 3,5 $\mathrm{g} \mathrm{d}^{-1}$. Com remoção média de $97 \%$, a carga passou para $5 \mathrm{~g} \mathrm{~d}^{-1}$ na etapa final de operação.

Para a etapa inicial, o reator metanogênico de segunda fase (primeiros 42 dias) apresentou uma eficiência superior a $78 \%$ na produção de metano, quando comparado ao sistema de fase única (38 dias de operação) $\left(\mathrm{CO}=2,5 \mathrm{~g} \mathrm{~d}^{-1}\right.$; FIGURA 20). 
FIGURA 20 - Comparação entre a produção diária de metano (boxplot) entre os reatores de segunda fase $\left(\mathrm{R}_{\mathrm{MI}}\right)$ e fase única $\left(\mathrm{R}_{\mathrm{MII}}\right)$ relacionada com a carga orgânica (- - -)

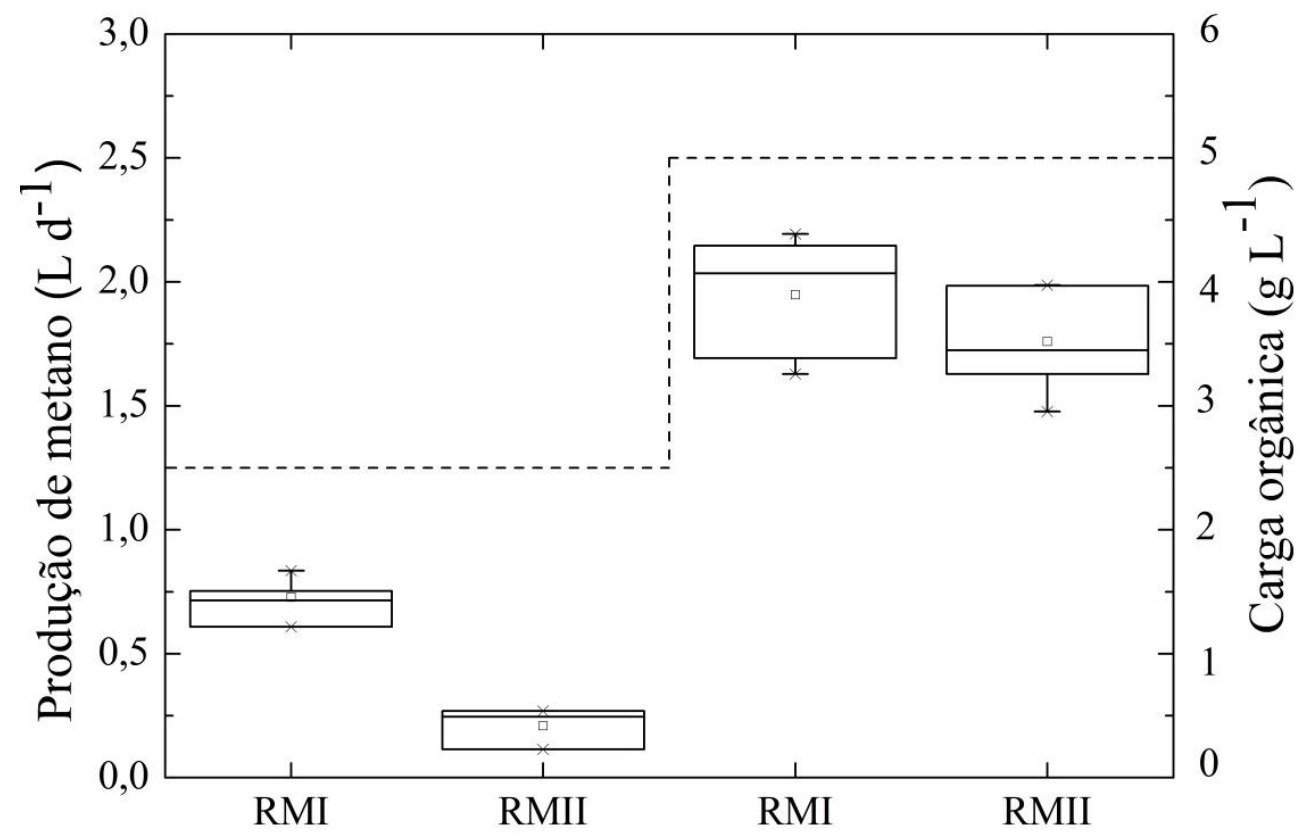

O reator de segunda fase provavelmente foi influenciado positivamente pela baixa concentração de sulfato na composição da água residuária, o qual resultou em $5 \mathrm{mg} \mathrm{L}^{-1}$ de sulfeto no efluente durante a etapa com carga orgânica de $5 \mathrm{~g} \mathrm{~d}^{-1}$. Nesse estágio de operação, o reator de fase única continha $400 \mathrm{mg}$ de $\mathrm{SO}_{4}{ }^{2-} \mathrm{L}^{-1}$ (Tabela 5), o que resultou na maior dificuldade de estabelecimento do processo, o que implicou na concentração média de $93 \mathrm{mg}$ $\mathrm{L}^{-1}$ de sulfeto no efluente de $\mathrm{R}_{\mathrm{MII}}$ (produção teórica de aproximadamente $133 \mathrm{mg}$ de $\mathrm{H}_{2} \mathrm{~S} \mathrm{~L}^{-1}$ contra $8 \mathrm{mg}$ de $\mathrm{mg} \mathrm{de} \mathrm{H}_{2} \mathrm{~S} \mathrm{~L}^{-1}$ no reator de segunda fase). Segundo Parkin et al. (1990), níveis de sulfeto entre 50 e $200 \mathrm{mg} \mathrm{L}^{-1}$ já são suficientes para inibir a geração de metano, de forma que as metanogênicas são mais prejudicadas que outros grupos, como as BRS.

O período inicial de partida do reator de segunda fase atingiu remoção de COV em torno de $87 \%\left(\mathrm{CO}_{\mathrm{afl}}=2,5 \mathrm{~g} \mathrm{~d}^{-1}\right)$, de modo que a remoção da matéria orgânica sofreu insignificante influência da sulfetogênese. A remoção de DQO na fase inicial pela via sulfetogênica correspondeu a uma concentração de aproximadamente $16 \mathrm{mg} \mathrm{L}^{-1}(\mathrm{COV}=0,03$ kg-DQO $\mathrm{m}^{-3} \mathrm{~d}^{-1}$, equivalente a uma geração teórica de aproximadamente de $5 \mathrm{mg} \mathrm{L}^{-1}$ de sulfeto).

Para a mesma condição e período operacional, $\mathrm{R}_{\mathrm{MII}}$ obteve uma eficiência de remoção total de COV em torno de 42,77\%. Essa fração removida engloba a matéria orgânica

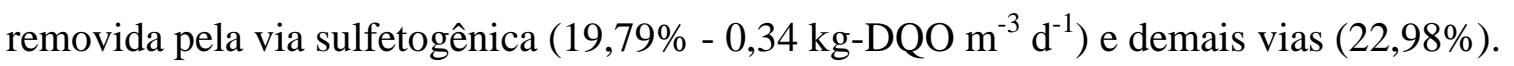


No reator de fase única, o sulfato também teve sua concentração reduzida de 400 para

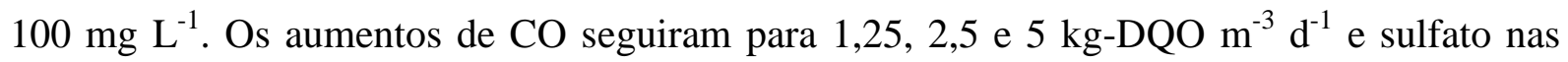
proporções $200 \mathrm{mg} \mathrm{L}^{-1}$ nas três cargas e posteriormente $400 \mathrm{mg} \mathrm{L}^{-1}$ apenas para a carga de 5 $\mathrm{kg}$-DQO $\mathrm{m}^{-3} \mathrm{~d}^{-1}$. O aumento da concentração do sulfato não foi mantido proporcional à alteração da carga orgânica, a fim de reduzir os impactos causados pelo sulfeto na etapa de estabilização. Após a redução da carga para 0,625 kg-DQO $\mathrm{m}^{-3} \mathrm{~d}^{-1}$, o sistema primeiramente foi adaptado ao aumento de carga orgânica, para posteriormente ser submetido aos efeitos do sulfeto no sistema.

A composição do biogás variou entre os dois reatores e devido a problemas com técnicos com o medidor de vazão no período de operação, os cálculos de geração do metano levaram em consideração a DQO removida e a produção teórica de metano a $55^{\circ} \mathrm{C}(0,420 \mathrm{~L}$ $\mathrm{CH}_{4} \mathrm{~g}^{-1} \mathrm{DQO}_{\text {rem }}$ ). A FIGURA 21 representa a média da composição do biogás dos reatores metanogênico operados submetidos à carga orgânica de $5 \mathrm{~g} \mathrm{~d}^{-1}$. O reator de segunda fase demandou 75 dias até atingir etapa com essa carga orgânica, enquanto o reator de fase única necessitou de 119 dias.

Observa-se que a presença de metano esteve acima de $82 \%$ em $\mathrm{R}_{\mathrm{MI}}$ e $\mathrm{H}_{2} \mathrm{~S}$ abaixo do limite de detecção. Enquanto para a mesma condição em $\mathrm{R}_{\mathrm{MII}}$, a proporção de metano representa 77,52\% da composição total do biogás, $20,90 \%$ de $\mathrm{CO}_{2}$ e 1,57\% de sulfeto. Em comparação entre dois sistemas operados com melaço como fonte de carbono, Pender et al. (2004) verificou reduzida porcentagem de metano no biogás em sistema contendo sulfato, com valor em torno de $25 \%$ e apenas $45 \%$ na remoção de DQO. No entanto, esse sistema contava com uma concentração afluente de aproximadamente $3.000 \mathrm{mg} \mathrm{L}^{-1}$ de $\mathrm{SO}_{4}{ }^{2-}$, o que implicou em uma concentração de sulfeto mais elevada no efluente e maior potencial tóxico.

Em $\mathrm{R}_{\mathrm{MII}}$, a porcentagem de $\mathrm{CO}_{2}(17,20 \%)$ apresentou-se superior que $\mathrm{R}_{\mathrm{MI}}$ por influência da sulfetogênese, onde há geração de alcalinidade no processo de redução do sulfato a sulfeto. Outro fator que contribuiu foi a etapa de acidogênese no reator de fase única, com produção de $\mathrm{H}_{2}$ e $\mathrm{CO}_{2}$, o que pode ser verificado pela maior concentração AVT em $\mathrm{R}_{\mathrm{MII}}$ durante a operação com CO $5 \mathrm{~g} \mathrm{~d}^{-1}\left(\mathrm{AVT}=42,74 \mathrm{mg} \mathrm{L}^{-1}-\mathrm{R}_{\mathrm{MI}}\right.$ e 82,25 $\mathrm{mg} \mathrm{L}^{-1}=\mathrm{R}_{\mathrm{MII}}$, Tabela 13). Essa etapa ocorre em menor intensidade no reator de segunda fase, já que uma parcela da carga orgânica encontrava-se na forma de ácido acético (resultante da conversão no reator de primeira fase), prontamente disponível às metanogênicas. 
FIGURA 21 - Composição do biogás nos reatores metanogênicos de segunda fase (RMI) de fase única (RMII) durante a operação com carga orgânica de $5 \mathrm{~g} \mathrm{~d}^{-1}$

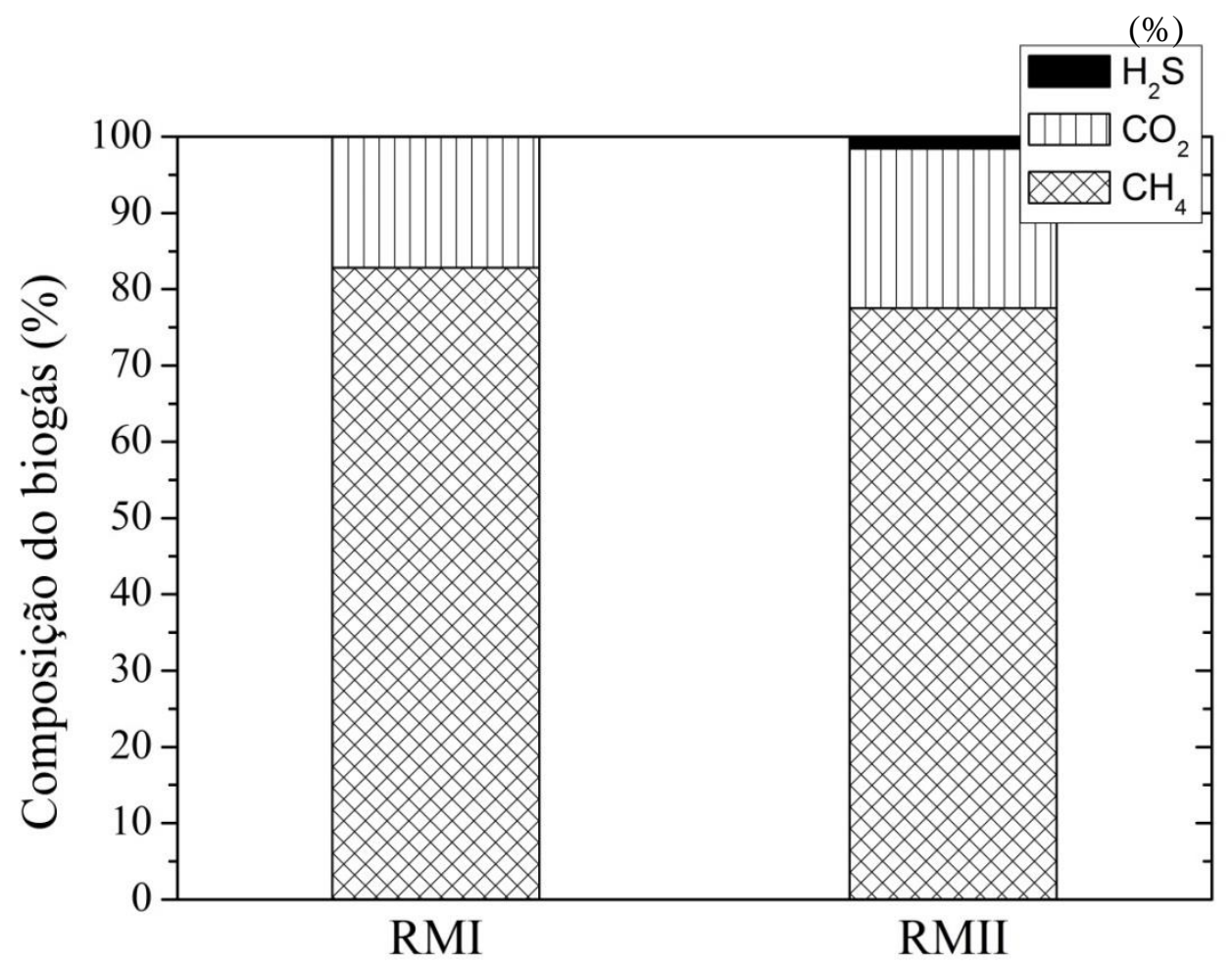

Tabela 13 - Desempenho global dos reatores metanogênico de segunda fase $\left(R_{M I}\right)$ e fase única $\left(\mathrm{R}_{\mathrm{MII}}\right)$ submetidos à carga orgânica de $5 \mathrm{~g} \mathrm{~d}^{-1}$

\begin{tabular}{lcc}
\hline Variável-resposta & $\mathrm{R}_{\mathrm{MI}}$ & $\mathrm{R}_{\mathrm{MII}}$ \\
\hline $\mathrm{ER}_{\mathrm{DQO}}(\%)$ & $98,76 \pm 0,67$ & $95,09 \pm 2,35$ \\
$\mathrm{COV}_{\mathrm{afl}}\left(\mathrm{kg} \mathrm{m}^{-3} \mathrm{~d}^{-1}\right)$ & $5,02 \pm 0,38$ & $4,03 \pm 0,53$ \\
$\mathrm{CSV}_{\mathrm{afl}}\left(\mathrm{kg} \mathrm{m}^{-3} \mathrm{~d}^{-1}\right)$ & $-*$ & $0,63 \pm 0,09$ \\
$\mathrm{STD}\left(\mathrm{mg} \mathrm{L}^{-1}\right)$ & $5,10 \pm 0,82$ & $92,96 \pm 11,47$ \\
$\mathrm{AP}\left(\mathrm{mg} \mathrm{CaCO}^{-1}\right)$ & $1303,87 \pm 87,06$ & $1314,75 \pm 153,67$ \\
$\mathrm{AVT}\left(\mathrm{mg} \mathrm{L}^{-1}\right)$ & $42,74 \pm 22,22$ & $82,25 \pm 4,90$ \\
$\mathrm{pH}$ & $7,72 \pm 0,09$ & $7,80 \pm 0,13$ \\
Produção de $\mathrm{CH}_{4}\left(\mathrm{~L} \mathrm{de} \mathrm{CH}_{4} \mathrm{~d}^{-1}\right)$ & $1,95 \pm 0,23$ & $1,76 \pm 0,22$
\end{tabular}

*Devido à baixa concentração de sulfato no reator $\mathrm{R}_{\mathrm{MI}}$, esse parâmetro não foi levado em consideração no monitoramento.

No último estágio de operação, entre os dias 84 e 102 em $R_{M I}$ e 128 e 140 para $R_{\text {MII }}$ o reator de segunda fase apresentou uma produção de metano diária 9,74\% superior. Mesmo após 120 dias de operação (período superior de operação que $\mathrm{R}_{\mathrm{MI}}$ ), o reator de fase única não alcançou melhor eficiência na produção de metano, comparado com $\mathrm{R}_{\mathrm{MI}}$. Viñas et al. (1993) conseguiu promover o start up em sistema com separação de fases em 12 semanas (COV = 11 
$\mathrm{kg}$-DQO $\mathrm{m}^{-3} \mathrm{~d}^{-1} \mathrm{e}^{\mathrm{e}} \mathrm{DQO}$ rem $=95 \%$ ), enquanto os outros dois sistemas foram de fase única, o que demandou de 30 semanas para o reator inoculado com lodo de lagoa (COV $=7 \mathrm{~kg}-\mathrm{DQO} \mathrm{m} \mathrm{m}^{-3}$ $\left.1, \mathrm{DQO}_{\mathrm{rem}}=65 \%\right)$ e 50 semanas para biorreator com lodo de digestor rural $(\mathrm{COV}=7 \mathrm{~kg}$ DQO $\mathrm{m}^{-3} \mathrm{~d}^{-1}, 75 \%$ DQO removida) e inibição da atividade metanogênica devido a concentração de ácidos. Esses dados corroboram com o desempenho dos reatores $\mathrm{R}_{\mathrm{MI}}$ e $\mathrm{R}_{\mathrm{MII}}$, em que além da separação de fases reduz o período de partida, ainda apresenta maior eficiência de tratamento e carga orgânica volumétrica aplicada.

Os resultados de desempenhos dos reatores metanogênicos mostraram eficiência superior em sistema com separação de fase, o que é uma vantagem no ponto de vista ambiental. No sistema de duas fases, há separação de um gás altamente nocivo do biogás $\left(\mathrm{H}_{2} \mathrm{~S}\right)$ no reator de primeira fase, com maior produção de metano com potencial energético. A separação de fases permitiu partida mais rápida do reator metanogênico de sistema de duas fases, como relatado na literatura sobre a maior estabilidade desse tipo de sistema, capaz de suportar aumento de carga orgânica (Luo et al., 2011), superior rendimento de metano e biodegradabilidade de substrato (Ferraz Jr. et al., 2016).

O estudo não focou na variação da dosagem de agente tamponante (bicarbonato de sódio), porém esse é outro fator importante para a redução de custo em sistema de duas fases tratando água residuária contendo compostos oxidados de enxofre, em que ocorre a geração de alcalinidade pela produção de sulfeto, o que reduz a necessidade de álcali para o reator de segunda fase. Ferraz Jr. et al. (2016) comparou dois sistemas em reatores UASB, aplicando vinhaça de cana de açúcar, atingindo maior remoção da DQO solúvel, rendimento de metano, com adição de 6,25 g de bicarbonato de sódio $\mathrm{L}^{-1}$ em sistema de duas fases. Posteriormente, Fuess et al. (2017c) testou a adição de uma concentração de $3,0 \mathrm{~g} \mathrm{~L}^{-1}$ de bicarbonato de sódio (0,13 g de bicarbonato por g DQO),o que resultou na redução da matéria orgânica removida, recuperando a eficiência com a aplicação de 6,25 g L-1 (aproximadamente 0,3 g de bicarbonato por g de DQO . A separação de fases durante o tratamento de uma água residuária rica em sulfato tem a vantagem da geração de alcalinidade durante a via de redução do sulfato. Assim, os resultados do presente estudo fornecem subsídios para o desenvolvimento de futuras tecnologias com redução de custos com tratamento de uma água residuária real, aliando uma rota metabólica produtora de agente tampão e a separação de fases. 


\section{CONSIDERAÇÕES FINAIS}

O presente trabalho visou explorar a separação de fases na digestão anaeróbia, aplicando água residuária com elevada concentração de sulfato e sob condições termofílica.

Durante a execução da pesquisa, constatou-se a dificuldade na adaptação da biomassa inicialmente metanogênica, exposta a efluente com compostos de enxofre (lodo da usina sucroalcooleira e de abatedouro de aves), utilizada como inóculo para reatores sulfetogênico.

As dificuldades encontradas estiveram associadas a:

- Exposição à elevada temperatura, selecionando microrganismos tolerantes a esta condição;

- Utilização de uma biomassa predominantemente metanogênica, o que demandou maior tempo para o estabelecimento da população de bactérias responsáveis pela redução do sulfato;

- Geração de um gradiente de pH e sulfeto ao longo da altura do reator;

- Concentrações de sulfeto que podem ter causado inibição do processo durante a adaptação dos microrganismos às condições acidogênicas/sulfetogênica.

No entanto, algumas estratégias operacionais apresentaram resultados positivos no processo, como o aumento da velocidade ascensional através do sistema de recirculação. A maior agitação do meio resultou na redução do gradiente de $\mathrm{pH}$ e sulfeto, promovendo o stripping de parcela do sulfeto e reduzindo o efeito tóxico na fase líquida, reinserção de alcalinidade através da recirculação do efluente no reator, enriquecimento da biomassa com a mistura de lodos.

Após período de operação e adoção de estratégias operacionais de sucesso no reator $\mathrm{R}_{\mathrm{AS}-\mathrm{PEBD}}$, levantou-se a hipótese do longo período de partida ser reduzido utilizando um material suporte com maior área superficial, como a espuma de PU. No entanto, foram enfrentados outros problemas na operação do $\mathrm{R}_{\mathrm{AS}-\mathrm{PU}}$. Mesmo aplicando as estratégias de sucesso do $\mathrm{R}_{\mathrm{AS}-\mathrm{PEBD}}$, o $\mathrm{R}_{\mathrm{AS}-\mathrm{PU}}$ apresentou partida lenta e eficiência de remoção abaixo do alcançado no outro reator.

Verificou-se que os problemas de baixo rendimento no $\mathrm{R}_{\mathrm{AS}-\mathrm{PU}}$ poderiam estar relacionados ao excesso de biomassa no leito, o que gerou colmatação e aparecimento de caminhos preferenciais. Os caminhos preferenciais reduzem o TDH do reator e o contanto 
com a biomassa. Outra estratégica de disposição da espuma de PU poderia reduzir esses problemas, aumentando a transferência de massa efluente/biomassa.

Quanto à geração de metano, assim como alguns relatos da literatura, o sistema de duas fases apresentou desempenho superior, com maior eficiência de remoção de matéria orgânica e produção de metano. Já o sistema de fase única necessitou de maior tempo de partida, além de sofrer com os efeitos do sulfeto, tanto na adaptação da biomassa, como na remoção de matéria orgânica e geração de biogás.

Apesar das dificuldades com adaptação dos reatores acidogênicos/sulfetogênico, foi possível testar a separação de fases com a vertente acidogênico/sulfetogênico - metanogênico, de modo que o processo pode se tornar uma alternativa aos processos biotecnológicos, visando a geração de efluente ambientalmente adequado, reduzindo a concentração de compostos ainda com potencial de causar danos (como o sulfeto), além de produzir um biogás rico em metano com reduzida ou ausência de sulfeto, o que viabiliza sua aplicação e redução de custos com tratamentos do biogás.

O sulfeto transferido para a fase gasosa no reator de primeira fase pode ser aplicado em outros processos, como a desnitrificação autotrófica ou até mesmo a produção de enxofre elementar, dando um destino com aplicação secundária e biotecnologicamente interessante, já que utiliza um efluente gasoso do processo como doador de elétrons em outro. 


\section{CONCLUSÕES}

Baseando-se nos principais objetivos do presente trabalho e resultados obtidos ao longo da operação dos reatores anaeróbios:

- A redução do sulfato ocorreu em reator de primeira fase (acidogênico/sulfetogênico), sob à temperatura de $55^{\circ} \mathrm{C}$, sem atividade metanogênica;

- A baixa relação DQO/sulfato favoreceu o fluxo de elétrons para o processo sulfetogênico, sendo que o aumento da concentração de sulfato na etapa inicial do reator acidogênico/sulfetogênico com suporte de polietileno de baixa densidade resultou em melhoria da carga de sulfato removida. No entanto, manter apenas a baixa relação DQO/sulfato não foi suficiente para promover a partida do reator acidogênico/sulfetogênico de primeira fase;

- O aumento da velocidade ascensional por meio da recirculação do efluente promoveu o stripping de uma parcela do sulfeto, reduziu os efeitos negativos da formação de gradiente de $\mathrm{pH}$ e sulfeto e reinseriu alcalinidade ao reator, o que favoreceu um aumento na carga de sulfato removida e produção de AVT, tendo ácido acético como único ácido detectado;

- A aplicação da espuma de poliuretano resultou em maior adesão da biomassa que o polietileno de baixa densidade. Porém, o excesso de biomassa causou colmatação do leito e surgimento de caminhos preferenciais, resultando em menor eficiência na remoção do sulfato que o reator com PEBD;

- A separação de fases promoveu a geração de um efluente com reduzida porcentagem de sulfato residual no efluente do reator de primeira fase e maior produção de metano no reator de segunda fase, comparado ao sistema único. O sistema único sofreu com os efeitos do sulfeto, apresentando partida mais lenta e com reduzidas cargas orgânica que o reator de segunda fase. 


\section{SUGESTÃO PARA TRABALHOS FUTUROS}

Durante a realização do presente trabalho, foram identificados alguns problemas operacionais e lacunas na literatura que poderiam ser exploradas em pesquisas futuras.

- Utilização de sedimento marinho como inóculo de sistema acidogênico/sulfetogênico e/ou pré aclimatação desta biomassa com substrato específico para comunidade redutora de sulfato;

- Confecção de reator com espuma de poliuretano com disposição do material suporte de forma que dificulte a colmatação do leito em um reator acidogênico/sulfetogênico;

- Aplicação de água residuária real (como a vinhaça) em sistema de separação de fases em sistema de duas fases;

- Aplicação do sulfeto gerado no reator de primeira fase em sistema de remoção de nitrogênio por processo de desnitrificação autotrófica. 


\section{REFERÊNCIAS}

Adorno, M. A. T., Hirasawa, J. S., \& Varesche, M. B. A. (2014). Development and Validation of Two Methods to Quantify Volatile Acids (C2-C6) by GC/FID: Headspace (Automatic and Manual) and Liquid-Liquid Extraction (LLE). American Journal of Analytical Chemistry, 05(07), 406-414. https://doi.org/10.4236/ajac.2014.57049

Amani, T., Nosrati, M., Mousavi, S. M., \& Elyasi, S. (2015). Study of microbiological and operational parameters in thermophilic syntrophic degradation of volatile fatty acids in an upflow anaerobic sludge blanket reactor. Journal of Environmental Chemical Engineering, 3(1), 507-514. https://doi.org/10.1016/j.jece.2014.12.016

Ansari, A., Bagreev, A., \& Bandosz, T. J. (2005). Effect of adsorbent composition on H2S removal on sewage sludge-based materials enriched with carbonaceous phase. Carbon, 43(5), 1039-1048. https://doi.org/10.1016/j.carbon.2004.11.042

Anzola-Rojas, M. del P., Zaiat, M., \& De Wever, H. (2016). Improvement of hydrogen production via ethanol-type fermentation in an anaerobic down-flow structured bed $\begin{array}{llll}\text { reactor. } & \text { Bioresource } & \text { Technology, } & \text { 202, }\end{array}$ https://doi.org/10.1016/j.biortech.2015.11.084

Anzolas-Rojas, M. del P. (2014). Estratégia para a produção contínua de hidrogênio em reator anaeróbio de leito fixo. Universidade de São Paulo.

APHA/AWWA/WEF. (2005). Standard methods for the examination of water and wastewater. (APHA, Ed.) (21st ed.). Washington D.C.

Aquino, S. de, Fuess, L. T., \& Pires, E. C. (2017). Media arrangement impacts cell growth in anaerobic fixed-bed reactors treating sugarcane vinasse: structured vs. randomic biomass immobilization. Bioresource Technology, 235, 219-228. https://doi.org/10.1016/j.biortech.2017.03.120

Barrera, E. L., Spanjers, H., Romero, O., Rosa, E., \& Dewulf, J. (2014). Characterization of the sulfate reduction process in the anaerobic digestion of a very high strength and sulfate rich vinasse. Chemical Engineering Journal, 248, 383-393. https://doi.org/10.1016/j.cej.2014.03.057

Barton, L. L. (1995). Sulfate-Reducing Bacteria. (L. L. Barton, Ed.), Biotechnology handbooks: Sulfate-Reducing Bacteria - Volume 8. Boston, MA: Springer US. https://doi.org/10.1007/978-1-4899-1582-5

Barton, L. L., \& Hamilton, A. (2007). Sulphate-reducing Bacteria: environmental and engineered systems. (C. U. Press, Ed.). New York: Cambridge University Press.

Bertolino, S. M., Rodrigues, I. C. B., Guerra-Sá, R., Aquino, S. F., \& Leão, V. A. (2012). Implications of volatile fatty acid profile on the metabolic pathway during continuous sulfate reduction. Journal of Environmental Management, 103, 15-23. https://doi.org/10.1016/j.jenvman.2012.02.022

Buisman, C. J. N., Geraats, B. G., Ijspeert, P., \& Lettinga, G. (1990). Optimization of sulphur production in a biotechnological sulphide-removing reactor. Biotechnology and Bioengineering, 35(1), 50-56. https://doi.org/10.1002/bit.260350108 
Callado, N., Damianovic, M. H. R. Z., \& Foresti, E. (2015). Resilience of methanogenesis in an anaerobic reactor subjected to increasing sulfate and sodium concentrations. Journal of Water Process Engineering, 7, 203-209. https://doi.org/10.1016/j.jwpe.2015.06.011

Camiloti, P. R., Mockaitis, G., Domingues Rodrigues, J. A., Rissato Zamariolli Damianovic, M. H., Foresti, E., \& Zaiat, M. (2014). Innovative anaerobic bioreactor with fixedstructured bed (ABFSB) for simultaneous sulfate reduction and organic matter removal. Journal of Chemical Technology and Biotechnology, 89(7), 1044-1050. https://doi.org/10.1002/jctb.4199

Camiloti, P. R., Oliveira, G. H. D., \& Zaiat, M. (2016). Sulfur Recovery from Wastewater Using a Micro-aerobic External Silicone Membrane Reactor (ESMR). Water, Air, and Soil Pollution, 227(1), 31. https://doi.org/10.1007/s11270-015-2721-y

Cao, J., Zhang, G., Mao, Z. S., Li, Y., Fang, Z., \& Yang, C. (2012). Influence of electron donors on the growth and activity of sulfate-reducing bacteria. International Journal of Mineral Processing, 106-109, 58-64. https://doi.org/10.1016/j.minpro.2012.02.005

Carminato, V. M. (2013). Influência do cálcio na produção biológica de hidrogênio a partir de águas residuárias em biorreatores anaeróbios. Universidade de São Paulo.

CETESB. (2015). Norma técnica 4.231: Vinhaças - critérios e procedimentos para aplicação no solo agrícola. Companhia Ambiental do Estado de São Paulo.

Chen, C., Chen, H., Wu, J., \& Lin, C. (2008). Fermentative hydrogen production at high sulfate concentration. International Journal of Hydrogen Energy, 33(5), 1573-1578. https://doi.org/10.1016/j.ijhydene.2007.09.042

Chen, Y., Cheng, J. J. ., \& Creamer, K. S. . (2008). Inhibition of anaerobic digestion process: A review. Bioresource Technology, 99(10), 4044-4064. https://doi.org/10.1016/j.biortech.2007.01.057

Colleran, E., Finnegan, S., \& Lens, P. (1995). Anaerobic treatment of sulfate-containing waste streams. Antonie Van Leeuwenhoek International J, 67(1), 29-46. https://doi.org/10.1007/BF00872194

Dahar, B. R., Elbeshbishy, E., \& Nakhla, G. (2012). Influence of iron on sulfide inhibition in dark biohydrogen fermentation. Bioresouce Technology, 126, 123-130. https://doi.org/10.1016/j.biortech.2012.09.043

Damianovic, M. H. R. Z., Saia, F. T., de Godoi, L. A. G., \& Foresti, E. (2016). Long-term operation of anaerobic immobilized biomass reactor treating organic wastewater containing sulfate. Journal of Water Process Engineering, 13, 100-106. https://doi.org/10.1016/j.jwpe.2016.08.009

Damianovic, M. H. R. Z., Sakamoto, I. K., \& Foresti, E. (2006). Biofilm adaptation to sulfate reduction in anaerobic immobilized biomass reactors sujected to different COD/sulfate ratios. Water Science and Technology, 54(2), 119-126. https://doi.org/10.2166/wst.2006.494

Delée, W., O’Neill, C., Hawkes, F. R., \& Pinheiro, H. M. (1998). Review Anaerobic Treatment of Textile Effluents : a Review. J. Chem. Technol. Biotechnol., 73, 323-335.

DiLallo, R., \& Albertson, O. E. (1961). VOLATILE ACIDS BY DIRECT TITRATION. 
Water Environment Federation, 33(4), 356-365. https://doi.org//10.1590/0104$6632.20150321 \mathrm{~s} 00003024$

Dinopoulou, G., Rudd, T., \& Lester, J. N. (1988). Anaerobic acidogenesis of a complex wastewater: I. The influence of operational parameters on reactor performance. Biotechnology and Bioengineering, 31(9), 958-968. https://doi.org/10.1002/bit.260310908

Doble, M., \& Kumar, A. (2005). Biotreatment of Industrial Effluents. Elsevier. https://doi.org/10.1016/B978-0-7506-7838-4.X5000-3

Döll, M. M. R., \& Foresti, E. (2010). Efeito do bicarbonato de sódio no tratamento de vinhaça em AnSBBR operado a 55 e $35^{\circ}$ C. Engenharia Sanitaria E Ambiental, 15(3), 275-282.

Elia Neto, A. (2016). Estado da Arte da Vinhaça. Retrieved September 18, 2017, from http://www.unica.com.br/

Escudié, R., Cresson, R., Delgenès, J. P., \& Bernet, N. (2011). Control of start-up and operation of anaerobic biofilm reactors: An overview of 15 years of research. Water Research, 45(1), 1-10. https://doi.org/10.1016/j.watres.2010.07.081

Ferraz Jr., A. D. N., Koyama, M. H., Araújo, M. M. De, \& Zaiat, M. (2016). Thermophilic anaerobic digestion of raw sugarcane vinasse. Renewable Energy, 89, 245-252. https://doi.org/10.1016/j.renene.2015.11.064

Fuess, L. T., Araújo Jr., M. M. de, Garcia, M. L., \& Zaiat, M. (2017). Designing full-scale biodigestion plants for the treatment of vinasse in sugarcane biorefineries: How phase separation and alkalinization impact biogas and electricity production costs? Chemical Engineering Research and Design, 119, 209-220. https://doi.org/10.1016/j.cherd.2017.01.023

Fuess, L. T., Garcia, M. L., \& Zaiat, M. (2017). Seasonal characterization of sugarcane vinasse: Assessing environmental impacts from fertirrigation and the bioenergy recovery potential through biodigestion. Waste Manage.

Fuess, L. T., Kiyuna, L. S. M., Ferraz Jr., A. D. N., Felix, G. P., Marcio, F. S., Garcia, M. L., \& Zaiat, M. (2017). Thermophilic two-phase anaerobic digestion using an innovative fixed-bed reactor for enhanced organic matter removal and bioenergy recovery from $\begin{array}{lllll}\text { sugarcane } & \text { vinasse. } & \text { Applied } & \text { Energy, } & \text { 189, }\end{array}$ https://doi.org/10.1016/j.apenergy.2016.12.071

Fuess, L. T., Rodrigues, I. J., \& Garcia, M. L. (2017). Fertirrigation with sugarcane vinasse : Foreseeing potential impacts on soil and water resources through vinasse characterization. Journal of Environmental Science and Health, Part A, O(0), 1-10. https://doi.org/10.1080/10934529.2017.1338892

Garcia, C. G. (2014). Montagem e operação de unidade de adsorção em leito fixo para remoção de H2S de corrente gasosa. Universidade de São Paulo.

Gibson, G. R. (1990). Physiology and ecology of the sulphate-reducing bacteria. The Journal of Applied Bacteriology, 69(6), 769-797. https://doi.org/10.1111/j.13652672.1990.tb01575.x

Godoi, L. A. G. de, Foresti, E., \& Damianovic, M. H. R. Z. (2017). Down-flow fixed- 
structured bed reactor: An innovative reactor configuration applied to acid mine drainage treatment and metal recovery. Journal of Environmental Management, 197, 597-604. https://doi.org/10.1016/j.jenvman.2017.04.027

Godoi, L. A. G., Damianovic, M. H. R. Z., \& Foresti, E. (2015). Sulfidogenesis interference on methane production from carbohydrate-rich wastewater. Water Science and Technology, 72(9), 1644-1652. https://doi.org/10.2166/wst.2015.383

Hallenbeck, P. C., \& Ghosh, D. (2009). Advances in fermentative biohydrogen production: the way forward? Trends in Biotechnology, 27(5), 287-297. https://doi.org/10.1016/j.tibtech.2009.02.004

Hansen, T. A. (1993). Carbonmetabolism of sulfate-reducing bacteria. In The SulfateReducing Bacteria: Contemporary Perspectives (pp. 21-40). New York: SpringerVerlag.

Hao, T. W., Xiang, P. Y., Mackey, H. R., Chi, K., Lu, H., Chui, H. K., ... Chen, G. H. (2014). A review of biological sulfate conversions in wastewater treatment. Water Research, 65, 1-21. https://doi.org/10.1016/j.watres.2014.06.043

Harper, S. R., \& Pohland, F. G. (1986). Recent developments in hydrogen management during anaerobic biological wastewater treatment. Biotechnology and Bioengineering, 28(4), 585-602. https://doi.org/10.1002/bit.260280416

Hilton, B. L., \& Oleszkiewicz, J. a. (1988). Sulfide-Induced Inhibition of Anaerobic Digestion. Journal of Environmental Engineering, 114(6), 1377-1391. https://doi.org/10.1061/(ASCE)0733-9372(1988)114:6(1377)

Hwang, J.-H., Cha, G.-C., Jeong, T.-Y., Kim, D.-J., Bhatnagar, A., Min, B., ... Jeon, B. H. (2009). Effect of COD/SO42-ratio and $\mathrm{Fe}(\mathrm{II})$ under the variable hydraulic retention time (HRT) on fermentative hydrogen production. Water Research, 43(14), 3525-3533. https://doi.org/10.1016/j.watres.2009.04.023

Hwang, J.-H., Choi, J.-A., Abou-Shanab, R. A. I., Bhatnagar, A., Min, B., Song, H., ... Jeon, B. H. (2009). Effect of $\mathrm{pH}$ and sulfate concentration on hydrogen production using anaerobic mixed microflora. International Journal of Hydrogen Energy, 34(24), 97029710. https://doi.org/10.1016/j.ijhydene.2009.10.022

Hwang, J.-H., Choi, J.-A., Abou-Shanab, R. a. I., Bhatnagar, A., Min, B., Song, H., ... Kim, Y. J. (2009). Effect of $\mathrm{pH}$ and sulfate concentration on hydrogen production using anaerobic mixed microflora. International Journal of Hydrogen Energy, 34(24), 97029710. https://doi.org/10.1016/j.ijhydene.2009.10.022

Hwang, J.-H., Choi, J.-A., Oh, Y.-K., Abou-Shanab, R. a. I., Song, H., Min, B., ... Jeon, B.H. (2011). Hydrogen production from sulfate- and ferrous-enriched wastewater. International Journal of Hydrogen Energy, 36(21), 13984-13990. https://doi.org/10.1016/j.ijhydene.2011.03.156

Infantes, D., González Del Campo, A., Villaseñor, J., \& Fernández, F. J. (2011). Influence of $\mathrm{pH}$, temperature and volatile fatty acids on hydrogen production by acidogenic fermentation. International Journal of Hydrogen Energy, 36(24), 15595-15601. https://doi.org/10.1016/j.ijhydene.2011.09.061

Janssen, A. J. H., Sleyster, R., van der Kaa, C., Jochemsen, A., Bontsema, J., \& Lettinga, G. 
(1995). Biological sulphide oxidation in a fed-batch reactor. Biotechnology and Bioengineering, 47(3), 327-333. https://doi.org/10.1002/bit.260470307

Jing, C., Ping, Z., \& Mahmood, Q. (2010). Influence of various nitrogenous electron acceptors on the anaerobic sulfide oxidation. Bioresource Technology, 101(9), 29312937. https://doi.org/10.1016/j.biortech.2009.11.047

Kiyuna, L. S. M., Fuess, L. T., \& Zaiat, M. (2017). Unraveling the influence of the $\mathrm{COD} /$ sulfate ratio on organic matter removal and methane production from the biodigestion of sugarcane vinasse. Bioresource Technology, 232, 103-112. https://doi.org/10.1016/j.biortech.2017.02.028

Koschorreck, M. (2008). Microbial sulphate reduction at a low pH. FEMS Microbiology Ecology, 64(3), 329-342. https://doi.org/10.1111/j.1574-6941.2008.00482.x

Lata, K., Kansal, A., Balakrishnan, M., Rajeshwari, K. V., \& Kishore, V. V. N. (2002). Assessment of biomethanation potential of selected industrial organic effluents in India. Resources, Conservation and Recycling, 35(3), 147-161. https://doi.org/10.1016/S09213449(01)00112-4

Lebrero, R., Toledo-Cervantes, A., Muñoz, R., del Nery, V., \& Foresti, E. (2016). Biogas upgrading from vinasse digesters: a comparison between an anoxic biotrickling filter and an algal-bacterial photobioreactor. Journal of Chemical Technology and Biotechnology, 91(9), 2488-2495. https://doi.org/10.1002/jctb.4843

Leme, R. M., \& Seabra, J. E. A. (2017). Technical-economic assessment of different biogas upgrading routes from vinasse anaerobic digestion in the Brazilian bioethanol industry. Energy, 119, 754-766. https://doi.org/10.1016/j.energy.2016.11.029

Lens, P. N. L., Visser, a., Janssen, a. J. H., Pol, L. W. H., \& Lettinga, G. (1998). Biotechnological Treatment of Sulfate-Rich Wastewaters. Critical Reviews in Environmental Science and Technology, 28(1), 41-88. https://doi.org/10.1080/10643389891254160

Liamleam, W., \& Annachhatre, A. P. (2007). Electron donors for biological sulfate reduction. Biotechnology Advances, 25(5), 452-463. https://doi.org/10.1016/j.biotechadv.2007.05.002

Lin, C. Y., \& Chen, H. P. (2006). Sulfate effect on fermentative hydrogen production using anaerobic mixed microflora. International Journal of Hydrogen Energy, 31(7), 953-960. https://doi.org/10.1016/j.ijhydene.2005.07.009

Lohwacharin, J., \& Annachhatre, A. P. (2010). Biological sulfide oxidation in an airlift bioreactor. Bioresource Technology, 101(7), 2114-2120. https://doi.org/10.1016/j.biortech.2009.10.093

Lopes, S. I. C., Wang, X., Capela, M. I., \& Lens, P. N. L. (2007). Effect of COD/SO42- ratio and sulfide on thermophilic (55 ??C) sulfate reduction during the acidification of sucrose at $\mathrm{pH}$ 6. Water Research, 41(11), 2379-2392. https://doi.org/10.1016/j.watres.2007.02.023

Luo, G., Xie, L., Zhou, Q., \& Angelidaki, I. (2011). Enhancement of bioenergy production from organic wastes by two-stage anaerobic hydrogen and methane production process. Bioresource 
https://doi.org/10.1016/j.biortech.2011.02.012

Maillacheruvu, K. Y., Parkin, G. F., Peng, C. Y., Kuo, W., Oonge, Z. I., \& Lebduschka, V. (1993). Sulfide Toxicity in Anaerobic Systems Fed Sulfate and Various Organics. Water Environment Research, 65(2), 100-109. https://doi.org/10.2175/WER.65.2.2

Martins, M., \& Pereira, I. a. C. (2013). Sulfate-reducing bacteria as new microorganisms for biological hydrogen production. International Journal of Hydrogen Energy, 38(28), 12294-12301. https://doi.org/10.1016/j.ijhydene.2013.07.044

McCartney, D. M., \& Oleszkiewicz, J. A. (1993). Competition between methanogens and sulfate recucers: effect of COD:sulfate ratio and acclimation. Water Environment Reserch, 65(5), 655-664. https://doi.org/https://doi.org/10.2175/WER.65.5.8

Metcalf, \& Eddy. (2016). Tratamento de Efluentes e Recuperação de Recursos. (A. E. LTDA, Ed.) (5th ed.).

Michaud, S., Bernet, N., Buffière, P., Roustan, M., \& Moletta, R. (2002). Methane yield as a monitoring parameter for the start-up of anaerobic fixed film reactors. Water Research, 36(5), 1385-1391. https://doi.org/10.1016/S0043-1354(01)00338-4

Mizuno, O., Li, Y. Y., \& Noike, T. (1998). THE BEHAVIOR OF SULFATE-REDUCING BACTERIA IN ACIDOGENIC PHASE OF ANAEROBIC DIGESTION, 32(5), 16261634.

Moraes, B. S., Souza, T. S. O., \& Foresti, E. (2012). Effect of sulfide concentration on autotrophic denitrification from nitrate and nitrite in vertical fixed-bed reactors. Process Biochemistry, 47(9), 1395-1401. https://doi.org/10.1016/j.procbio.2012.05.008

Muñoz, R., Meier, L., Diaz, I., \& Jeison, D. (2015). A review on the state-of-the-art of physical/chemical and biological technologies for biogas upgrading. Reviews in Environmental Science and Biotechnology, 14(4), 727-759. https://doi.org/10.1007/s11157-015-9379-1

Muthaiyan, A., Limayem, A., \& Ricke, S. C. (2011). Antimicrobial strategies for limiting bacterial contaminants in fuel bioethanol fermentations. Progress in Energy and Combustion Science, 37(3), 351-370. https://doi.org/10.1016/j.pecs.2010.06.005

Muyzer, G., \& Stams, A. J. M. (2008). The ecology and biotechnology of sulphate-reducing bacteria. Nature, 6(june), 441-454. https://doi.org/10.1038/nrmicro1892

Nagpal, S., Chuichulcherm, S., Livingston, A., \& Peeva, L. (2000). Ethanol utilization by sulfate-reducing bacteria: An experimental and modeling study. Biotechnology and Bioengineering, $\quad 70(5), \quad$ 533-543. $\mathrm{https} / / / \mathrm{doi} .0 \mathrm{rg} / 10.1002 / 1097$ 0290(20001120)70:4<370::AID-BIT2>3.0.CO;2-7

Oliva-Neto, P. de, Dorta, C., Carvalho, A. F. A., Lima, V. M. G. de, \& Silva, D. F. da. (2013). The Brazilian technology of fuel ethanol fermentation - yeast inhibition factors and new perspectives to improve the technology. Materials and Process Fr Energy: Communicating Current Research and Technological Development, 371-379.

Overmeire, A., Lens, P., \& Verstraete, W. (1994). Mass transfer limitation of sulfate in methanogenic aggregates. Biotechnology and Bioengineering, 44(3), 387-391. https://doi.org/10.1002/bit.260440318 
Parkin, G. F., Lynch, N. A., Kuo, W., Keuren, E. L. Van, \& Bhattacharya, S. K. (1990). Interaction between sulfate reducers and methanogens fed acetate and propionate. Water Environment Federation, 62(6), 780-788.

Parkin, G. F., \& Speece, R. E. (1983). Attached versus suspended growth anaerobic reactors: Response to toxic substances. Water Science and Technology, 15(8-9), 261-289.

Pender, S., Toomey, M., Carton, M., Eardly, D., Patching, J. W., Colleran, E., \& O'Flaherty, V. (2004). Long-term effects of operating temperature and sulphate addition on the methanogenic community structure of anaerobic hybrid reactors. Water Research, 38(3), 619-630. https://doi.org/10.1016/j.watres.2003.10.055

Penteado, E. D. (2016). TRATAMENTO DE ÁGUA RESIDUÁRIA EM CÉLULA COMBUSTÍVEL MICROBIANAS E GERAÇÃO DE ENERGIA ELÉTRICA DIRETA: FUNDAMENTOS E APLICAÇÃO. Universidade de São Paulo.

Pérez, M., Romero, L. I., \& Sales, D. (1998). COMPARATIVE PERFORMANCE OF HIGH RATE ANAEROBIC THERMOPHILIC TECHNOLOGIES TREATING INDUSTRIAL WASTEWATER. Water Research, 32(3), 559-564.

Perna, V., Castelló, E., Wenzel, J., Zampol, C., Fontes Lima, D. M., Borzacconi, L., ... Etchebehere, C. (2013). Hydrogen production in an upflow anaerobic packed bed reactor used to treat cheese whey. International Journal of Hydrogen Energy, 38(1), 54-62. https://doi.org/10.1016/j.ijhydene.2012.10.022

Plugge, C. M., Zhang, W., Scholten, J. C. M., \& Stams, A. J. M. (2011). Metabolic flexibility of sulfate-reducing bacteria. Frontiers in Microbiology, 2(MAY), 1-8. https://doi.org/10.3389/fmicb.2011.00081

Pokhrel, D., \& Viraraghavan, T. (2004). Treatment of pulp and paper mill wastewater - a review. Science of the Total Environment, The, 333(1-3), 37-58.

Polo, B. C., Bewtra, N., \& Biswas, N. (2006). Effect of hydraulic retention time and attachment media on sulfide production by sulfate reducing bacteria. Journal of Environmental Engineering and Science, 5(1), 47-57. https://doi.org/10.1139/s05-013

Rajeshwari, K. V, Balakrishnan, M., Kansal, A., Lata, K., \& Kishore, V. V. N. (2000). Stateof-the-art of anaerobic digestion technology for industrial wastewater treatment. Renewable and Sustainable Energy Reviews, 4, 135-156.

Reis, M. A. M., Gonçalves, L. M. D., \& Carrondo, M. J. T. (1988). Sulfate reduction in acidogenic phase anaerobic digestion. Water Science \& Technology, 20(11-12), 345351. https://doi.org/10.1080/09593338809384632

Reis, M. A. M., Lemos, P. C., Martins, M. J., Costa, P. C., Gonçalves, L. M. D., \& Carrondo, M. J. . T. (1991). Influence of sulfates and operational parameters on volatile fatty acids concentration profile in acidogenic phase. Bioprocess Engineering, 6(4), 145-151. https://doi.org/10.1007/BF00369251

Ribas, M. M. F., Chinalia, F. A., Pozzi, E., \& Foresti, E. (2009). Microbial succession within an Anaerobic Sequencing Batch Biofilm Reactor (ASBBR) treating cane vinasse at $55^{\circ} \mathrm{C}$. Brazilian Archives of Biology and Technology, 52(4), 1027-1036. https://doi.org/10.1590/S1516-89132009000400028 
Rio, S., Faur-Brasquet, C., Le Coq, L., \& Le Cloirec, P. (2005). Structure characterization and adsorption properties of pyrolyzed sewage sludge. Environmental Science \& Technology, 39, 4249-4257. Retrieved from http://www.ncbi.nlm.nih.gov/pubmed/15984807

Ripley, A. L. E., Boyle, W. C., \& Converse, J. C. (1986). Improved alkalimetric monitoring for anaerobic digestion of high-strength wastes. Water Pollution Contron Federation, $58(5), 406-411$.

Rodriguez, R. P., Oliveira, G. H. D., Raimundi, I. M., \& Zaiat, M. (2012). Assessment of a UASB reactor for the removal of sulfate from acid mine water. International Biodeterioration \& Biodegradation, 48 48-53. https://doi.org/10.1016/j.ibiod.2012.07.012

Saady, N. M. C. (2013). Homoacetogenesis during hydrogen production by mixed cultures dark fermentation: Unresolved challenge. International Journal of Hydrogen Energy, 38(30), 13172-13191. https://doi.org/10.1016/j.ijhydene.2013.07.122

Sakamoto, I. K., Maintinguer, S. I., Hirasawa, J. S., Adorno, M. A. T., \& Varesche, M. B. A. (2012). Evaluation of microorganisms with sulfidogenic metabolic potential under anaerobic conditions. Brazilian Archives of Biology and Technology, 55(5), 779-784. https://doi.org/10.1590/S1516-89132012000500018

Sakamoto, I. K., Pozzi, E., Del Nery, V., Okada, D. Y., \& Varesche, M. B. A. (2016). Microbial community characterization of granulated sludge from UASB reactors ( fullscale ) used in poultry slaughterhouse wastewater treatment systems by Illumina Miseq sequencing (p. 11). Cusco.

Santos, S. C., Rosa, P. R. F., Sakamoto, I. K., Varesche, M. B. A., \& Silva, E. L. (2014). Continuous thermophilic hydrogen production and microbial community analysis from anaerobic digestion of diluted sugar cane stillage. International Journal of Hydrogen Energy, 39(17), 9000-9011. https://doi.org/10.1016/j.ijhydene.2014.03.241

Show, K. Y., Lee, D. J., Tay, J. H., Lin, C. Y., \& Chang, J. S. (2012). Biohydrogen production: Current perspectives and the way forward. International Journal of Hydrogen Energy, 37(20), 15616-15631. https://doi.org/10.1016/j.ijhydene.2012.04.109

Silva, A. J., Hirasawa, J. . S., Varesche, M. . B., Foresti, E., \& Zaiat, M. . (2006a). Evaluation of support materials for the immobilization of sulfate-reducing bacteria and methanogenic archaea, 12, 93-98. https://doi.org/10.1016/j.anaerobe.2005.12.003

Silva, A. J., Hirasawa, J. S., Varesche, M. B., Foresti, E., \& Zaiat, M. (2006b). Evaluation of support materials for the immobilization of sulfate-reducing bacteria and methanogenic archaea. Anaerobe, 12(2), 93-98. https://doi.org/10.1016/j.anaerobe.2005.12.003

Speece, R. E. (1996). Anaerobic biotechnology for industrial wastewaters. Tennesee - USA: Archae press.

Syutsubo, K., Harada, H., Ohashi, A., \& Suzuki, H. (1997). An effective start-up of thermophilic UASB reactor by seeding mesophilically-grown granular sludge. Water Science and Technology, 36(6-7), 391-398. https://doi.org/10.1016/S02731223(97)00547-7

Tang, Y. Q., An, M. Z., Zhong, Y. L., Shigeru, M., Wu, X. L., \& Kida, K. (2010). Continuous ethanol fermentation from non-sulfuric acid-washed molasses using traditional stirred 
tank reactors and the flocculating yeast strain KF-7. Journal of Bioscience and Bioengineering, 109(1), 41-46. https://doi.org/10.1016/j.jbiosc.2009.07.002

Thauer, R. K., Jungermann, K., \& Decker, K. (1977). Energy conservation in chemotrophic anaerobic bacteria. Bacteriological Reviews, 41(1), 100-180. https://doi.org/10.1073/pnas.0803850105

Torres, P. (1992). Desempenho de um reator anaeróbio de manta de lodo (UASB) de bancada no tratamento de substrato sintético simulando esgotos sanitários. Universidade de São Paulo.

Touzel, J. P., \& Albagnac, G. (1983). Isolation and characterization of methanococcusmazei strain MC3. FEMS Microb. Lett, 16(2-3), 241-245.

Van Houten, R. T., Hulshoff Pol, L. W., \& Lettinga, G. (1994). Biological sulphate reduction using gas-lift reactors fed with hydrogen and carbon dioxide as energy and carbon source. Biotechnology and Bioengineering, 44(5), 586-594. https://doi.org/10.1002/bit.260440505

Vavilin, V. A., Vasiliev, V. B., Rytov, S. V, \& Ponomarev, A. V. (1994). Self-oscillating coexistence of methanogens and sulfate-reducers under hydrogen sulfide inhibition and the pH-regulating effect. Bioresource Technology, 49, 105-119.

Viñas, M., Martínez, J., \& Basell, B. (1993). Advantages of an anaerobic reactor for tmp wastewater with separated acidogenic and methanogenic stages. Environmental Technology, 14(10), 995-1000. https://doi.org/10.1080/09593339309385375

Widdel, F. (1988). Microbiology and ecology of sulphate-and sulphur reducing bacteria. In Biology of Anaerobic MIcroorganisms (pp. 469-586). New York: Wiley \& Sons.

Yu, H. Q., Fang, H. H. P., \& Gu, G. W. (2002). Comparative performance of mesophilic and thermophilic acidogenic upflow reactors. Process Biochemistry, 38(3), 447-454. https://doi.org/10.1016/S0032-9592(02)00161-9

Yurtsever, A., Çinar, Ö., \& Sahinkaya, E. (2016). Treatment of textile wastewater using sequential sulfate-reducing anaerobic and sulfide-oxidizing aerobic membrane bioreactors. Journal of Membrane Science, 511, 228-237. https://doi.org/10.1016/j.memsci.2016.03.044

Zeng, Q., Hao, T., Mackey, H. R., Wei, L., \& Guo, G. (2017). Alkaline textile wastewater biotreatment: A sulfate-reducing granular sludge based lab-scale study. Journal of Hazardous Materials, 332, 104-111. https://doi.org/10.1016/j.jhazmat.2017.03.005

Zhang, Z. Y., \& Maekawa, T. (1996). EFFECTS OF SULFUR-CONTAINING COMPOUNDS ON ACCLIMATED-MIXED. Biomass and Bioenergy, 10(I), 45-56.

Zhao, Y., Ren, N., \& Wang, A. (2008). Contributions of fermentative acidogenic bacteria and sulfate-reducing bacteria to lactate degradation and sulfate reduction. Chemosphere, 72(2), 233-242. https://doi.org/10.1016/j.chemosphere.2008.01.046

Zhou, J., \& Xing, J. (2015). Effect of electron donors on the performance of haloalkaliphilic sulfate-reducing bioreactors for flue gas treatment and microbial degradation patterns related to sulfate reduction of different electron donors. Biochemical Engineering Journal, 96, 14-22. https://doi.org/10.1016/j.bej.2014.12.015 
